Review

\title{
Cancer Chemopreventive Role of Dietary Terpenoids by Modulating Keap1-Nrf2-ARE Signaling System-A Comprehensive Update
}

\author{
Md Afjalus Siraj ${ }^{1, *(D)}$, Md. Arman Islam ${ }^{2}$, Md. Abdullah Al Fahad ${ }^{3}$, Habiba Rahman Kheya ${ }^{4}$, Jianbo Xiao ${ }^{5}$ \\ and Jesus Simal-Gandara $5, *$ (D)
}

1 Department of Pharmaceutical Sciences, Daniel K. Inouye College of Pharmacy, University of Hawaii at Hilo, Hilo, HI 96720, USA

2 Pharmacy Discipline, Life Science School, Khulna University, Khulna 9208, Bangladesh; armanislamkupharm@gmail.com

3 Department of Regenerative Medicine, College of Medicine, Soonchunhyang University, Cheonan 31151, Korea; saykat0047@gmail.com

4 Department of Sociology, Faculty of Social Sciences, University of Dhaka, Dhaka 1000, Bangladesh; habibarahmankheya@gmail.com

5 Nutrition and Bromatology Group, Department of Analytical and Food Chemistry, Faculty of Food Science and Technology, University of Vigo-Ourense Campus, E32004 Ourense, Spain; jianboxiao@uvigo.es

* Correspondence: afjalus.siraj@gmail.com (M.A.S.); jsima@uvigo.es (J.S.-G.)

check for updates

Citation: Siraj, M.A.; Islam, M.A.; Al Fahad, M.A.; Kheya, H.R.; Xiao, J.; Simal-Gandara, J. Cancer Chemopreventive Role of Dietary Terpenoids by Modulating Keap1-Nrf2-ARE Signaling System-A Comprehensive Update. Appl. Sci. 2021, 11, 10806. https:// doi.org/10.3390/app112210806

Academic Editor: David Mills

Received: 4 September 2021

Accepted: 13 November 2021

Published: 16 November 2021

Publisher's Note: MDPI stays neutral with regard to jurisdictional claims in published maps and institutional affiliations.

Copyright: (c) 2021 by the authors. Licensee MDPI, Basel, Switzerland. This article is an open access article distributed under the terms and conditions of the Creative Commons Attribution (CC BY) license (https:/ / creativecommons.org/licenses/by/ $4.0 /)$.

\begin{abstract}
ROS, RNS, and carcinogenic metabolites generate excessive oxidative stress, which changes the basal cellular status and leads to epigenetic modification, genomic instability, and initiation of cancer. Epigenetic modification may inhibit tumor-suppressor genes and activate oncogenes, enabling cells to have cancer promoting properties. The nuclear factor erythroid 2-related factor 2 (Nrf2) is a transcription factor that in humans is encoded by the NFE2L2 gene, and is activated in response to cellular stress. It can regulate redox homoeostasis by expressing several cytoprotective enzymes, including NADPH quinine oxidoreductase, heme oxygenase-1, UDP-glucuronosyltransferase, glutathione peroxidase, glutathione-S-transferase, etc. There is accumulating evidence supporting the idea that dietary nutraceuticals derived from commonly used fruits, vegetables, and spices have the ability to produce cancer chemopreventive activity by inducing Nrf2-mediated detoxifying enzymes. In this review, we discuss the importance of these nutraceuticals in cancer chemoprevention and summarize the role of dietary terpenoids in this respect. This approach was taken to accumulate the mechanistic function of these terpenoids to develop a comprehensive understanding of their direct and indirect roles in modulating the Keap1-Nrf2-ARE signaling system.
\end{abstract}

Keywords: Keap1; Nrf2; ARE; terpenoid; cancer; chemoprevention; reactive oxygen species (ROS)

\section{Introduction}

Today, cancer is considered one of the major global health crises. It is the second most prominent cause of death in the United States [1]. Globally, the cancer burden is estimated to double over the upcoming two decades [2]. This increasing global cancer incidence, associated with mortality along with spiraling treatment costs, is gradually increasing the interest in cancer prevention. Therefore, the FDA has approved several drugs for chemoprevention to minimize cancer incidence, morbidity, and mortality in the upcoming years [3]. In addition, it has been evidenced that an efficiently healthy diet containing plant-based foods with reduced intake of high-calorie meals, red meat, processed meat, etc., can contribute to chemoprevention [4]. Chemoprevention is a promising approach against a wide range of cancers for reversing, restraining or preventing different stages of carcinogenesis through the use of dietary supplements, as well as drugs from nature or synthetic sources [5]. 
Cancer chemopreventive agents are generally divided into two groups. First, blocking agents, which inhibit the mutagenic initiation of the carcinogenic activity, and second, suppressing agents, which inhibit the further advancement of an existing lesion [6]. Some agents are included in both categories. In addition, blocking agents are again sub-classified into three groups on the basis of their mechanism of action. The first group acts simply by preventing the activation of a carcinogen into its potential carcinogenic form, i.e., prevention of symmetrical dimethylhydrazine-induced neoplasia by disulfiram. The second group increases the activity of the enzyme systems involving the carcinogen detoxification process. The members of the third group act by scavenging and neutralizing the reactive forms of carcinogens, e.g., physiological nucleophile glutathione (GSH) [6]. Popularly known chemopreventive agents, e.g., traditional Chinese medicines, natural compounds, FDA approved drugs, etc., are selective and predisposed to interact with various protein targets with varied signaling pathways in living cells [7]. An increasing amount of evidence is accumulating in which cancer patients have been administered herbs using complementary therapies or dietary components that remarkably interfere with cell signaling [8]. Therefore, chemoprevention is effective with a molecular-level understanding of the factors that initiate and trigger cancer [9].

Over the last several decades, an increasing amount of focus has been put on the molecular origins of cancer. Reactive oxygen species (ROS) are greatly responsible for cancer development, either initiating tumor formation or facilitating cancer cell proliferation [10]. Specifically, increased ROS production accompanies hyperproliferation of tumor cells, and this process is aggravated when oxidative stress hampers the redox balance. Invasive tumor cells achieve this state by enhancing their antioxidant level to help ROSmediated proliferation, while simultaneously evading ROS thresholds that would facilitate apoptosis, senescence, and ferroptosis [11,12]. Therefore, cancer cell proliferation can be managed through ROS modulation. The kelch like ECH associated protein 1 (Keap1)nuclear factor erythroid 2-related factor 2 (Nrf2)-antioxidant response element (ARE) signaling safeguards cells from carcinogenic invasion and restricts cancer development via ROS neutralization [13]. It has been observed in several studies that the Keap1-Nrf2 pathway is mutated in various cancers [14]. During oxidative stress, Nrf2 dissociates from Keap1 to be translocated into the nucleus; in turn, nuclear Nrf2 upregulates ARE-associated gene expression, i.e., heme oxygenase-1 (HO-1), NAD(P)H quinine oxidoreductase (NQO1), glutamate-cysteine ligase (GCL), GSH, GSH peroxidase (Gpx), etc., to maintain the cellular redox homeostasis [15]. As polyphenols from dietary sources are widely known for tackling oxidative stress, modulation of Keap1-Nrf2-ARE signaling by some of these compounds is expected to bring benefits in the prevention of oxidative-stress-mediated cancers.

Certain phytochemicals including dietary constituents that can decrease tumorigenesis both in vitro and in vivo experimental models. It has been well-established that the intake of these phytochemicals can either prevent cancer or slow down its growth and progression [16]. They play these roles either by decreasing metabolic activation of carcinogen, increasing the detoxification of carcinogens, or preventing them from binding with their cellular targets. Figure 1 demonstrates how certain groups of dietary nutraceuticals have been recognized or are thought to modulate specific pathways causing breast cancer development. This evidence, as well as additional information on naturally occurring food constituents and vitamins, has established the idea that diet modification can play vital role to prevent cancer [17].

Terpenoids, present largely in plants, animals, fungi and microbial species, are known for exhibiting potential effectivity against cancers [18]. For example, betulinic acid, a triterpene compound extracted from birch tree, has shown cytotoxic activity in multiple cancer cells $[19,20]$. The cancer suppressing properties of terpenoids include inhibition of cell adhesion, migration and proliferation, specifically observed for a novel diterpene, tanshinone [21]. Limonene, a monoterpene, can be deposited in the fatty tissues due to its lipophilic nature in order to produce a long-term chemopreventive effect by mediating cell cycle arrest and eventually apoptosis [22]. Recently, multiple terpenoid compounds 
have been found to be effective in activating the Keap1-Nrf2-ARE pathway, where the downstream target genes of Nrf2 were enhanced in a process that involved phosphoinositide 3-kinases (PI3K), protein kinase C (PKC), etc., [23]. In this review, we summarize the information of dietary terpenoids demonstrating a cancer chemopreventive role by direct or indirect modulation of the Keap1-Nrf2-ARE signaling system. The chemopreventive mechanisms of the associated up- and downstream signaling molecules of Keap1-Nrf2-ARE signaling are also discussed.

\section{Terpenoids}

Terpenoids, also known as terpenes, are the largest group of phytochemicals, and are present in many different plants, playing an array of biological and biochemical roles within living systems. Green plants, especially flowering plants, possess an incredibly large number of terpenoid compounds in comparison with other living organisms [24]. More than 80 thousand terpenoid secondary metabolites have been isolated from different sources in nature [25]. However, interestingly, there are a few hundred terpenoids that are present in almost all plant species, which are designated as primary metabolites and are involved in several biological activities, such as antioxidant, electron transfer, hormone and protein modification, membrane fluidity determination, etc., [24]. 'Terpenoids' are organic compounds commonly known as hydrocarbons. Their oxygenated, hydrogenated and dehydrogenated derivatives contain the general formula of $\left(\mathrm{C}_{5} \mathrm{H}_{8}\right) n$, where ' $n$ ' suggests the number of isoprene units [26]. Natural products containing terpenoids are rich in "isopentenyl pyrophosphate", which is the active isoprene unit present in almost all living organisms as a common biosynthetic origin [27]. They are commonly classified as monoterpenoids $\left(C_{10}\right)$, sesquiterpenoids $\left(C_{15}\right)$, diterpenoids $\left(C_{20}\right)$, sesterterpenoids $\left(C_{25}\right)$, triterpenoids $\left(\mathrm{C}_{30}\right)$, tetraterpenoids $\left(\mathrm{C}_{40}\right)$, and polyterpenoids. Mono-, sesqui-, di-, tri-, and tetraterpenes are composed of two, three, four, six, and eight isoprene units, respectively.

The unique structural diversity of terpenoids is employed in coupling chemistry, which essentially links $C_{5}$ isoprenoid precursors; $C_{5}$ dimethylallyl diphosphate and $C_{5}$ isopentenyl diphosphate become linked in a regular manner to generate $C_{10}$ geranyl diphosphate (GPP), which can be condensed with supplementary isopentenyl diphosphate entities to generate $\mathrm{C}_{15}$ farnesyl diphosphate (FPP), $\mathrm{C}_{20}$ geranylgeranyl pyrophosphate (GGPP), and $\mathrm{C}_{25}$ geranylfarnesyl diphosphate, and this process continues [25]. For monoterpene synthesis, a distinct presence of geranyl pyrophosphate synthase enzyme is found in plants, although this enzyme is present in very low amounts in animals [28]. Terpene cyclases act directly on GPP, FPP and GGPP to yield mono-, sesqui-, and diterpenes; "head-to-head" linkage between FPP and GGPP yields tri- and tetraterpene presqualene diphosphate and prephytoene diphosphate, respectively [29]. Within human physiological systems, the formation of these important terpene metabolites is significant for cellular protein modification through the process of glycosylation and energy generation [30,31].

Several epidemiological studies have suggested that increased intakes of vegetables, fruits, whole-grains and pulses, and reduced intakes of red and processed meats and salt, are associated with minimized cancer risk [32]. As daily diets are responsible for the pathogenesis of multiple cancers, diets rich in plant-derived secondary metabolites can support the prevention of cancers. Terpenoids have been reported to possess several pharmacological activities, including against cancer (i.e., taxanes from Taxus brevifolia and vincristine and vinblastine from Catharanthus roseus) [33,34], malaria (i.e., artemisinin from Artemisia annua), and HIV (i.e., calanolide A from Calophyllum lanigerum) [35], etc., In particular, in the case of breast cancer development, terpenoids play chemopreventive roles by abrogating cancer initiation, promotion, and oxidative damage (Figure 1). Some terpenoid pigments including astaxanthin, bixin, and lycopene are widely used in various food industries. Additionally, the human body uses some of the terpenoids to yield essential compounds; for example, vitamin A is synthesized from $\beta$-carotene, a widely known plant terpene. The list and structures of dietary terpenes that modulate the Keap1- 
Nrf2-ARE system are mentioned below, along with their chemical class (Table 1, Figure 2).

The common dietary sources of these terpenes are listed as well (Table 2).

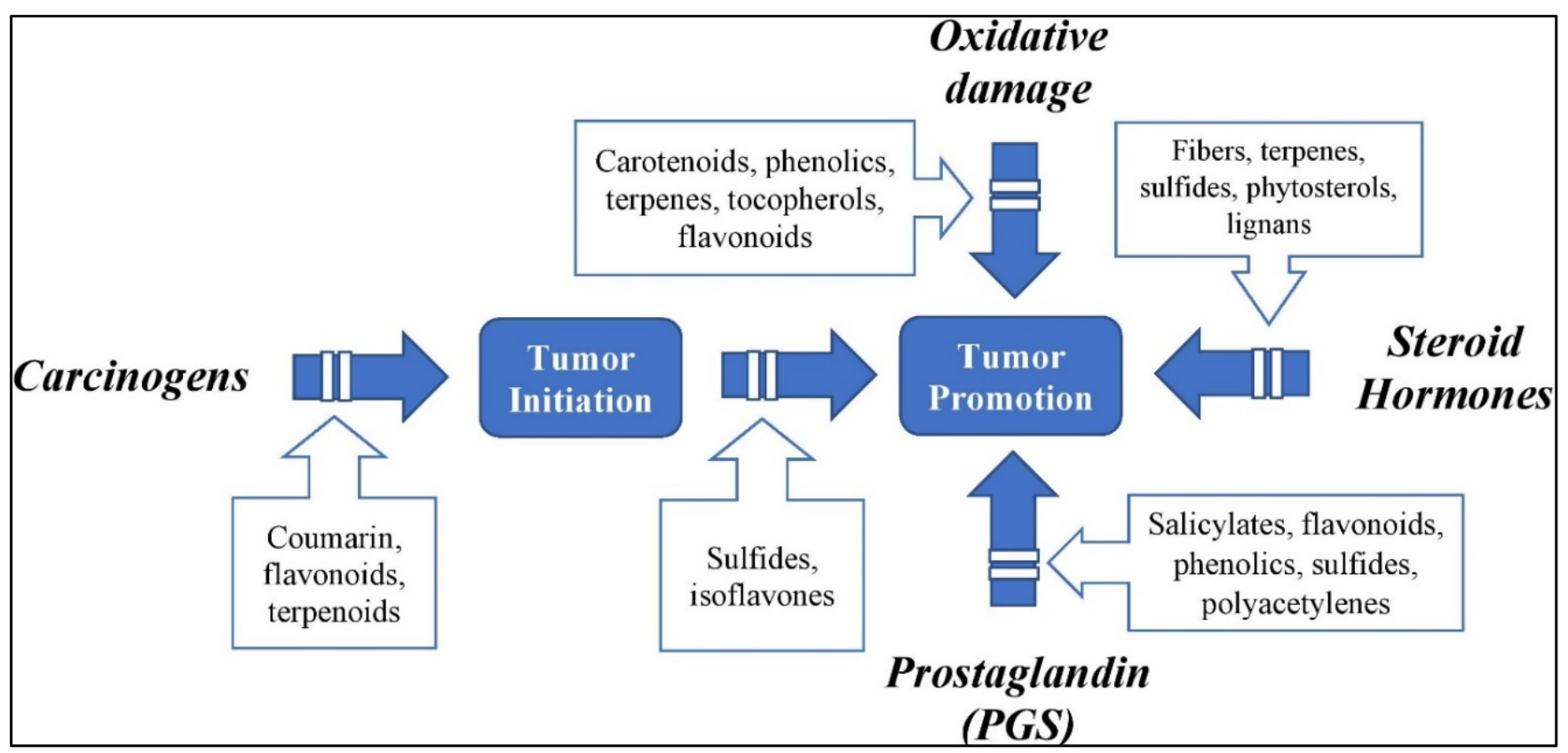

Figure 1. Nutraceuticals can alter and inhibit the specific cellular and metabolic pathways associated with breast cancer development [36-38].

Table 1. Dietary terpenoid phytochemicals which can modulate the Keap1-Nrf2-ARE signaling system and their chemical classes.

\begin{tabular}{ccccc}
\hline $\begin{array}{c}\text { Compound } \\
\text { Number }\end{array}$ & Compound Name & $\begin{array}{c}\text { Chemical } \\
\text { Formula }\end{array}$ & $\begin{array}{c}\text { Sub-Chemical } \\
\text { Class }\end{array}$ & $\begin{array}{c}\text { Major Chemical } \\
\text { Class }\end{array}$ \\
\hline $\mathbf{1}$ & Zerumbone & $\mathrm{C}_{15} \mathrm{H}_{22} \mathrm{O}$ & $\begin{array}{c}\text { Sesquiterpenoid } \\
\text { Andirobin-type } \\
\text { limonoid }\end{array}$ & Sesquiterpenoid \\
$\mathbf{2}$ & Khayandirobilide A & $\mathrm{C}_{22} \mathrm{H}_{27} \mathrm{O}_{11}$ & Triterpenoid \\
& Quassinoid & Triterpenoid \\
$\mathbf{3}$ & Brusatol & $\mathrm{C}_{26} \mathrm{H}_{32} \mathrm{O}_{11}$ & compound & Triterpenoid \\
$\mathbf{4}$ & Withaferin A & $\mathrm{C}_{28} \mathrm{H}_{38} \mathrm{O}_{6}$ & Steroid & Triterpenoid \\
$\mathbf{5}$ & Betulin & $\mathrm{C}_{30} \mathrm{H}_{50} \mathrm{O}_{2}$ & Steroid & Triterpenoid \\
$\mathbf{6}$ & Ganodermanondiol & $\mathrm{C}_{30} \mathrm{H}_{48} \mathrm{O}_{3}$ & Steroid & Triterpenoid \\
$\mathbf{7}$ & Oleanolic acid & $\mathrm{C}_{30} \mathrm{H}_{48} \mathrm{O}_{3}$ & Steroid & Triterpenoid \\
$\mathbf{8}$ & Ursolic acid & $\mathrm{C}_{30} \mathrm{H}_{48} \mathrm{O}_{3}$ & Steroid & Triterpenoid \\
$\mathbf{9}$ & Dioscin & $\mathrm{C}_{45} \mathrm{H}_{72} \mathrm{O}_{16}$ & Saponin & Triterpene acid \\
$\mathbf{1 0}$ & Corosolic acid & $\mathrm{C}_{30} \mathrm{H}_{48} \mathrm{O}_{4}$ & Steroid & Tetraterpenoid \\
$\mathbf{1 1}$ & Lycopene & $\mathrm{C}_{40} \mathrm{H}_{56}$ & Carotenoid & Tetraterpenoid \\
$\mathbf{1 2}$ & Astaxanthin & $\mathrm{C}_{40} \mathrm{H}_{52} \mathrm{O}_{4}$ & Carotenoid & Tetraterpenoid \\
$\mathbf{1 3}$ & Fucoxanthin & $\mathrm{C}_{42} \mathrm{H}_{58} \mathrm{O}_{6}$ & Carotenoid & Tetrid \\
\hline
\end{tabular}

Table 2. Common dietary sources of terpenoid phytochemicals that can modulate the Keap1-Nrf2ARE signaling system.

\begin{tabular}{ccccc}
\hline $\begin{array}{c}\text { Compound } \\
\text { Number }\end{array}$ & Compound Name & $\begin{array}{c}\text { Common Dietary } \\
\text { Sources }\end{array}$ & Scientific Name & References \\
\hline $\mathbf{1}$ & Zerumbone & Ginger & $\begin{array}{c}\text { Zingiber zerumbet } \\
\text { Smith. }\end{array}$ & {$[39]$} \\
\hline
\end{tabular}


Table 2. Cont.

\begin{tabular}{|c|c|c|c|c|}
\hline $\begin{array}{l}\text { Compound } \\
\text { Number }\end{array}$ & Compound Name & $\begin{array}{c}\text { Common Dietary } \\
\text { Sources }\end{array}$ & Scientific Name & References \\
\hline 2 & Khayandirobilide A & $\begin{array}{l}\text { Stem barks, fruits, } \\
\text { and leaves of } \\
\text { African mahogany }\end{array}$ & Khaya senegalensis & {$[40]$} \\
\hline \multirow{2}{*}{3} & \multirow{2}{*}{ Brusatol } & $\begin{array}{l}\text { Dried ripe fruits of } \\
\text { Brucea javanica }\end{array}$ & Brucea javanica & [41] \\
\hline & & $\begin{array}{c}\text { Seeds of } \\
\text { Brucea sumatrana }\end{array}$ & Brucea sumatrana & [42] \\
\hline 4 & Withaferin A & Ashwagandha & Withania somnifera & [43] \\
\hline 5 & Betulin & $\begin{array}{l}\text { Silver Birch } \\
\text { tree bark }\end{array}$ & Betula pendula & [44] \\
\hline 6 & Ganodermanondiol & Lingzhi mushrooms & Ganoderma lucidum & [45] \\
\hline \multirow{3}{*}{7} & \multirow{3}{*}{ Oleanolic acid } & Olive leaves & Olea europaea & \multirow{3}{*}[46]{} \\
\hline & & Jujube & $\begin{array}{l}\text { Ziziphus jujube } \\
\text { Mill. }\end{array}$ & \\
\hline & & Ginseng & Panex sp. & \\
\hline 8 & Ursolic acid & Apple peels & Malus domestica & [47] \\
\hline \multirow{3}{*}{9} & \multirow{3}{*}{ Dioscin } & \multirow{3}{*}{$\begin{array}{c}\text { Leaves and } \\
\text { rhizomes of plants } \\
\text { from Dioscoreaceae } \\
\text { family }\end{array}$} & Dioscorea opposita & \multirow{3}{*}{ [48] } \\
\hline & & & Dioscorea alata & \\
\hline & & & Dioscorea japonica & \\
\hline \multirow{6}{*}{10} & \multirow{6}{*}{ Corosolic acid } & Kosam & $\begin{array}{l}\text { Schisandra } \\
\text { chinensis }\end{array}$ & \multirow{6}{*}{ [49] } \\
\hline & & Loquat & Eriobotrya japonica & \\
\hline & & Banaba & $\begin{array}{l}\text { Lagerstroemia } \\
\text { speciosa L. }\end{array}$ & \\
\hline & & Java tea & $\begin{array}{l}\text { Orthosiphon } \\
\text { stamineus }\end{array}$ & \\
\hline & & Java tea & $\begin{array}{l}\text { Orthosiphon } \\
\text { aristatus }\end{array}$ & \\
\hline & & Korean weigela & Weigela subsessilis & \\
\hline \multirow{3}{*}{11} & \multirow{3}{*}{ Lycopene } & Papaya & Carica papaya & \multirow{3}{*}{ [50] } \\
\hline & & Tomato & $\begin{array}{c}\text { Solanum } \\
\text { lycopersicum }\end{array}$ & \\
\hline & & Watermelon & Citrullus lanatus & \\
\hline \multirow[b]{2}{*}{12} & \multirow[b]{2}{*}{ Astaxanthin } & Salmon & Salmo salar & \multirow[b]{2}{*}[51]{} \\
\hline & & Trout & $\begin{array}{c}\text { Oncorhynchus } \\
\text { mykiss }\end{array}$ & \\
\hline \multirow[t]{2}{*}{13} & \multirow{2}{*}{ Fucoxanthin } & Microalgae & $\begin{array}{l}\text { Phaeodactylum } \\
\text { tricornutum }\end{array}$ & \multirow[t]{2}{*}[52]{} \\
\hline & & seaweeds & Undaria pinnatifida & \\
\hline
\end{tabular}




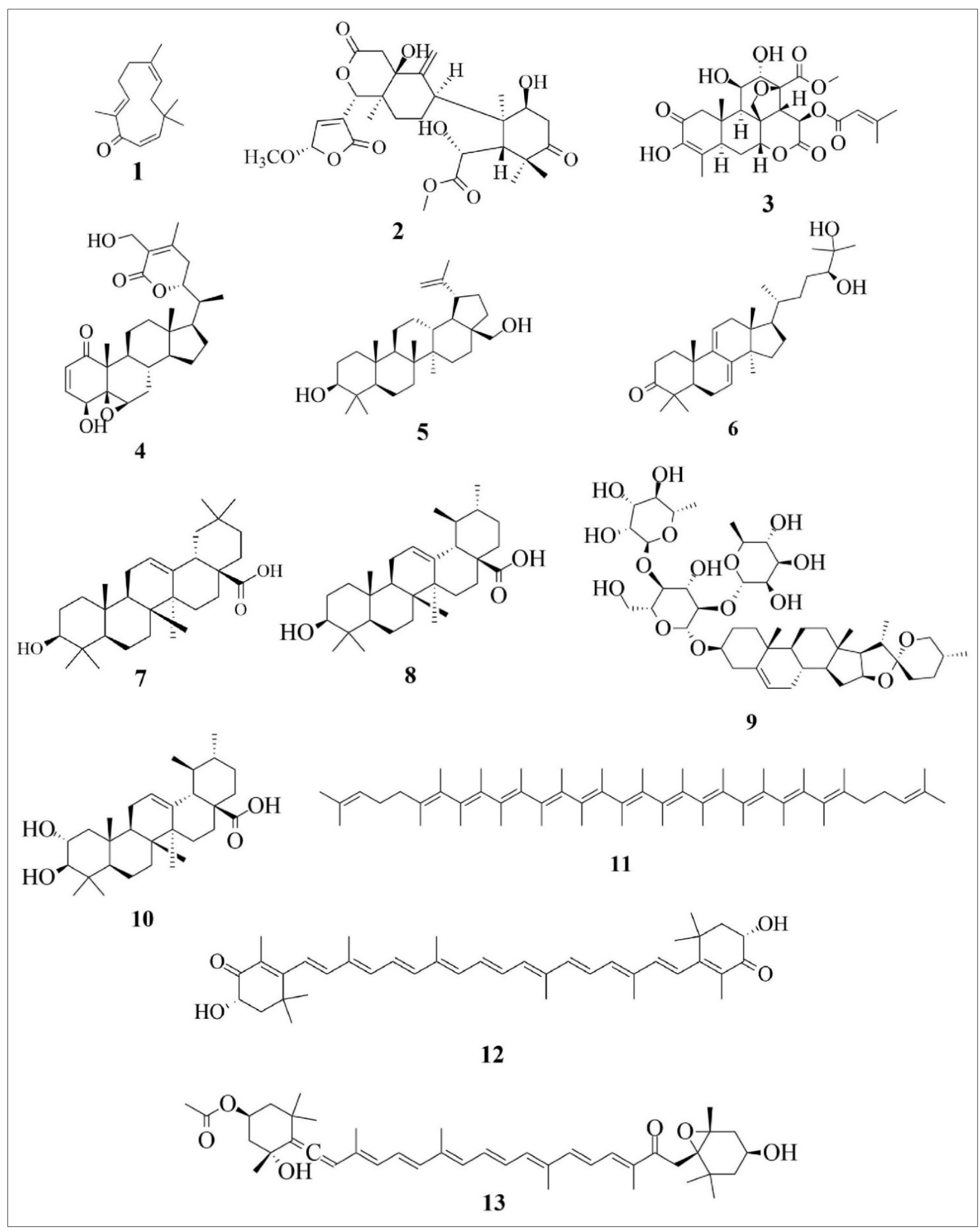

Figure 2. Chemical structures of the dietary terpenoids that can modulate the Keap1-Nrf2-ARE signaling system. (1) zerumbone, (2) khayandirobilide A, (3) brusatol, (4) withaferin A, (5) betulin, (6) ganodermanondiol, (7) oleanolic acid, (8) ursolic acid, (9) dioscin, (10) corosolic acid, (11) lycopene, (12) astaxanthin, and (13) fucoxanthin. 


\section{Keap1-Nrf2-ARE Signaling System}

Nrf2 is a member of the Cap ' $n$ ' collar transcription factor family that contains a distinct $\mathrm{CNC}$ domain that is connected to the $\mathrm{N}$-terminal side of a greatly protected leucine zipper (bZIP) motif. Nrf2 performs its function through pairing with other bZip proteins, such as small MAF proteins, facilitating dimerization, DNA binding, and nuclear export-import. Nrf2 modulates antioxidant and detoxification gene expression and has been established as a tumor suppressor [53]. In different experiments, Nrf2-knockout mice demonstrated enhanced carcinogen susceptibility and increased metastasis of the lung, which was guided by elevated ROS levels $[54,55]$. Keap1, the major Nrf2 repressor, is an adaptor subunit of Cullin3-based E3 ubiquitin ligase that works as a sensor element for oxidative stresses [56]. The Keap1-Nrf2-ARE signaling system is critical for maintaining a healthy balance between the ROS and the redox state of cells [57]. Nrf2 binds to the endogenous AREs to form the Nrf2-ARE complex, which needs to be activated when needed. Activity of this complex is restricted during the period in which it binds with Keap1 [58]. Under basal conditions, the Nrf2-Keap1 complex is anchored to cytosolic actin [59] and allows the Nrf2 to react with ubiquitin. Ubiquitination subsequently hydrolyzes it to its subcellular organelles and halt DNA transcription [60]. On the contrary, the ubiquitination can be prevented by breaking down the Nrf2-Keap1 complex [58-60]. This usually happens when cells undergo oxidative stress due to the presence of excessive intracellular ROS. Here, Keap1 works as a redox sensor, as it contains a sulfhydryl group in the cysteine residues that can sense oxidative stress. Due to the electrophilic nature of ROS, they tend to react with the cysteine residues of Keap1 protein, and subsequently break the Keap1-Nrf2 complex. Free Nrf2 becomes phosphorylated at Ser 40 and translocates into the nucleus from cytosol to bind with the ARE region of DNA [61]. Thus, it activates the transcription of genes encoding for antioxidant elements and accordingly triggers several downstream enzymes including HO-1, thioredoxin (TXN), thioredoxin reductase (TXNRD), superoxide dismutase (SOD), NQO1, glutathione reductase (GR), GCL, glutathione-S-transferase (GST), UDPglucuronosyltransferase (UGT), etc., [62,63]. Therefore, this overall system is known as the Keap1-Nrf2-ARE signaling system. Over 500 genes are regulated by the Nrf2-ARE complex, including phase I and II detoxification enzymes, proteasome subunits, transport proteins, growth factors and some other transcription factors [64].

The indirect activation of the Nrf2 signaling pathway involves stress-response protein kinases including PKC, mitogen activated protein kinase (MAPK) cascade, PI3K, extracellular signal regulated kinase (ERK), c-Jun N-terminal kinase (JNK), etc., [65-69]. Transcription factors like heat shock factor 1 (Hsf1), p53, p65, nuclear factor- $\mathrm{kB}$ (NF- $\mathrm{KB}$ ), peroxisome proliferator activated receptor $\gamma(\operatorname{PPAR} \gamma)$, etc., are either positively or negatively involved in the regulation of Nrf2 activity [70-74]. A new but poorly studied Nrf2 activation mechanism has been established of late, the non-canonical pathway, where proteins like p62, p21, dipeptidyl peptidase III (DPP3), wilms tumor gene on X chromosome (WTX), etc., abrogate the Nrf2-Keap1 complex by directly interacting with Keap1, which in turn disrupts Nrf2 ubiquitination and thereby facilitates Nrf2 nuclear translocation and its subsequent activation [75]. Figure 3 represents how Nrf2 works intracellularly under both basal and stress conditions, and Figure 4 summarizes the factors that are involved in Nrf2 regulation. 
A. Basal Condition

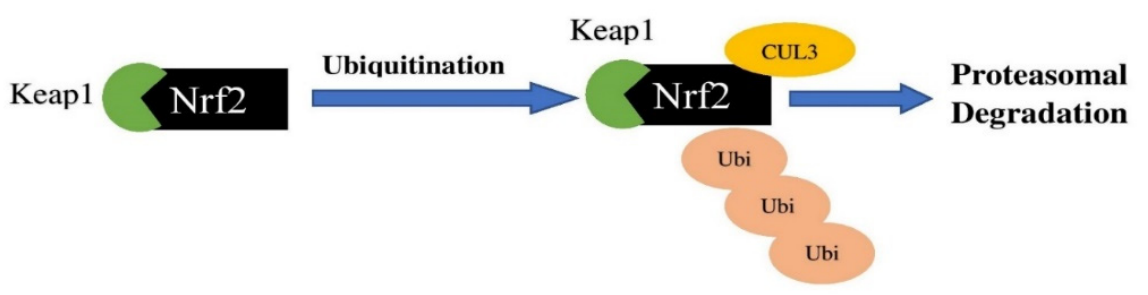

B. Stress Condition

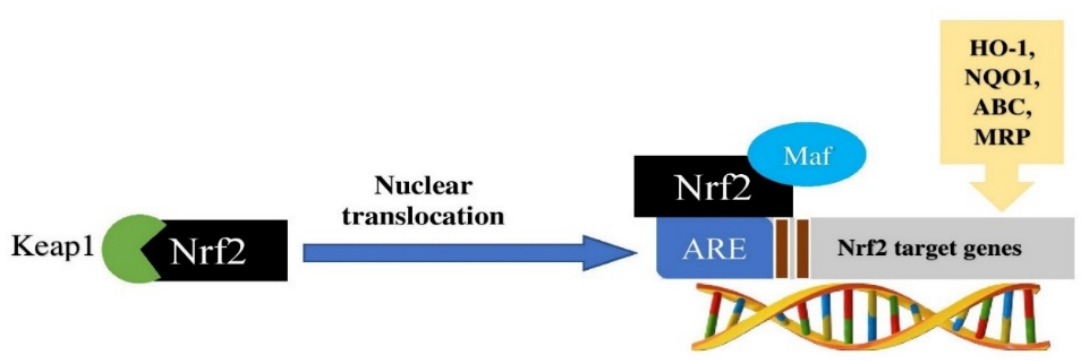

Figure 3. The basic Keap1-Nrf2-ARE signaling system. (A) Hydrolyzation of Nrf2 under basal conditions by ubiquitination. (B) Breakdown of Keap1-Nrf2 complex under stress conditions and nuclear translocation of Nrf2.

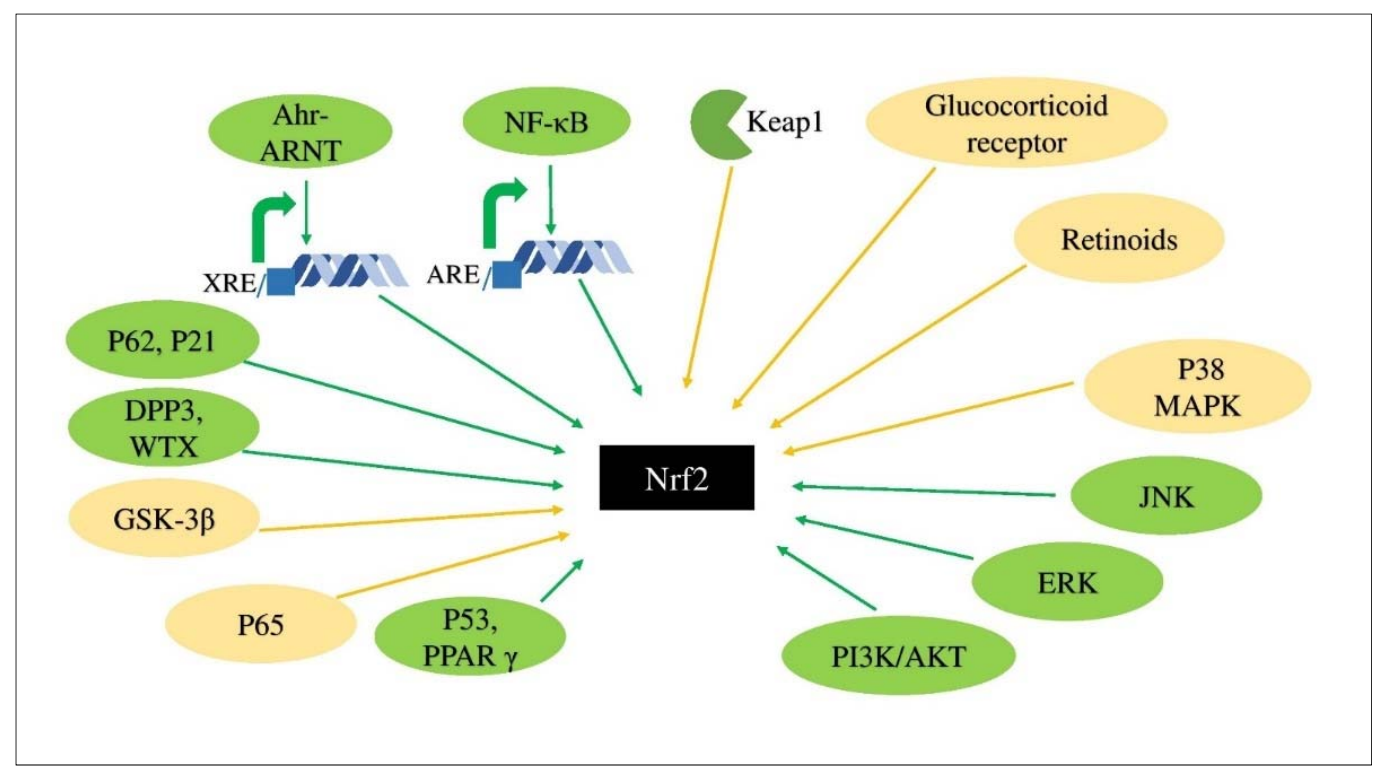

Figure 4. Various factors participate in Nrf2 regulation. The yellow color suggests the suppression of Nrf2 expression and the green color suggests the elevation on Nrf2 expression. The diagram was adapted and modified from Basak, P. et al., 2017 [56].

\section{Role of Dietary Terpenoids in Modulating the Keap1-Nrf2-ARE Signaling System}

\subsection{Zerumbone (ZB)}

Zerumbone (1) is a sesquiterpene that naturally occurs in the herbal plant Zingiber zerumbet Smith and its rhizome ginger. ZB scavenges different cell lines from oxidation-induced injury via its antioxidant effects $[39,76]$. One of the antioxidant roles of $Z B$ arises mainly because of the presence of an $\alpha, \beta$-unsaturated carbonyl moiety in its skeleton, serving as an electrophile [39]. 
The $\alpha, \beta$-unsaturated carbonyl group in ZB forms a covalent bond with Keap1 to activate Nrf2 [77].

ZB suppressed the migration and invasion of colorectal cancer cells in vitro by inhibiting the focal adhesion kinase (FAK)/PI3K/NF-KB signaling pathway [78]. The FAKdependent signaling pathway helps tumor progression and consequent metastasis by causing cell migration, invasion, transition, and angiogenesis $[79,80]$. In addition, the antioxidative action of $\mathrm{Nrf} 2$ and its associated detoxifying enzymes is dependent on the inhibition of the NF- $\mathrm{KB}$ signaling pathway [81]. Therefore, the capacity of ZB to combat colorectal cancer might be indirectly related to the Nrf2 signaling pathway. The suppression of NF- $\mathrm{kB}$ activity by ZB was also observed in AGS gastric cancer cells; the vascular endothelial growth factor (VEGF) expression was also downregulated [82]. A recent review gathered the accumulated evidence supporting the role of $\mathrm{ZB}$ in the amelioration of cancer in various cancer cells [83]. Here, ZB showed significant cytotoxicity against Raji (EpsteinBarr virus), promyelocytic leukemia HL-60, CCL-240, murine lymphoid neoplasm P-388D1, CCL-46, liver cancer HepG2, breast cancer MCF-7, MDA-MB231, lung cancer A549, ovarian cancer Caov-3, cervix cancer HeLa, etc., cells. In HEK 293 cells, ZB exhibited cytoprotective action by enhancing the protein levels of Nrf2 and ARE-dependent transcriptional activity, which in turn increased the expression of NQO1 and HO-1 [84]. In THP-1 cell-derived macrophages, ZB mediated anti-inflammatory action by abrogating the induction of NF- $\mathrm{KB}$ p65 and toll-like receptor 2/4 (TLR-2/4) [85].

ZB prevented ultraviolet (UV)-induced photoaging and skin carcinogenesis by increasing the nuclear translocation of $\mathrm{Nrf2}$ and enhancing the ARE luciferase activity, whereby the Nrf2/ARE signaling pathway was accompanied by HO- 1 and $\gamma$ glutamate cysteine ligase catalytic subunit ( $\gamma$-GCLC) gene induction [86]. Protection of skin keratinocytes and fibroblasts requires the action of Nrf2 signaling against UVA-induced oxidative insult [87,88]. Nrf2 safeguards cells from oxidative injury by means of its target genes, such as HO- 1 , and suppresses cellular malignant transformation [89]. ZB-induced Nrf2 transcriptional activation was mediated by upregulated expression of p38 MAPK, PI3K/protein kinase B (AKT), and PKC signaling pathways [86]. According to another study, ZB upregulated the expressions of antioxidant enzymes HO- 1 and $\gamma$-GCLC via increased nuclear accumulation of Nrf2, and decreased cytosolic Keap1 content by means of the ERK, JNK, PI3K/AKT, PKC, and AMP-activated protein kinase (AMPK) signaling pathways [90]. The chemical adduction, oxidation or glutathionylation of single or several important cysteine residues in Keap1 disturbs the association between Keap1 and Nrf2, making it possible for Nrf2 nuclear translocation to activate cytoprotective genes $[86,91]$. In response to oxidant injuries, Nrf2 binds to cis-acting AREs in the promoter site of phase II antioxidant encoding genes, leading to the expression of their respective proteins [90]. Acute lung injury was ameliorated by ZB as well, whereby it abolished lipopolysaccharide (LPS)-induced lipid peroxidation and promoted the activation of antioxidant defense system [92]. Here, nuclear expression of Nrf2 was markedly enhanced, and therefore the expressions of HO-1, catalase (CAT), SOD and Gpx were upregulated. Mechanistically, inhibition of two specific signaling pathways namely TLR4/NF- $\mathrm{KB}$ /cyclooxygenase-2 (COX-2) and p38 MAPK/JNK-IкB/NF- $\mathrm{kB}$ by ZR were implicated in the amelioration of acute lung injury $[93,94]$. Moreover, ZB markedly enhanced the expressions of antioxidant enzymes SOD, Gpx, and GSH and suppressed the production of malondialdehyde (MDA). Finally, it induced an anti-skin carcinogenic effect in female mice, wherein Nrf2 and its downstream target gene HO-1 were upregulated after topical administration of $\mathrm{ZB}$ on the dorsal skin of mice [95]. Figure 5 presents the mechanism of Nrf2 activation by ZB.

\subsection{Khayandirobilide A (KLA)}

Khayandirobilide A (2) is an andirobin-type limonoid compound, characterized by a modified furan ring present in its structure. It was first isolated and purified from the stem barks of K. senegalensis [40]. 
KLA exhibited anti-inflammatory activity by abrogating the production of LPSinduced nitric oxide in BV-2 microglial cells. Moreover, it downregulated interleukin (IL)-6, inducible nitric oxide synthase (iNOS), and COX-2 expression [40]. KLA also inhibited the activation of NF-KB and activator protein-1 (AP-1), and upregulated HO-1 expression by Keap1 autophagic degradation and Nrf2 nuclear translocation. Several reports suggest overexpression of NF- $\mathrm{KB}$ activity is associated with the progression of breast and colon carcinoma [96-98]. It is also evident that AP-1 activation is required for tumor promotion and progression [99]. Oxidative stress mediated several inflammatory pathway proteins, i.e., NF- $\mathrm{KB}, \mathrm{AP}-1$, iNOS, COX-2, IL-6, etc., leading to the transformation of normal cells into tumor cells [100], suggesting the role of anti-inflammatory agents like KLA in potential chemoprevention. Figure 6 presents the mechanism of Nrf2-ARE activation by KLA.

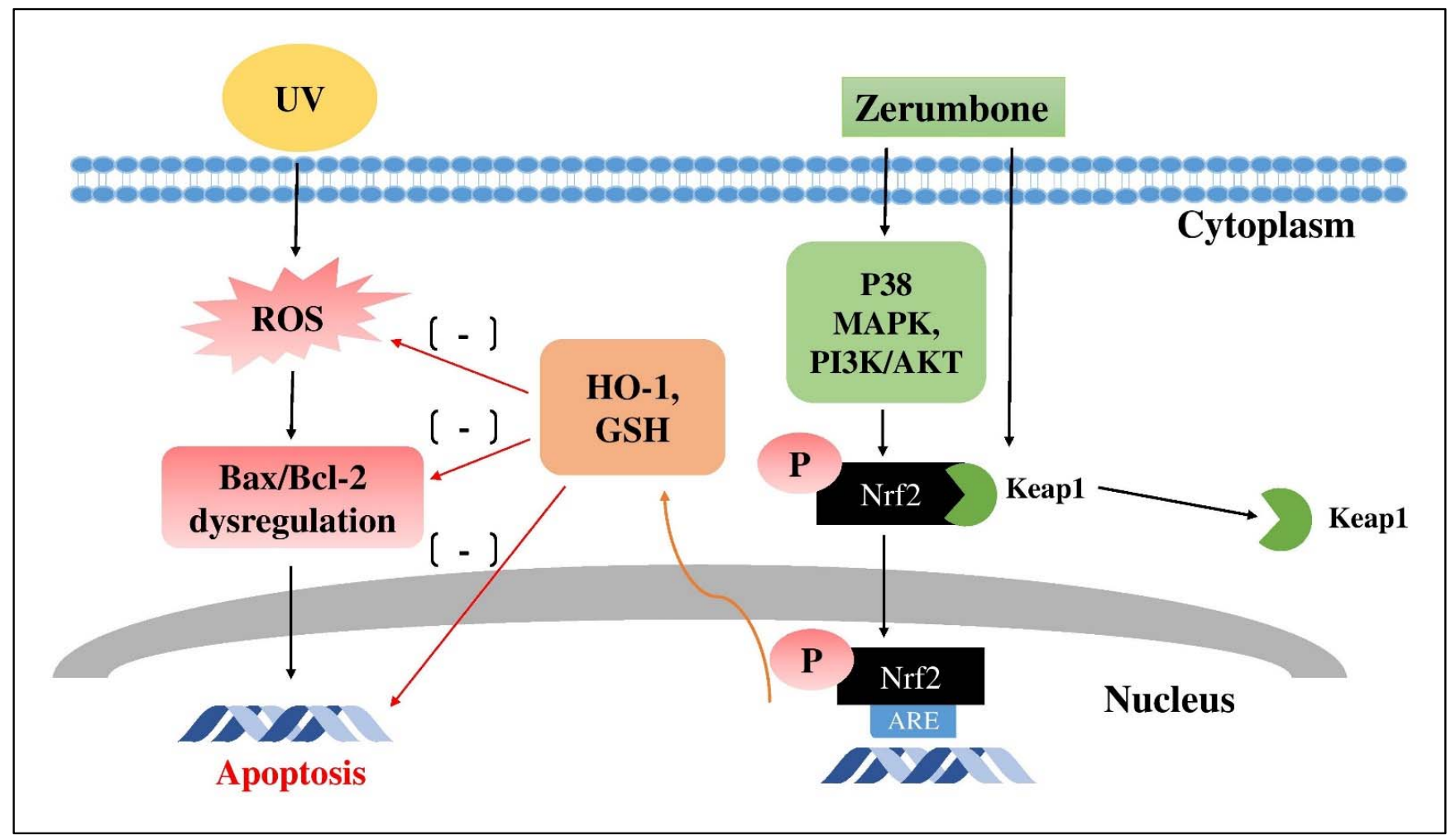

Figure 5. Mechanism of Nrf2 activation by ZB. The diagram was adapted and modified from Yang, H.-L. et al., 2018 [86].

\subsection{Brusatol (BT)}

Brusatol (3), a quassinoid present in Brucea sumatrana and B. javanica, exhibits a potent tumor suppressing effect [42]. It suppresses $\mathrm{Nrf} 2$ expression by upregulating protein ubiquitination, disrupting intracellular redox balance.

In many cancer types, it has been observed that high constitutive expression of Nrf2 builds up a conducive environment for the survival and proliferation of cancer cells [101]. Therefore, specific Nrf2 inhibitors are a must in such circumstances in order to tackle these cancer cells. BT sensitized a broad spectrum of cancer cells, including A549 xenografts to cisplatin, where it selectively decreased the protein levels of Nrf2 via increased ubiquitination and degradation of Nrf2 [101]. Consequently, the expressions of Nrf2-downstream genes were reduced, and the Nrf2-dependent cellular response was suppressed. This co-treatment of BT and cisplatin reduced cell proliferation, inhibited tumor growth, and induced apoptosis more substantially than cisplatin treatment alone. Combinatorial therapy of BT with chemotherapeutic drugs has demonstrated better outcomes than using BT alone. It synergistically enhanced the antitumor activity of trastuzumab against human epidermal 
growth factor receptor 2 (HER2)-positive SKOV3 and BT-474 cells, which was modulated by the inhibition of the Nrf2/HO-1 and HER2-AKT/ERK1/2 signaling pathways [102]. Combination of BT and metformin overcame progestin resistance by downregulating Nrf2/aldo-keto reductase family 1 member C1 (AKR1C1) in endometrial cancer [103]. BT also improved sensitivity to taxol as a result of Nrf2 suppression and ROS level upregulation in MCF-7 and MDA-MB-231 breast cancer cells [104]. BT and sorafenib in combination ameliorated hepatitis $C$ virus-associated hepatocellular carcinoma and increased the efficacy of the anticancer drug [105]. This combinatorial therapy inhibited Nrf2 expression and enhanced NF-kB, tumor necrosis factor (TNF), and MAPK pathways in order to exert its effect. BT treatment in combination with UVA inhibited A375 melanoma cell growth via G1 phase cell cycle arrest and apoptosis induction which involved partial suppression of Nrf2 and its target gene, HO-1, through the PI3K/AKT signaling pathway [106]. A quite similar mechanism was found for the amelioration of nasopharyngeal carcinoma [107]. Here, BT mediated the mitochondrial apoptosis and cell cycle arrest that followed the suppression of the AKT/mammalian target of rapamycin (mTOR) signaling. BT and cytarabine in combination exerted an anti-tumor effect in acute myeloid leukemia by inhibiting Nrf2, which in turn downregulated the expression of glycolysis-related proteins and reduced glucose uptake and lactate production [108]. In Hepa-1c1c7 hepatoma cells, BT imparted improved chemoresistance by inhibiting Keap1-independent Nrf2 signaling [109]. Again based on Nrf2 inhibition, BT remarkably suppressed the viability of A549 cells and promoted apoptotic processes [110]. The Nrf2 inhibitory action of BT is correlated with its capacity to suppress tumorigenicity and tumor cell migration and invasion [111]. For instance, in PATU-8988 and PANC-1 pancreatic cancer cells, it mediated apoptosis by inactivating NF- $\mathrm{kB}$ / signal transducer and activator of transcription 3 (STAT3) and activating JNK/p38 MAPK signaling [112]. As a potential inhibitor of Nrf2 and STAT3, BT actively suppressed tumor formation and progression in head and neck squamous cell carcinoma, as well [113].

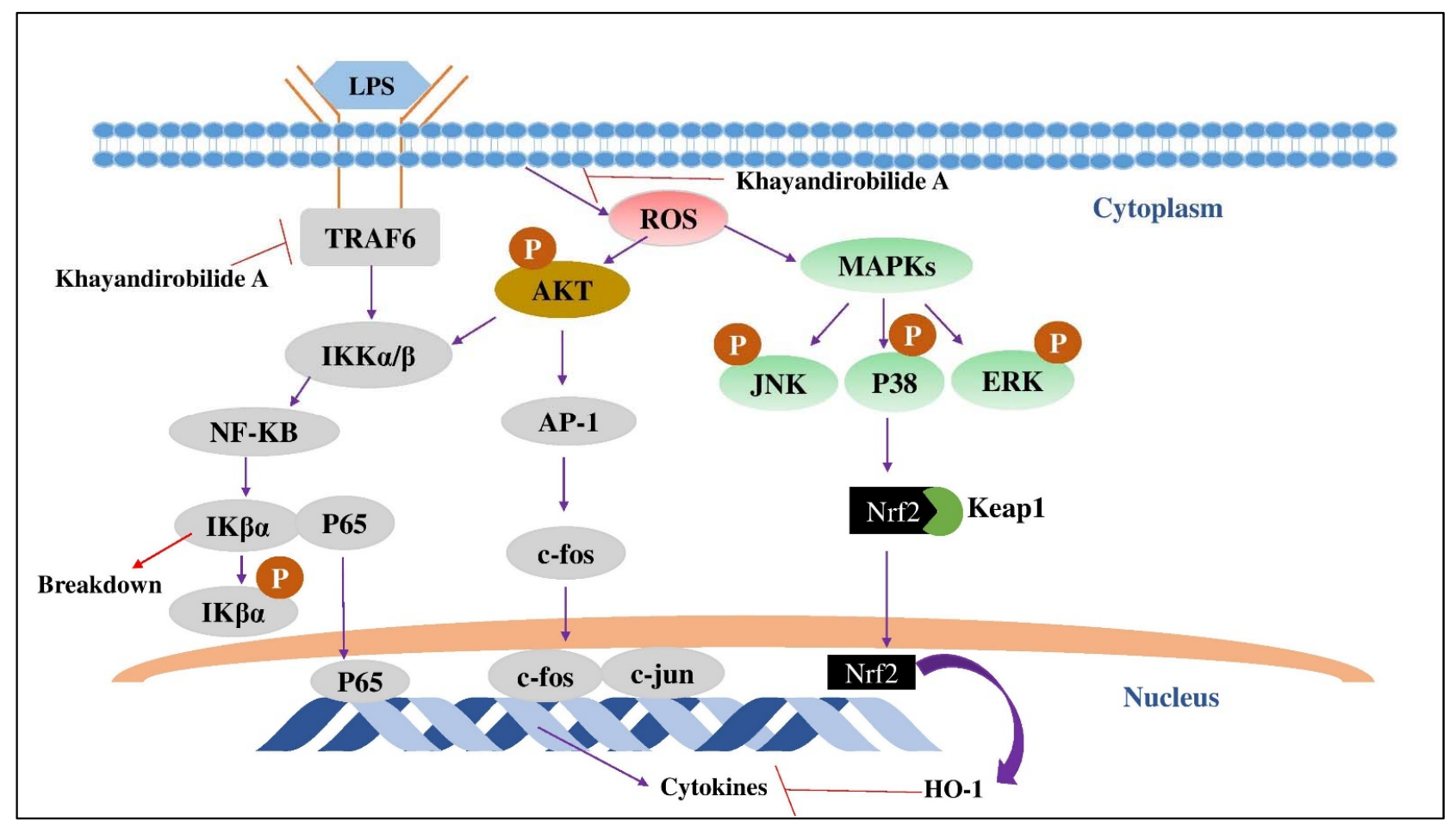

Figure 6. Mechanism of Nrf2-ARE activation by KLA. The diagram was adapted and modified from Zhou, M.-M. et al., 2018 [40].

Disruption of PI3K/AKT/NF- KB signaling by BT caused inhibition of epithelial mesenchymal transition (EMT) in order to exert its potent anti-gastric cancer effect [114]. 
Involvement of the EMT inhibition by BT was recently reported in another study, wherein, in combination with Paclitaxel, it abolished triple-negative breast cancer [115]. It ameliorated laryngeal carcinoma by disrupting the metastasis and EMT of invasive cells, mediated by downregulation of Janus kinase 2 (JAK2)/STAT3 signaling [116]. However, some chemotherapeutic roles of BT were accompanied by upregulation of STAT3 expression. For example, suppression of metastasis by BT was recently reported in hepatocellular carcinoma, whereby EMT was abrogated by an enhanced level of STAT3 expression [117]. Nano-molar concentrations of BT, as an Nrf2 inhibitor, caused DNA damage and reactivated NR4A3 gene expression to heal acute myeloid leukemia [118]. Several other reports have demonstrated the effective Nrf2 inhibitory role of BT in the management of pancreatic and colorectal cancers $[119,120]$. A recent review also reported BT to be a specific Nrf2 inhibitor and described its anticancer role in the amelioration of various cancers [121]. However, a recent report demonstrated the role of enhanced Nrf2/HO-1 signaling in mediating the tumor suppressing effect of BT in U-251 glioma cells [122]. Here, the PI3K/AKT/mTOR signaling was inhibited during the exertion of the anti-neurotoxic effect. As far as the dual role of Nrf2 in cancer chemoprevention is concerned, targeted inhibition of Nrf2 signaling has attracted a great deal of focus in the last decade for certain cancer cell types [123], suggesting the promising role of BT in cancer prevention.

\subsection{Withaferin $A$ (WFA)}

Withaferin A (4) was isolated from traditional Indian medicinal herb Withania somnifera roots and has been studied extensively for its anti-inflammatory, and cardioprotective effects [124]. It has been found to be effective in ameliorating a wide variety of cancers including breast, cervical, ovarian, prostate, oral, glioblastoma, and pancreatic cancer $[125,126]$. The chemical structure of WFA contains $\alpha, \beta$-unsaturated carbonyl moieties [127]. Therefore, it might work as a Michael acceptor and a thiol modifier; in particular, WFA might have an interesting role in the modification of Keap1-cysteine thiol residues. This modification might help Nrf2 to disassociate from Keap1, thus allowing it to be activated.

The Nrf2-induced oxidative stress response pathway was implicated in the anticancer action of WFA [128]. According to this model, under oxidative stress, WFA bound with Keap1, freeing Nrf2 to be translocated into the nucleus. Thus, the enhanced Nrf2 bound with AREs in order to upregulate its downstream antioxidant enzymes. Robust induction of Nrf2 by WFA was recently reported in the treatment of human breast cancer cells [129]. This study concluded that Nrf2 helped in the mediation of apoptosis and autophagy in several breast cancer cells. Induction by WFA of Nrf2 and its associated detoxifying enzymes was also reported to produce an effective cytoprotective response in both in vitro and in vivo models [130]. This withaferin A-mediated Nrf2 and ARE induction followed a unique Keap1-independent phosphatase and tensin homolog (PTEN)/PI3K/AKT signaling pathway. In this case, the Nrf2-dependent cytoprotective genes were significantly induced even under Keap1-deprived conditions. WFA upregulated the mRNA expression of Nrf2 and its downstream antioxidant genes HO-1, glutathione-disulfide reductase (GSR), and NQO1 in Ca9-22 oral cancer cells [131]. In addition, it facilitated mild phosphorylation of the MAPK family proteins including ERK1/2, JNK, and p38. The same study reported a migration inhibitory role of WFA against oral cancer, where it abolished matrix metalloproteinase (MMP)-2 and MMP-9 activities. In J82 bladder cancer cells, WFA responded remarkably to oxidative stress by upregulating the expression of Nrf2 and its antioxidant enzymes CAT, SOD1, TXN, GSR, NQO1, and HO-1 [132]. Moreover, WFA mediated DNA strand breaks and oxidative DNA damage to the bladder cancer cells. Withania somnifera containing WFA demonstrated antioxidant and anti-inflammatory activity in BV-2 microglial cells, wherein upregulated Nrf2/HO-1 and downregulated NF-kB expression played the key role [133]. The apoptosis-inducing role of WFA has also been reported, in which ERK, JNK, and p38 MAPK signaling pathways are involved, resulting in the phosphorylation of Nrf2 and enhancement of HO-1 levels [134]. 
WFA suppressed necrotic hepatocyte injury by enhancing Nrf2, GCLC and NQO1, and abrogating IL-6, TNF- $\alpha$ and IL-1 $\beta$ expression [135]. In the same study, mitochondrial Bax translocation, JNK expression and nitrotyrosine generation were reduced in WFAtreated mice. A review on the anticancer action of WFA reported that WFA upregulated Nrf2 protein expression, thereby enhancing the expressions of HO-1, SOD, CAT, Gpx and NQO1 [127]. The accumulated evidence supporting the chronic inflammation ameliorating role of WFA was gathered in a recent review [136]. Here, reduced NF- $\kappa$ B and increased Nrf2 expression were implicated in the anti-inflammatory role of WFA. Additionally, signaling pathways like AKT/mTOR, MAPK, and JAK/STAT were involved in exerting this effect. In a recent study, inhibition of NF- $\mathrm{KB}$ expression was implicated in the anti-hepatocellular carcinoma effect mediated by WFA [137]. The anti-angiogenic pathway of WFA against lung cancer involved the inhibition of transforming growth factor $\beta 1$ (TGF- $\beta 1$ ), TNF- $\alpha$, and nuclear translocation and phosphorylation of NF- $\mathrm{kB}$ [138]. WFA also exerted antiangiogenic activity in endothelial cells by inhibiting the activation of NF- $\mathrm{B}$ [124]. Suppression of inflammatory cytokines like IL-6, TNF- $\alpha$ and NF-kB/STAT1/STAT3 signaling was implicated in the anti-colorectal cancer effect of WFA [139].

\subsection{Betulin (BE)}

Betulin (5) is a triterpene, usually found in birch tree Betulaceae sp. bark. It possesses anti-inflammatory, antibacterial and antiviral properties [44].

A review article presented the accumulated evidence of the anticancer and chemopreventive role of BE in various cancer cells, including myeloid leukemia, glioblastoma, neuroblastoma, thyroid, ovarian, breast, skin, colorectal, hepatic, prostate, oral, gastric, pancreatic, and lung carcinoma [140]. This review reported that the anticancer role of BE was mechanized either by extrinsic (TNF, Fas, etc.) or intrinsic (DNA damage, nuclear fragmentation, etc.) apoptotic factors. Evidence was found for BE's suppressive role on various cancer cells via an intrinsic apoptotic mechanism [141]. Induction of apoptosis was also implicated in the anticancer action of BE in multidrug-resistant renal carcinoma [142]. BE, extracted form Betula platyphylla demonstrated promising cytotoxicity against A549, H1264, and Calu-6 lung adenocarcinoma cells [143]. In addition, it ameliorated the side effects of chemotherapy in the same study, i.e., gastric and renal cell damage. A brief review described BE to be a direct acting agent on mitochondria [144]. Agents that act on mitochondria directly in order to exert chemotherapeutic action receive special consideration in the field of cancer studies, because they can cause cell death under conditions in which conventional chemotherapeutic agents might fail. BE exhibited anti-inflammatory activity through the dose-dependent induction of Nrf2 and its detoxifying enzymes NQO1, HO-1, GCLC and glutamate cysteine ligase modifier subunit (GCLM) [145]. This Nrf2-dependent anti-inflammatory signaling of BE followed the AMPK/AKT/glycogen synthase kinase $3 \beta$ (GSK $3 \beta$ ) signaling pathway. Nrf2 becomes phosphorylated with serine and threonine residues through $\mathrm{AKT}, \mathrm{AMPK}$, and PI3K in order to promote the discharge of Nrf2 from Keap1 and its consequent nuclear translocation for the initiation of antioxidant action to protect the cells against cancerous invasion [146]. In addition, inflammatory mediators, e.g., iNOS, COX-2, that are involved in the carcinogenic process were significantly abolished by BE [145]. Some other pro-inflammatory cytokines and chemokines that are responsible for oncogenesis, like IL-1, TNF- $\alpha$, etc., were reportedly inhibited by BE via disruption of NF- $\kappa$ B and MAPK signaling [147].

BE ameliorated 7,12-dimethylbenz(a)anthracene (DMBA)-induced mammary cancer in rats by upregulating the Nrf2 expression [148]. Downstream antioxidant enzymes like HO-1, Gpx, SOD and CAT were markedly enhanced after BE treatment. This chemopreventive effect of BE was accompanied by downregulated expression of Keap1, MAPKs, aryl hydrocarbon receptor nuclear translocator (ARNT), aryl hydrocarbon receptor (AhR), and cytochrome p450 family 1 subfamily A member 1 (CYP1A1). 


\subsection{Ganodermanondiol (GD)}

Ganodermanondiol (6) is generally found in the medicinally important mushroom Ganoderma lucidum. The main bioactive secondary metabolites of G. lucidum are triterpenoids (ganoderic acid), polysaccharides, and steroids [149].

Ethanol extract of G. lucidum, which contains GD, exhibited an effective response against $\mathrm{H}_{2} \mathrm{O}_{2}$-mediated oxidative cytotoxicity in C2C12 myoblast cells [150]. This cytoprotection was mediated by induction of Nrf2 and HO-1. An anti-colon-cancer effect was recently reported for GD [151]. It markedly hampered SW620 cell viability by mediating apoptosis. GD was found to be cytotoxic against a wide number of cancer cell lines, including HL-60 human leukemia, MDA-MB-231 breast, HepG2 liver, HeLa cervical, HCT-116 and HT-29 colon cancer cells [152-155]. It also ameliorated nasopharyngeal carcinoma [156]. In human oral epidermoid carcinoma KBv200 cells, GD reversed multidrug resistance to the anti-tumor drug doxorubicin [157]. It demonstrated potent cytoprotective effect on human liver-derived HepG2 cells via Nrf2-dependent GSH, GCL, and HO-1 antioxidant enzyme upregulation [45]. This Nrf2-centered cytoprotective action of GD was mediated by AMPK signaling. GD effectively suppressed the pronouncement of cellular melanogenesis-related proteins, i.e., transient receptor potential channel (TRP)-1, TRP-2, and microphthalmia-associated transcription factor (MITF) in B16F10 cells, which was modulated by MAPK family proteins [158]. Specifically, the ERK and JNK phosphorylation was induced but the p38 phosphorylation was abrogated by GD.

\subsection{Oleanolic Acid (OA)}

Oleanolic acid (7) is a pentacyclic triterpenoid compound naturally existing in olive leaves, jujube, ginseng, etc., either as a free acid or as an aglycone precursor [46,159]. It has been demonstrated to possess a wide array of pharmacological potentials, including hepatoprotective, anti-inflammatory, anti-viral, anti-hyperlipidemic, anti-hyperglycemic, and anti-tumor activities [159]. OA is an active suppressor of cellular inflammatory pathways and an established enhancer of phase II antioxidant enzymes [46]. It has been reported to improve malignant glioma, leukemia, liver, lung, breast, colon, bladder, gallbladder, prostate, and pancreatic cancer [160-168].

$\mathrm{OA}$, a known Nrf2 activator, reportedly upregulated the expression of Nrf2 and its target antioxidant enzymes, including NQO1, HO-1, GCLC, and GCLM, to exert cytoprotective effect in hepatocytes [169]. In A549 lung cancer cells, OA and ursolic acid activated the Nrf2/ARE signaling [170]. In addition, this combination enhanced the p62 expression in A549 cells. Conjugation of diclofenac with OA derivatives exhibited enhanced chemopreventive activity [171]. In immortalized normal THLE-2 hepatocyte cells, the OA conjugates activated Nrf2 and enhanced SOD-1 and NQO1 expression. However, in HepG2 hepatoma cells, the opposite effect was obtained, with the apoptotic pathway being induced due to increased ROS generation. In both THLE-2 and HepG2 cells, the expressions of NF- $\mathrm{kB}$ and COX-2 were suppressed. A quite similar effect was observed when OA derivatives were conjugated with indomethacin [172]. Here, the Nrf2-ARE pathway was inhibited in HepG2 cells, but not in THLE-2 hepatocytes. In another report, OA oxime derivatives provided chemopreventive response by activating Nrf2 in human hepatoma cells [173]. This study also showed that the conjugation of OA oximes with aspirin caused increased Nrf2 expression in normal THLE-2 cells, whereas the opposite effect was observed in HepG2 cells. Moreover, activation of AMPK signaling was observed in the OA-mediated anticancer effect in PC3 prostate and MCF-7 breast cancer cells [174]. OA improved tBHPmediated oxidative insult via an Nrf2-dependent increase in antioxidant enzymes GSH, CAT, and peroxiredoxins (PRX1) in which the activated signaling of JNK and ERK were involved [175]. A review reported that OA and its derivatives influenced a wide range of signaling pathways including NF- $\mathrm{KB}$, AKT, STAT3, mTOR, caspases, intercellular adhesion molecule 1 (ICAM-1), VEGF, and poly (ADP-ribose) polymerase (PARP) in different tumor cells [176]. VEGFR-2 activation was abolished by OA in HU-VECs in another study [177]. 
OA ameliorated DMBA-induced liver carcinogenesis through modulating the antioxidant level, causing apoptosis and autophagy [178]. Here, downregulation of VEGF, proliferating cell nuclear antigen (PCNA), NF- $\mathrm{KB}$, TNF- $\alpha$ and COX-2 expression and upregulation of caspase-3, Bcl-2 and Beclin-1 expression were observed. Synergistic action of grafted chitosan and OA improved liver injury by enhancing the hepatic antioxidant capacity [179]. Here, the Nrf2/Keap1 pathway played the key role in enhancing the hepatic antioxidant capacity, while hepatic inflammation was tackled by the downregulation of NF-kB signaling. OA ameliorated hepatotoxicity and provided cytoprotection against oxidative stress via Nrf2 nuclear accumulation and enhancing its target enzymes, including NQO1, GLC, GCLC and HO-1 [180]. A recent review described the role of OA in hepatoprotection, wherein activation of the Nrf2/ARE pathway was reported [181]. Here, the activated Nrf2 upregulated the expressions of GSH, NQO1 and HO-1. One study suggested that the anti-tumor potential of OA involved the generation of cellular apoptotic signals, whereby ERK-mediated Nrf2 upregulation actively suppressed ROS generation in oncogenic cells [182]. Several signaling pathways, including AMPK, ERK1/2, AKT/PI3K, ROS/apoptosis signal-regulating kinase 1 (ASK1)/p38 MAPK, and NF- $\mathrm{kB}$, were involved in modulating the anticancer activity of OA [46]. OA was demonstrated to possess promising anti-inflammatory activity, because it depleted pro-inflammatory cytokines and augmented antioxidant genes by inhibiting NF- $\mathrm{kB}$ expression and promoting Nrf2 nuclear translocation, suggesting the existence of long-discussed cross-talk between NF-KB and Nrf2 [183]. Indole derivatives OA exhibited anti-inflammatory action both in vivo and in vitro [184]. This action against inflammation was accompanied by inhibition of NO, pro-inflammatory cytokines, and chemokines, i.e., IL-1 $\beta$, IL-6, TNF- $\alpha$, etc., as well as enhancement of anti-inflammatory cytokine IL-10. Inhibition of NF- $\mathrm{kB}$, MAPKs and PI3K/AKT signaling and upregulation of Nrf2/HO-1 signaling regulated these cytokine expressions.

\subsection{Ursolic Acid (UA)}

Ursolic acid (8) is a naturally occurring pentacyclic triterpenoid acid found in apple peels, cranberries, blueberries, etc., which possesses a wide range of biological activities including antioxidant, antitumor and anti-inflammatory effects [185-187].

A low dose of UA effectively induced HO-1 expression in acute myeloid leukemia kasumi-1 cells [188]. However, the expression of HO-1 suppression increased the sensitization of Kasumi- 1 cells to UA, which in turn mediated more efficient apoptosis. An important chemopreventive mechanism of UA observed in human mammary epithelial and hepatocellular carcinoma cells involved the inhibition of COX-2 [189,190]. Another study supported the same notion that UA effectively promoted apoptosis in gastric cancer cells by suppressing the expression of pro-inflammatory mediator COX-2 [191]. In LNCaP and PC-3 prostate cancer cells, UA enhanced the expression of SET domain-containing lysine methyltransferase 7 (Setd7), which in turn upregulated Nrf2/ARE signaling [192]. As a result, the Nrf2 downstream enzymes NQO1 and glutathione S-transferase theta 2 (GSTT2) were enhanced, and oxidative insult was attenuated. However, a recent finding demonstrated the Nrf2 inhibitory role of UA in treating breast cancer [193]. In MDAMB-231 breast cancer cells, UA suppressed the expression of Nrf2, NQO1 and SOD1 and increased the expression of Keap1. The anti-migration and anti-invasive effects of UA in MDA-MB-231 human breast cancer cells were triggered by the downregulation of JNK, AKT, and NF- $\mathrm{KB}$ expressions [194]. UA and cisplatin combination sensitized HepG2/DDP cells to cisplatin by following an Nrf2 inhibitory mechanism, as well [195]. This combinatorial therapy worked against HepG2/DDP cells by inducing ROS generation, cell cycle arrest, and apoptosis. Moreover, UA induced apoptosis in SNG-II and HEC108 endometrial adenocarcinoma cells by inhibiting AKT/PI3K and MAPK signaling [61]. Apoptosis was also induced by UA in HCT116 and HT29 colorectal cancer cells via inhibition of JAK2/STAT3 phosphorylation [196]. UA nanoparticles ameliorated cervical cancer by 
enhancing the expressions of p53 and caspases and abrogating the anti-apoptosis-related signals [197].

It improved $\mathrm{CCl}_{4}$-induced fibrosis by modulating the Nrf2/ARE antioxidant signaling by elevating the expression of HO-1, NQO1, GST and downregulating the levels of inflammatory cytokines like TNF- $\alpha$, prostaglandin, and iNOS [198]. One study correlated the link between upregulated phase II antioxidant enzymes and downregulated inflammatory cytokines expression with chemoprevention in an in vivo rat model [199]. Again, some reviews have summarized the essential role of activated Nrf2/ARE antioxidative signaling and anti-inflammatory action in the chemopreventive role of UA [200,201]. UA helped to actively prevent skin carcinogenesis by upregulating the expression of Nrf2-dependent antioxidant enzymes such as HO-1, NQO1 and UDP-glucuronosyltransferase 1A1 [202]. A quite similar effect was obtained for UA against skin cancer, implicating the epigenetic activation of Nrf2 [203]. It demonstrated a cytoprotective effect in lung cells by upregulating the expression of Nrf2 and its target genes NQO1 and GST [204]. Non-melanoma skin cancer was improved by UA treatment, whereby Nrf2 and NQO1 expression was upregulated [205]. Additionally, the expressions of inflammatory cytokines IL- 8 and NF- $\mathrm{B}$ were suppressed.

\subsection{Dioscin (DC)}

Dioscin (9) is a steroidal saponin that is abundantly present in Dioscorea nipponica, D. zingiberensis, D. opposita, D. alata, and D. japonica [48]. It has previously been reported to ameliorate prostate, lung, gastric and skin carcinogenesis [206-209].

In HL-60 leukemia cells, it produced anticancer action by activating p38 MAPK and JNK signaling [210]. DC ameliorated LPS-induced inflammation in mouse mammary epithelial cells by enhancing the level of total and nuclear Nrf2 and its downstream enzyme HO-1 [211]. Mechanistically, the AMPK signaling was activated and the expression levels of IL-1 $\beta$, IL- 6, TNF- $\alpha$ and NF- $\kappa$ B were suppressed. A study suggested ROS production to be an important event in DC-mediated apoptosis in human esophageal cancer Kyse510 cells [212]. This ROS-generating anticancer mechanism implied the Nrf2 inhibitory role of DC, where the cellular antioxidant defense enzymes like PRX1 and PRDX6 were downregulated [213]. The ROS-mediated apoptotic role of DC against colon cancer was accompanied by JNK/p38 MAPK signaling activation [214]. In another report, activation of ERK1/2 signaling was implicated in the DC-regulated apoptotic activity in human hepatoma Huh7 cells [215]. The anti-metastatic role of DC was evident in A549 lung cancer cells, where it suppressed EMT by downregulating TGF- $\beta 1$ expression [216].

DC ameliorated hepatic fibrosis by facilitating the nuclear translocation of Nrf2, followed by its dissociation from Keap1 [217]. Consequently, by binding to the AREs, Nrf2 upregulated the expression of antioxidant enzymes HO-1, GST, GCLC and GCLM. DC improved doxorubicin-mediated liver damage by tackling oxidative stress and inflammation, and promoting apoptosis [218]. Here, it markedly increased silent information regulator 1 (Sirt1) and HO-1 expressions by mediating Nrf2 nuclear translocation and abrogating forkhead box protein O1 (FOXO1) and Keap1 expression. In addition, inflammation was inhibited by DC by reduced NF- $\kappa \mathrm{B}, \mathrm{TNF}-\alpha$, IL-1 $\beta$, and IL- 6 expressions. In addition to TLR4, these inflammatory mediators were also inhibited by DC during the amelioration of acute lung injury $[219,220]$. An ample body of other evidence was found supporting DC's capacity to improve liver fibrosis and acute liver injury and damage by suppressing oxidative insult and inflammation [221-226]. In these instances, DC facilitated Nrf2 nuclear translocation and enhanced the levels of HO-1, NQO1, GSH, GST, SOD1, GCL, GCLC, and Gpx. In addition, inflammatory mediators like IL-1 $\beta, \mathrm{IL}-6, \mathrm{TNF}-\alpha, \mathrm{I} \kappa \mathrm{B} \alpha, \mathrm{NF}-\kappa \mathrm{B}$, ICAM-1, high mobility group box 1 protein (HMGB1), and COX-2 were suppressed by DC. Several signaling pathways, such as farnesoid $X$ receptor (FXR)/AMPK, Sirt1/Nrf2, TGF- $\beta$ /smad, wingless-related integration site (Wnt) / $\beta$-catenin, PI3K, AKT, and MAPK, were involved in DC-mediated liver protection. DC induced autophagy at the early stage 
of DC-induced apoptosis by inhibiting the AKT/PI3K/mTOR and activating ERK1/2 and JNK signaling [227]. Figure 7 presents the mechanism of Nrf2-ARE activation by DC.

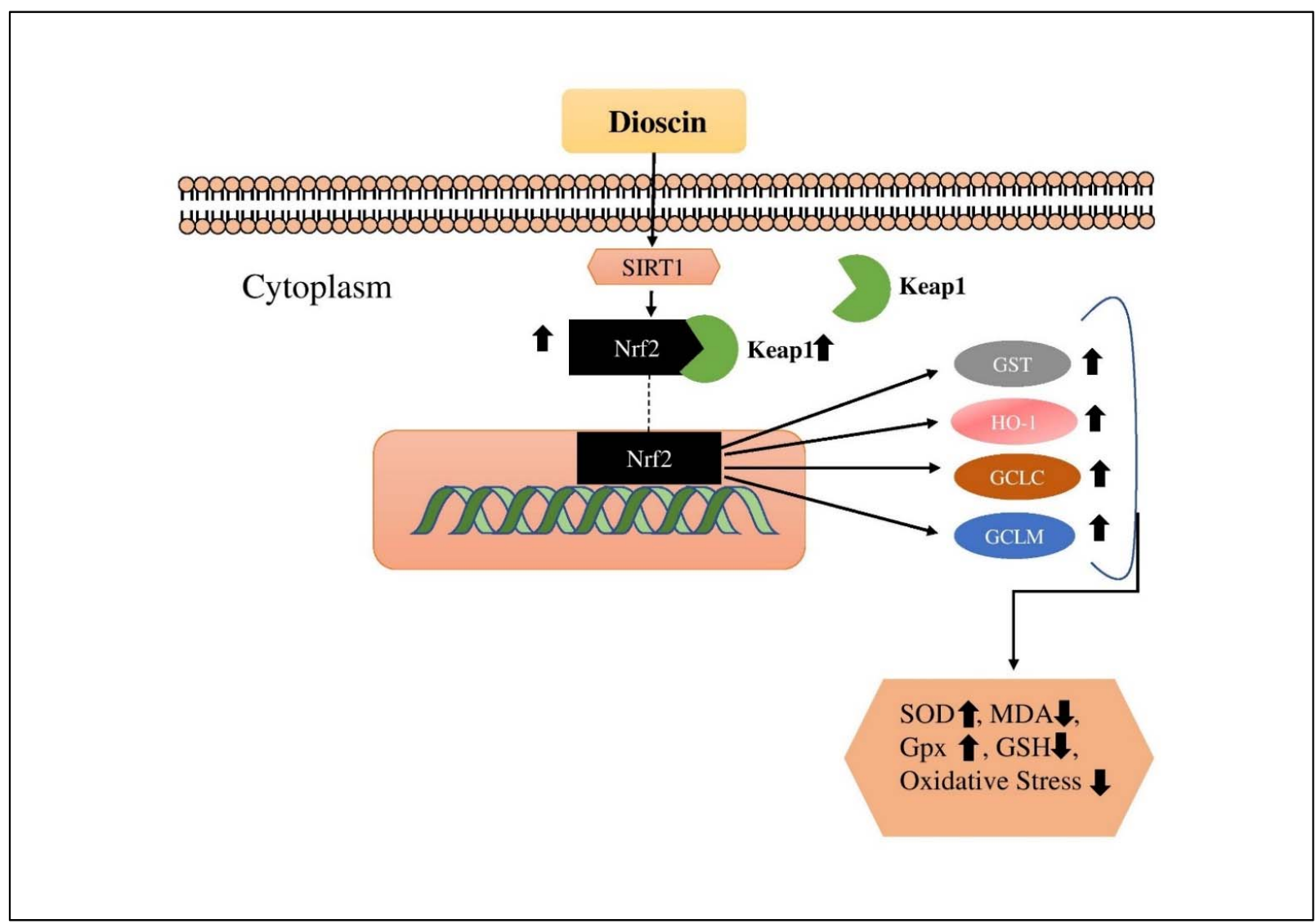

Figure 7. Mechanism of Nrf2-ARE activation by DC. The diagram was adapted and modified from Zhang, X. et al., 2015 [224].

\subsection{Corosolic acid (CA)}

Corosolic acid (10) is a triterpenoid and also known as $2 \alpha$-hydroxyursolic acid. It is usually found in Schisandra chinensis, Eriobotrya japonica, Lagerstroemia speciosa L., Orthosiphon stamineus and Weigela subsessilis [49]. It has been reported to improve several cancers, including bladder, colon, liver, breast, lung cancer, etc., [228-232].

The effect of CA on cellular transformation and upregulation of Nrf2 through epigenetic regulation in TRAMP-C1 prostate cancer cells was studied [233]. Here, CA induced mRNA and protein expression of Nrf2, and its target enzymes, such as HO-1 and NQO1. Moreover, CA abrogated the expressions of DNA methyltransferases (DNMTs) and histone deacetylases (HDACs), thereby hindering the processes of DNA hypermethylation and histone modification. This suppression of DNMTs and HDACs has extensive implications in the amelioration of prostate cancer [234,235]. CA was found to be effective in abolishing tumor initiation and lung metastasis by abrogating the COX-2 and STAT3 expression in myeloid-derived suppressor cells [236]. Moreover, CA inhibited the proliferation of U373 and T98G glioblastoma cells by preventing the activation of STAT3 and NF-KB [237]. CA ameliorated cervical cancer in a dose-dependent manner by suppressing PI3K and AKT expressions [238]. A recent review on the anticancer effect of CA reported an accumulating body of evidence supporting CA's potential effectivity against gastric, hepatocellular, colorectal, ovarian, eye, bone, and lung cancer [239]. According to the review, the anti-gastric cancer effect of $C A$ was mediated by the regulation of AMPK/mTOR, and the inhibition of NF- $\mathrm{KB}, \mathrm{HER} 2$, and EGFR/neu oncogenic signaling. In addition, CA ameliorated colorectal, ovarian and lung cancer by suppressing Wnt $/ \beta$-catenin and STAT3 signaling, respectively. 
Oxidative stress suppressing action of CA was reported in another study where CAmediated Nrf2 nuclear translocation facilitated the upregulation of HO-1, NQO1 and GCLC [240]. This ameliorative action of CA was accompanied by inhibition of JNK and activation of AMPK signaling. CA also exhibited a synergistic effect with paclitaxel, cisplatin, doxorubicin, 5-FU and Adriamycin, and markedly enhanced the sensitivity to these chemotherapeutic agents [239]. It improved acute inflammation by suppressing interleukin receptor associated kinase-2 (IRAK-2) phosphorylation, which was independent of NF-kB [241].

\subsection{Lycopene (LP)}

Lycopene (11) is an aliphatic hydrocarbon carotenoid compound. It is found in several dietary plants including papayas, tomatoes, and watermelons [50]. LP, a master regulator of oxidative stress, has previously been shown to exhibit anti-proliferative, antioxidant and anti-inflammatory properties [50,242].

Several studies using in vitro and in vivo experimental models have shown that the concentration of LP in serum and tissue can prevent the formation of human prostate cancer [243]. The amelioration of prostate cancer by LP might be both Nrf2 dependent and independent [244]. The role of Nrf2 and its antioxidant enzymes might vary in androgendependent and -independent prostate cancer cells. For instance, LP mediated a greater enhancement of GSH, GCL, GST- $\pi$, NQO1 and Nrf2 expressions in androgen-resistant DU145 cells than in androgen-dependent C4-2 cells [245]. Mechanistically, one study suggested the downregulation of AKT2 expression by LP in treating prostate cancer [246]. The suppression of NF- $\mathrm{kB}$ expression was also implicated in the management of prostate and breast cancer [247]. A recent study reported that LP enhanced the cisplatin sensitivity to cervical cancer cells by abolishing cell viability, enhancing Bax and suppressing Bcl-2 expressions [248]. Here, LP abrogated the NF-kB-induced inflammatory pathway and enhanced Nrf2 expression, recucing oxidative stress. LP downregulated the expression of MMP-7 by blocking the phosphorylation of ERK1/2, GSK-3 $\beta$, and AKT/PI3K in HT-29 colorectal cancer cells in order to exert its chemotherapeutic role [249]. In MDA-MB468 breast cancer cells, LP exhibited potential chemotherapeutic properties, whereby it provided promising ERK1/2 activation and inhibition of AKT phosphorylation and its downstream target mTOR [250]. It upregulated the Nrf2 dependent antioxidant enzymes HO-1 and GSH in endothelial cells [251]. In addition, it blocked the expression of TNF- $\alpha$ and NF- $\mathrm{kB}$ activation in the same cells. Studies on human colorectal and prostate cancers demonstrated that LP actively reduced inflammation in cancer cells by inhibiting the release of inflammatory cytokines like iNOS, COX-2, prostaglandin E2, nitric oxide, IL$1 \beta$, IL-6, and TNF- $\alpha$, thereby blocking the activation of NF-KB and JNK [252,253]. LP exhibited antioxidant and anti-inflammatory activities in retinal pigment epithelium cells by abolishing ICAM-1 expression and inhibiting NF- $\mathrm{B}$ activation [254]. In addition, it enhanced Nrf2 expression in nuclear extracts, facilitating the transactivity of the AREs and therefore increasing the intracellular GSH and GCL expression.

LP prevented ovarian cancer in laying hens by reducing the serum level of MDA and abrogating the expression of NF-kB [255]. Additionally, Nrf2 and HO-1 expressions were enhanced, whereas STAT3 expression was suppressed by LP. Hepatocarcinogenesis was prevented by LP as a consequence of diminished oxidative stress [256,257]. Here, Nrf2, HO-1, CAT, SOD and Gpx expressions were enhanced, inflammatory cytokines TNF- $\alpha$, IL-1 $\beta$ and IL-12 were reduced, and NF- $\mathrm{B}, \mathrm{COX}-2, \mathrm{ERK}$, and AKT/mTOR activations were suppressed. LP ameliorated cutaneous tumors by stimulating the Nrf2 signaling pathway and causing p62-regulated degradation of Keap1 through a unique lysosome-mediated autophagic mechanism [258]. LP also improved DMBA/12-O-tetradecanoylphorbol-13acetate (TPA)-mediated oxidative stress and skin carcinogenesis in a mouse model [259]. Here, it promoted nuclear translocation of Nrf2, enhanced the levels of CAT, HO-1, Gpx, SOD and GR, and thereby prevented ROS and MDA generation. A recent review on the mechanism of chemotherapeutic potential of LP reported that modulation of Nrf2/NF- $\mathrm{B}$ 
transcription played the key role in treating different malignancies [260]. It is known that chronic inflammation is a big driving factor in the process of tumor relapse and further carcinogenesis. Another recent review on the molecular mechanism of anticancer potentials of LP described the immunomodulatory and anti-inflammatory role of LP in preventing different cancers [261]. Chronic prostatitis/chronic pelvic pain syndrome was also ameliorated by LP, whereby it upregulated the phosphorylation of Nrf2 and enhanced the levels of CAT, Gpx, and T-SOD [262]. Additionally, it inhibited the expressions of chemokines and cytokines like monocyte chemoattractant protein 1 (MCP1), macrophage inflammatory protein-1 $\alpha$ (MIP-1 $\alpha)$, TNF- $\alpha$, IL-1 $\beta$, IL-2, and IL-6, and abrogated the MAPKs phosphorylation. LP improved aflatoxin $\mathrm{B}_{1}$ and LPS-induced liver injury in mice by abolishing oxidative stress [263,264]. Here, LP pretreatment caused an increase in Nrf2, GST and GSH expressions, and reduction of TNF- $\alpha$, IL-6 COX-2, NF- $k$ B, ERK1/2 expressions. Combinatorial treatment of LP and genistein exerted protective action against hepatic inflammation and fibrosis by means of a quite similar mechanism [265].

\subsection{Astaxanthin (AX)}

Astaxanthin (12) is a xanthophyll carotenoid compound belonging to the broad chemical class of terpenoids. It is widely found in marine species like algae, yeast, salmon, trout, krill, shrimp and crayfish [51]. AX possesses a wide range of anti-inflammatory and antioxidant activities, with 550-fold more potency than vitamin E [266,267].

$\mathrm{AX}$ has been reported to possess anti-inflammatory and antioxidant activities, whereby it enhanced Nrf2 activity and reduced mRNA expression of IL- 6 and IL- $1 \beta$ by suppressing NF- $\kappa$ B p65 nuclear expression [268]. A recent review reported that the antioxidant capacity of AX was highly dependent on the modulation of several signaling pathway proteins, including Nrf2, PI3K/AKT, JAK/STAT-3, NF-kB, MAPKs and PPAR $\gamma$ [269]. This same group of signaling pathways were implicated in other reviews summarizing the protective effect of AX against various cancers [270,271]. AX upregulated the nuclear expression of Nrf2, which inhibited the proliferation and progression of K562 human leukemia cells [272]. In contrast, it reduced LPS-induced inflammation and oxidative stress by inhibiting the activation of Nrf2 in U937 human myeloid leukemia cells [273]. The previous two reports suggested that AX possessed both an activating and an inhibitory role for Nrf2 in the management of human leukemia. The Nrf2 inhibitory role of AX might be associated with the administration of high doses in test animals [274]. In LNCaP prostate cancer cells, AX epigenetically produced an ameliorative effect by mediating upregulated mRNA and protein expression of Nrf2, NQO1 and GSTP1 [275]. In hepatocellular carcinoma cells, AX induced anti-tumor action through marked suppression of NF- $\mathrm{B}$ p 65 and Wnt/ $\beta$ catenin, and negative activation of PI3K/AKT and ERK signaling [276]. Mechanistically, the inhibition of oral cancer by AX also took place by a quite similar mechanism [277]. AX was found to be effective against human colon cancer, whereby it induced apoptosis by suppressing the phosphorylation of AKT and enhancing the phosphorylation of p38, JNK, and ERK1/2 [278]. In HUVECs, AX caused Nrf2 nuclear translocation and enhanced the mRNA levels of HO-1, NQO1 and Gpx [279,280]. Mechanistically, in this case, AX mediated ERK phosphorylation and activated ARE-driven luciferase activity to exert its antioxidant effect. In addition, activation of PTEN/AKT signaling was also reported in the Nrf2 driven antioxidant activity of AX in HUVECs. Low concentrations of AX with polyunsaturated fatty acids synergistically resulted in a marked decrease in oxidative stress by upregulating Nrf2/ ARE signaling [281]. In SKOV3 ovarian cancer cells, AX in combination with human serum albumin produced a better anticancer effect and overcame drug resistance by suppressing the NF- $\mathrm{BB}$ and activating p53 and MAPKs signaling [282].

In myeloid-derived suppressor cells (MDSCs), AX induced Nrf2 and its antioxidant enzyme expressions, thus causing maturation of MDSCs and regulating the immunosuppressive tumor environment in mice [283]. Notably, MDSCs are immature myeloid cells that are aggregated in stress conditions like tumor. Inflammatory pathway proteins NF- $\mathrm{B}$ and COX-2 were effectively downregulated by AX in ameliorating esophageal cancer [284]. 
AX improved cyclophosphamide-mediated oxidative stress, DNA damage and hepatocarcinogenesis in rats via induction of Nrf2 and phase-II enzymes NQO-1 and HO-1 [285]. Here, it markedly downregulated the $\mathrm{p} 53$ and p38 expressions. In lying hens, it ameliorated oxidative stress by upregulating Nrf2, SOD1, SOD2 and Gpx4 [286]. It showed anti-colon cancer activity in vivo by abrogating the NF- $\mathrm{KB}, \mathrm{COX}-2$ and increasing the AKT and ERK-2 expressions [287]. The chemopreventive potential of AX was found to be prominent in hamster buccal pouch carcinoma, where it suppressed JAK2/STAT3 signaling, particularly the phosphorylation and consequent nuclear translocation of STAT3 [288]. Doxorubicinand ochratoxin-induced liver injury was improved by AX through activating Nrf2, degrading Keap1, and upregulating HO-1 and Mn-SOD expressions [289,290]. Here, ERK level was increased and NF- $\mathrm{kB}$ level was decreased by AX. Figure 8 represents the mechanism of Nrf2-ARE activation by AX.
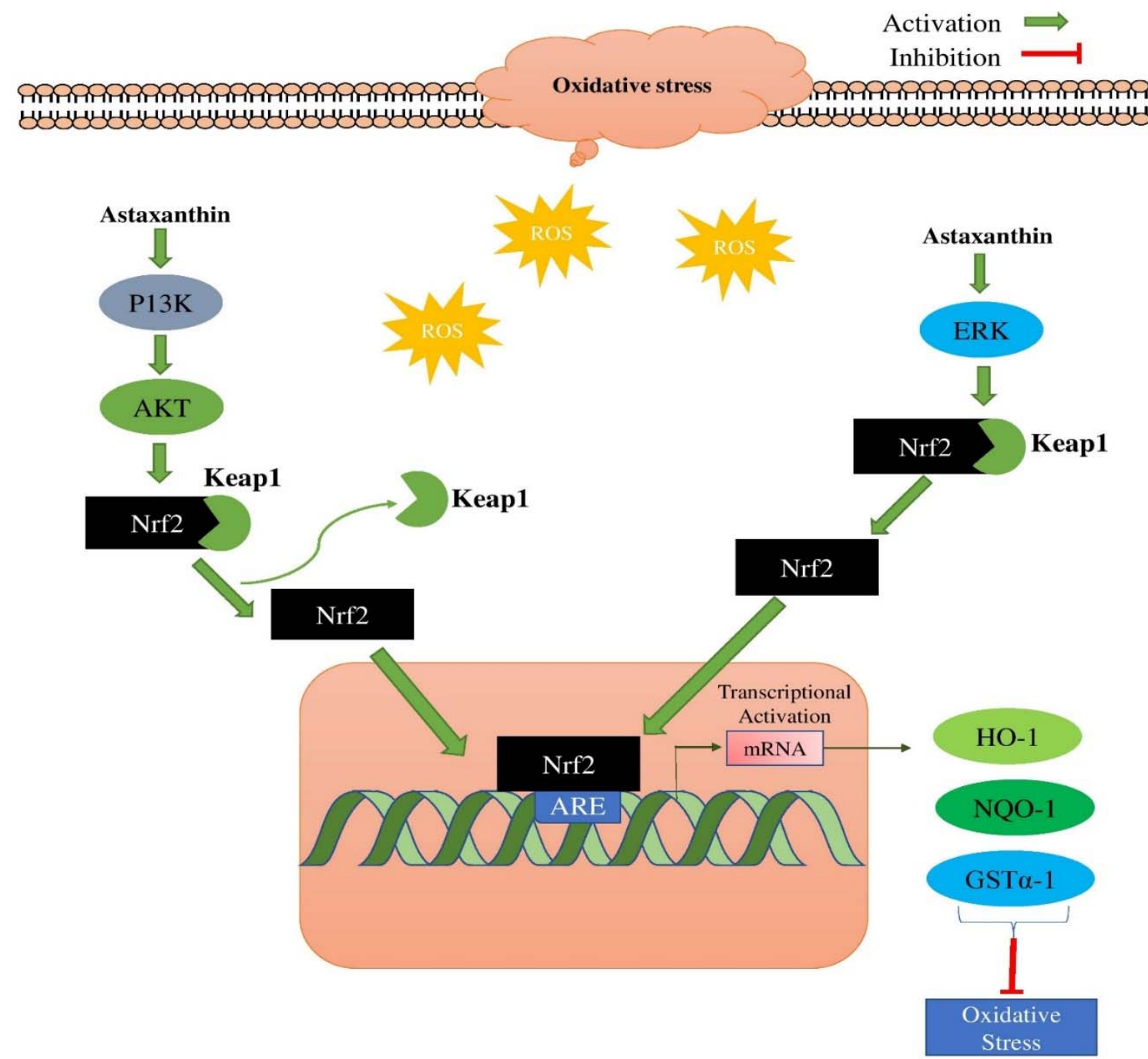

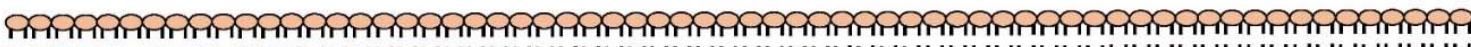

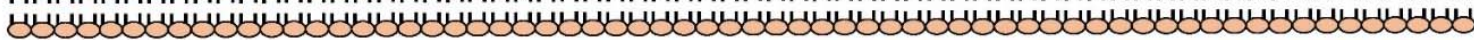

Figure 8. Mechanism of Nrf2-ARE activation by AX. The diagram was adapted and modified from Wu, H. et al., 2015 [291]. 


\subsection{Fucoxanthin (FX)}

Fucoxanthin (13) is the most abundant marine carotenoid extracted from seaweeds and microalgae [52].

FX exhibited anti-inflammatory and antioxidant effects in RAW 264.7 cells by activating the Nrf2, which was induced by activated PI3K/AKT signaling [292]. In addition, expressions of inflammatory markers including IL-6, IL-1 $\beta$, and TNF- $\alpha$ were suppressed by FX. It demonstrated chemoresistant activity in HepG2-C8 human hepatocarcinoma cells by upregulating the mRNA and protein levels of Nrf2, ARE luciferase activity, NQO1, HO-1, and SOD [293]. The same study demonstrated another potential mechanism of FX in preventing oxidative stress and cancer, whereby epigenetic changes to Nrf2 DNA methylation occurred, altering the gene expressions without changing the DNA composition. In contrast, a study reported that the Nrf2/ARE-mediated antioxidant action of FX was partially mediated by its pro-oxidant activity [294]. Here, FX-treated mouse hepatic BNL CL.2 cells demonstrated a marked rise in cellular ROS generation. In the same study, FX enhanced the binding of Nrf2 with ARE, upregulated the mRNA and protein expression of HO-1, NQO1 and phosphorylation of ERK and p38. However, in HepG2 liver cancer cells, FX caused suppression of antioxidant enzymes SOD1, SOD2, CAT and downregulation of AKT1, ERK1/2, and JNK signaling in order to mediate its anticancer effect [295]. Here, generation of ROS by FX increased oxidative stress, which helped to destroy the liver cancer cells by means of an apoptotic mechanism. It exerted cytoprotective activity against $\mathrm{H}_{2} \mathrm{O}_{2}$-mediated oxidative insult in L02 hepatic cells by PI3K-regulated increases in Nrf2, HO-1 and NQO1 expressions [296]. The effects of a combined therapy of FX and rosmarinic acid were evaluated on cell viability, apoptosis induction, inflammasome regulation, and anti-oxidative response activation in UVB-irradiated HaCaT keratinocytes [297]. This combination (1:1) demonstrated improved antioxidant and anti-inflammatory profiles, with FX facilitating Nrf2 nuclear translocation and ARE-mediated activation of its detoxifying enzymes [297]. Furthermore, this combination suppressed the inflammatory response by downregulating the NLR family pyrin domain containing 3 (NLRP3), apoptosis-associated speck-like Protein (ASC), and IL-1 $\beta$ expression. Again, in human keratinocytes, FX substantially facilitated Nrf2 activation and its binding to AREs, which in turn increased the mRNA and protein levels of GSH, GCLC and glutathione synthetase (GSS) [298]. This upregulated Nrf2 activity was accompanied by increased PI3K/AKT signaling. FX enhanced the sensitivity of cisplatin to HepG2 hepatoma cells by downregulating the NF- $\mathrm{kB}$ expression [299]. Here, the phosphorylation of ERK, p38 and PI3K/AKT signaling was attenuated by FX.

The oxidative stress suppressing effect of FX was also evident in a study in which FX treatment in experimental rats enhanced the mRNA expression of Nrf2 and NQO1 [300]. Moreover, expressions of CAT and Gpx were also increased in FX-treated rats. Alcoholmediated oxidative injury and inflammation were ameliorated by FX through activation of Nrf2 and suppression of TLR4-induced NF-kB signaling [301]. Promotion of Nrf2 and SOD and suppression of TNF- $\alpha$ action were implicated in ameliorating pathogen-associated molecular pattern-induced inflammation by FX [302]. A recent review reported that signaling pathways like PI3K/AKT/Nrf2, ERK, AMPK/AKT/cAMP response element binding protein (CREB) / peroxisome proliferator-activated receptor-gamma coactivator- $1 \alpha$ (PGC$1 \alpha$ ), and Nrf2-autophagy were involved in FX-induced anti-inflammatory response [303]. Figure 9 presents the mechanism of Nrf2-ARE activation by FX. 


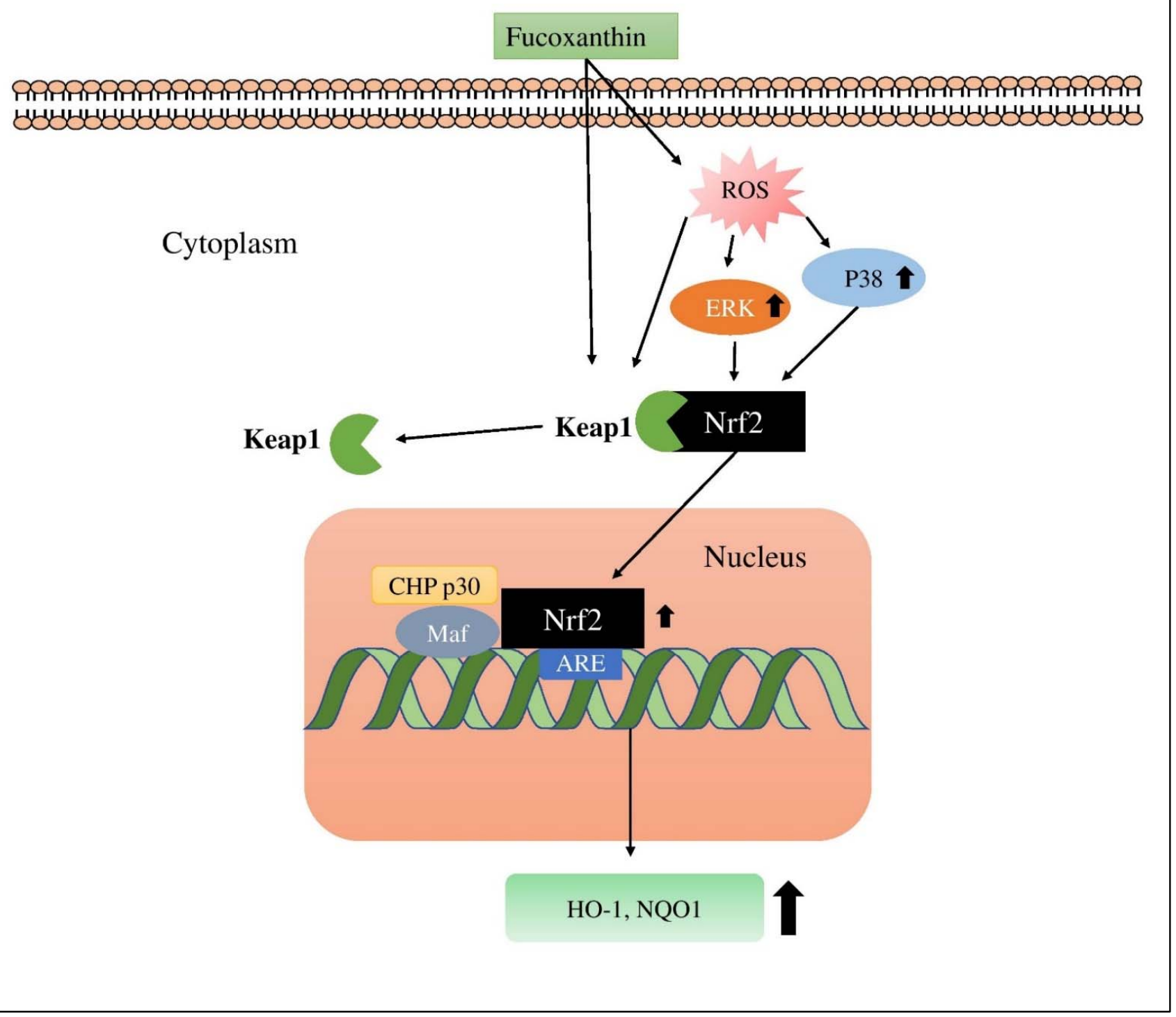

Figure 9. Mechanism of Nrf2-ARE activation by FX. The diagram was adapted and modified from Liu, C.-L. et al., 2011 [294].

\section{Conclusions and Future Perspective}

The health benefits of dietary supplements containing terpenenoids are well established. Reportedly, terpenes are strong candidates for the prevention of inflammation and carcinoma, as evidenced by a large number of in vitro cell line and in vivo animal-based studies. Usually, these dietary constituents do not destroy the ROS in vivo by directly reacting with them. Instead, they directly or indirectly boost body's defense mechanism by modulating the Keap1-Nrf2-ARE signaling system, which is able to regulate the expressions antioxidant genes, phase I and II detoxification enzymes, chaperones, growth factors and their receptors, transport proteins, proteasome subunits, and some other transcription factors (Table 3) [64]. As the incidence of different types of cancers is on the rise, dietary supplements containing terpenoids may lead to more promising preventive therapies for the prevention of cancer occurrence. This review would like to add that there are still a lot of existing areas of investigation for terpenoids with respect to cancer prevention. Researchers and nutritionists should pay more attention to the study of dietary terpenoid compounds and their possible use in the prevention of cancers. Considering these thirteen compounds, there the evidence of chemopreventive activity in animal mod- 
els and especially in humans is still insufficient. It can be suggested that further animaland human-based studies are indeed necessary to reconfirm and clinically establish the chemopreventive nature of the terpenoids. Focus can also be given towards using dietary terpenoids in patients who are already suffering from cancer with a view to restricting the further progression of cancer. This kind of epidemiological approach could be critical for assessing the practical chemopreventive nature of the terpenoids on a case-by-case basis. Because of the widespread abundance of antioxidative properties in dietary terpenoids, the inclusion of these in regular food diets might help a great deal in alleviating the incidence of diseases like cancer and inflammation.

Table 3. Cellular signaling and targeted downstream proteins of dietary terpenoids.

\begin{tabular}{|c|c|c|c|c|}
\hline $\begin{array}{l}\text { Compound } \\
\text { Number }\end{array}$ & Compound Name & $\begin{array}{c}\text { Proteins Modulated } \\
\text { Keap1-Nrf2-ARE System }\end{array}$ & $\begin{array}{l}\text { Proteins Modulated after } \\
\text { Nrf2 Activation/Inhibition }\end{array}$ & References \\
\hline 1 & Zerumbone & $\begin{array}{c}\text { p38 MAPK, AKT /PI3K, ERK, } \\
\text { JNK, PKC, AMPK }\end{array}$ & $\mathrm{HO}-1, \gamma-\mathrm{GCLC}$, and Gpx & {$[78,86,90]$} \\
\hline 2 & Khayandirobilide A & p38 MAPK & $\mathrm{HO}-1$ & {$[40]$} \\
\hline 3 & Brusatol & $\begin{array}{l}\text { HER2/AKT/ERK1/2, } \\
\text { PI3K/AKT/mTOR, }\end{array}$ & $\begin{array}{l}\text { HO-1, NQO1, GSTm2, } \\
\text { and GCLC }\end{array}$ & {$[102,122]$} \\
\hline 4 & Withaferin A & $\begin{array}{l}\text { ERK1/2, JNK, p38 MAPK, } \\
\text { AKT/mTOR, JAK/STAT }\end{array}$ & $\begin{array}{l}\text { HO-1, NQO1, GSR, CAT, } \\
\text { SOD1, and TXN }\end{array}$ & {$[131,132,137]$} \\
\hline 5 & Betulin & $\begin{array}{c}\text { AMPK/AKT/GSK-3 } \beta \\
\text { MAPK, AhR }\end{array}$ & $\begin{array}{l}\text { NADPH, NQO1, HO-1, GCLC, } \\
\text { GCLM, Gpx, CAT and SOD }\end{array}$ & {$[145,148]$} \\
\hline 6 & Ganodermanondiol & ERK, JNK, p38 MAPK, AMPK & GSH, GCL, HO-1 & {$[45,151,158]$} \\
\hline 7 & Oleanolic acid & $\begin{array}{c}\text { p62, NF-kB, ERK, } \\
\text { PI3K/AKT, MAPKs }\end{array}$ & $\begin{array}{l}\text { SOD-1, NQO1, GCL, } \\
\text { GCLC, HO-1 } \\
\text { HO-1, NOO1, GST, }\end{array}$ & {$[170,171,180,184]$} \\
\hline 8 & Ursolic acid & NF-kB, AKT, JNK & $\begin{array}{l}\text { UDP-glucuronosyltransferase } \\
\text { 1A1, GSTT }\end{array}$ & {$[192,194,198,202,205]$} \\
\hline 9 & Dioscin & $\begin{array}{c}\text { Sirt1/FOXO1/NF-кB, IкB } \alpha, \\
\text { FXR/AMPK, } \\
\text { TGF- } \beta / \text { Smad, p38 MAPK }\end{array}$ & $\begin{array}{l}\text { HO-1, GST, NQO1, } \\
\text { GCLC, GCLM }\end{array}$ & {$[217,218,222,224]$} \\
\hline 10 & Corosolic acid & JNK, AMPK & HO-1, NQO1, GCLC & {$[233,240]$} \\
\hline 11 & Lycopene & $\begin{array}{c}\text { NF-kB, JNK, STAT3, } \\
\text { AKT/mTOR, p62 }\end{array}$ & $\begin{array}{l}\text { HO-1, NQO1, GSH, CAT, SOD, } \\
\text { GCL, GST- } \pi \text {, Gpx }\end{array}$ & {$[245,252,255-258]$} \\
\hline 12 & Astaxanthin & $\begin{array}{c}\text { NF-kB p65, Wnt/ } \beta \text {-catenin, } \\
\text { PI3K/AKT, ERK, JAK2/STAT3, } \\
\text { p53, p38 }\end{array}$ & $\begin{array}{l}\text { NQO1, HO-1, SOD1, } \\
\text { SOD2, Gpx4 }\end{array}$ & {$[276,285,286,288]$} \\
\hline 13 & Fucoxanthin & $\begin{array}{c}\text { AKT1, ERK1/2, JNK, NF-кB, } \\
\text { p38, PI3K/AKT }\end{array}$ & $\begin{array}{l}\text { NQO1, HO-1, SOD1, } \\
\text { SOD2, CAT }\end{array}$ & {$[293,295,299]$} \\
\hline
\end{tabular}

Author Contributions: M.A.S. has conceptualized the idea, write the manuscript and thoroughly reviewed the write-up. M.A.I. has collected data, drawn the tables and wrote the article. M.A.A.F. has collected data and drawn the figures. H.R.K. collected the data and has critically reviewed the article. M.A.S., J.X. and J.S.-G. have guided throughout the work and reviewed all the given information. All authors have read and agreed to the published version of the manuscript.

Funding: This review article is not funded from any source.

Conflicts of Interest: The authors declare no conflict of interest.

\section{References}

1. Siegel, R.L.; Miller, K.D.; Jemal, A. Cancer statistics, 2020. CA Cancer J. Clin. 2020, 70, 7-30. [CrossRef] [PubMed]

2. Mayne, S.T.; Playdon, M.C.; Rock, C.L. Diet, nutrition, and cancer: Past, present and future. Nat. Rev. Clin. Oncol. 2016, 13, 504-515. [CrossRef] [PubMed]

3. Kensler, T.W.; Spira, A.; Garber, J.E.; Szabo, E.; Lee, J.J.; Dong, Z.; Dannenberg, A.J.; Hait, W.N.; Blackburn, E.; Davidson, N.E. Transforming cancer prevention through precision medicine and immune-oncology. Cancer Prev. Res. 2016, 9, 2-10. [CrossRef]

4. Beeken, R.; Williams, K.; Wardle, J.; Croker, H. “What about diet?" A qualitative study of cancer survivors' views on diet and cancer and their sources of information. Eur. J. Cancer Care 2016, 25, 774-783. [CrossRef] 
5. Kłósek, M.; Kuropatnicki, A.K.; Szliszka, E.; Korzonek-Szlacheta, I.; Król, W. Chalcones Target the Tumor Necrosis Factor-Related Apoptosis-Inducing Ligand (TRAIL) Signaling Pathway for Cancer Chemoprevention. In Nutrition and Functional Foods for Healthy Aging; Elsevier: Amsterdam, The Netherlands, 2017; pp. 233-244.

6. $\quad$ Ruddon, R.W. Cancer Biology; Oxford University Press: Oxford, UK, 2007.

7. Huang, H.; Zhang, G.; Zhou, Y.; Lin, C.; Chen, S.; Lin, Y.; Mai, S.; Huang, Z. Reverse screening methods to search for the protein targets of chemopreventive compounds. Front. Chem. 2018, 6, 138. [CrossRef] [PubMed]

8. Kikuchi, H.; Yuan, B.; Hu, X.; Okazaki, M. Chemopreventive and anticancer activity of flavonoids and its possibility for clinical use by combining with conventional chemotherapeutic agents. Am. J. Cancer Res. 2019, 9, 1517. [PubMed]

9. Rather, R.A.; Bhagat, M. Cancer chemoprevention and piperine: Molecular mechanisms and therapeutic opportunities. Front. Cell Dev. Biol. 2018, 6, 10. [CrossRef]

10. Hayes, J.D.; Dinkova-Kostova, A.T.; Tew, K.D. Oxidative stress in cancer. Cancer Cell 2020, 38, 167-197. [CrossRef]

11. Dodson, M.; Castro-Portuguez, R.; Zhang, D.D. NRF2 plays a critical role in mitigating lipid peroxidation and ferroptosis. Redox Biol. 2019, 23, 101107. [CrossRef]

12. Redza-Dutordoir, M.; Averill-Bates, D.A. Activation of apoptosis signalling pathways by reactive oxygen species. Biochim. Biophys. Acta (BBA)-Mol. Cell Res. 2016, 1863, 2977-2992. [CrossRef]

13. Wang, X.; Saud, S.M.; Zhang, X.; Li, W.; Hua, B. Protective effect of Shaoyao Decoction against colorectal cancer via the Keap1-Nrf2-ARE signaling pathway. J. Ethnopharmacol. 2019, 241, 111981. [CrossRef] [PubMed]

14. Wu, W.L.; Papagiannakopoulos, T. The pleiotropic role of the KEAP1/NRF2 pathway in cancer. Annu. Rev. Cancer Biol. 2020, 4, 413-435. [CrossRef]

15. Jiang, G.; Liang, X.; Huang, Y.; Lan, Z.; Zhang, Z.; Su, Z.; Fang, Z.; Lai, Y.; Yao, W.; Liu, T. p62 promotes proliferation, apoptosisresistance and invasion of prostate cancer cells through the Keap1/Nrf2/ARE axis. Oncol. Rep. 2020, 43, 1547-1557. [CrossRef] [PubMed]

16. Arora, D.; Jaglan, S. Nanocarriers based delivery of nutraceuticals for cancer prevention and treatment: A review of recent research developments. Trends Food Sci. Technol. 2016, 54, 114-126. [CrossRef]

17. Gingras, D.; Béliveau, R. Colorectal cancer prevention through dietary and lifestyle modifications. Cancer Microenviron. 2011, 4, 133-139. [CrossRef]

18. Kudryavtseva, A.; Krasnov, G.; Lipatova, A.; Alekseev, B.; Maganova, F.; Shaposhnikov, M.; Fedorova, M.; Snezhkina, A.; Moskalev, A. Effects of Abies sibirica terpenes on cancer-and aging-associated pathways in human cells. Oncotarget 2016, 7, 83744. [CrossRef]

19. Cichewicz, R.H.; Kouzi, S.A. Chemistry, biological activity, and chemotherapeutic potential of betulinic acid for the prevention and treatment of cancer and HIV infection. Med. Res. Rev. 2004, 24, 90-114. [CrossRef]

20. Fulda, S. Betulinic acid for cancer treatment and prevention. Int. J. Mol. Sci. 2008, 9, 1096-1107. [CrossRef]

21. Zhang, Y.; Jiang, P.; Ye, M.; Kim, S.-H.; Jiang, C.; Lü, J. Tanshinones: Sources, pharmacokinetics and anti-cancer activities. Int. J. Mol. Sci. 2012, 13, 13621-13666. [CrossRef] [PubMed]

22. Cox-Georgian, D.; Ramadoss, N.; Dona, C.; Basu, C. Therapeutic and medicinal uses of terpenes. In Medicinal Plants; Springer: Berlin/Heidelberg, Germany, 2019; pp. 333-359.

23. Li, A.-L.; Shen, T.; Wang, T.; Zhou, M.-X.; Wang, B.; Song, J.-T.; Zhang, P.-L.; Wang, X.-L.; Ren, D.-M.; Lou, H.-X. Novel diterpenoidtype activators of the Keap1/Nrf2/ARE signaling pathway and their regulation of redox homeostasis. Free Radic. Biol. Med. 2019, 141, 21-33. [CrossRef]

24. Pichersky, E.; Raguso, R.A. Why do plants produce so many terpenoid compounds? New Phytol. 2018, 220, 692-702. [CrossRef]

25. Christianson, D.W. Structural and chemical biology of terpenoid cyclases. Chem. Rev. 2017, 117, 11570-11648. [CrossRef]

26. Sharma, S.H.; Thulasingam, S.; Nagarajan, S. Terpenoids as anti-colon cancer agents-A comprehensive review on its mechanistic perspectives. Eur. J. Pharmacol. 2017, 795, 169-178. [CrossRef] [PubMed]

27. Gonzalez-Burgos, E.; Gómez-Serranillos, M. Terpene compounds in nature: A review of their potential antioxidant activity. Curr. Med. Chem. 2012, 19, 5319-5341. [CrossRef]

28. Holstein, S.A.; Tong, H.; Kuder, C.H.; Hohl, R.J. Quantitative determination of geranyl diphosphate levels in cultured human cells. Lipids 2009, 44, 1055-1062. [CrossRef] [PubMed]

29. Neighbors, J.D. The mevalonate pathway and terpenes: A diversity of chemopreventatives. Curr. Pharmacol. Rep. 2018, 4, 157-169. [CrossRef]

30. Crane, F.L. Biochemical functions of coenzyme Q10. J. Am. Coll. Nutr. 2001, 20, 591-598. [CrossRef]

31. Burda, P.; Aebi, M. The dolichol pathway of N-linked glycosylation. Biochim. Biophys. Acta (BBA)-Gen. Subj. 1999, 1426, $239-257$. [CrossRef]

32. Norat, T.; Scoccianti, C.; Boutron-Ruault, M.-C.; Anderson, A.; Berrino, F.; Cecchini, M.; Espina, C.; Key, T.; Leitzmann, M.; Powers, H. European code against cancer 4th edition: Diet and cancer. Cancer Epidemiol. 2015, 39, S56-S66. [CrossRef]

33. Cragg, G.M.; Newman, D.J. Plants as a source of anti-cancer agents. J. Ethnopharmacol. 2005, 100, 72-79. [CrossRef]

34. Srivastava, V.; Negi, A.S.; Kumar, J.; Gupta, M.; Khanuja, S.P. Plant-based anticancer molecules: A chemical and biological profile of some important leads. Bioorg. Med. Chem. 2005, 13, 5892-5908. [CrossRef]

35. Cragg, G.; Newman, D. Plants as a source of anti-cancer and anti-HIV agents. Ann. Appl. Biol. 2003, 143, 127-133. [CrossRef] 
36. Weindruch, R.; Albanes, D.; Kritchevsky, D. The role of calories and caloric restriction in carcinogenesis. Hematol./Oncol. Clin. 1991, 5, 79-89. [CrossRef]

37. Prasad, S.; Gupta, S.C.; Tyagi, A.K. Reactive oxygen species (ROS) and cancer: Role of antioxidative nutraceuticals. Cancer Lett. 2017, 387, 95-105. [CrossRef] [PubMed]

38. De Mejia, E.G.; Dia, V.P. The role of nutraceutical proteins and peptides in apoptosis, angiogenesis, and metastasis of cancer cells. Cancer Metastasis Rev. 2010, 29, 511-528. [CrossRef] [PubMed]

39. Nakamura, Y.; Yoshida, C.; Murakami, A.; Ohigashi, H.; Osawa, T.; Uchida, K. Zerumbone, a tropical ginger sesquiterpene, activates phase II drug metabolizing enzymes. FEBS Lett. 2004, 572, 245-250. [CrossRef] [PubMed]

40. Zhou, M.-M.; Zhang, W.-Y.; Li, R.-J.; Guo, C.; Wei, S.-S.; Tian, X.-M.; Luo, J.; Kong, L.-Y. Anti-inflammatory activity of Khayandirobilide A from Khaya senegalensis via NF- $\mathrm{B}$, AP-1 and p38 MAPK/Nrf2/HO-1 signaling pathways in lipopolysaccharidestimulated RAW 264.7 and BV-2 cells. Phytomedicine 2018, 42, 152-163. [CrossRef] [PubMed]

41. Nie, Y.L.; Liu, K.X.; Mao, X.Y.; Li, Y.L.; Li, J.; Zhang, M.M. Effect of injection of Brucea javanica oil emulsion plus chemoradiotherapy for lung cancer: A review of clinical evidence. J. Evid.-Based Med. 2012, 5, 216-225. [CrossRef] [PubMed]

42. Cai, S.J.; Liu, Y.; Han, S.; Yang, C. Brusatol, an NRF2 inhibitor for future cancer therapeutic. Cell Biosci. 2019, 9, 1-3. [CrossRef] [PubMed]

43. Gupta, G.L.; Rana, A. Withania somnifera (Ashwagandha): A review. Pharmacogn. Rev. 2007, 1, 129-136.

44. Alakurtti, S.; Mäkelä, T.; Koskimies, S.; Yli-Kauhaluoma, J. Pharmacological properties of the ubiquitous natural product betulin. Eur. J. Pharm. Sci. 2006, 29, 1-13. [CrossRef]

45. Li, B.; Lee, D.-S.; Kang, Y.; Yao, N.-Q.; An, R.-B.; Kim, Y.-C. Protective effect of ganodermanondiol isolated from the Lingzhi mushroom against tert-butyl hydroperoxide-induced hepatotoxicity through Nrf2-mediated antioxidant enzymes. Food Chem. Toxicol. 2013, 53, 317-324. [CrossRef]

46. Žiberna, L.; Šamec, D.; Mocan, A.; Nabavi, S.F.; Bishayee, A.; Farooqi, A.A.; Sureda, A.; Nabavi, S.M. Oleanolic acid alters multiple cell signaling pathways: Implication in cancer prevention and therapy. Int. J. Mol. Sci. 2017, 18, 643. [CrossRef]

47. Frighetto, R.T.; Welendorf, R.M.; Nigro, E.N.; Frighetto, N.; Siani, A.C. Isolation of ursolic acid from apple peels by high speed counter-current chromatography. Food Chem. 2008, 106, 767-771. [CrossRef]

48. Yang, L.; Ren, S.; Xu, F.; Ma, Z.; Liu, X.; Wang, L. Recent advances in the pharmacological activities of dioscin. BioMed Res. Int. 2019, 2019, 5763602. [CrossRef] [PubMed]

49. Sung, B.; Kang, Y.J.; Kim, D.H.; Hwang, S.Y.; Lee, Y.; Kim, M.; Yoon, J.-H.; Kim, C.M.; Chung, H.Y.; Kim, N.D. Corosolic acid induces apoptotic cell death in HCT116 human colon cancer cells through a caspase-dependent pathway. Int. J. Mol. Med. 2014, 33, 943-949. [CrossRef] [PubMed]

50. Chen, D.; Huang, C.; Chen, Z. A review for the pharmacological effect of lycopene in central nervous system disorders. Biomed. Pharmacother. 2019, 111, 791-801. [CrossRef] [PubMed]

51. Ambati, R.R.; Phang, S.-M.; Ravi, S.; Aswathanarayana, R.G. Astaxanthin: Sources, extraction, stability, biological activities and its commercial applications-A review. Mar. Drugs 2014, 12, 128-152. [CrossRef] [PubMed]

52. Miyashita, K.; Nishikawa, S.; Beppu, F.; Tsukui, T.; Abe, M.; Hosokawa, M. The allenic carotenoid fucoxanthin, a novel marine nutraceutical from brown seaweeds. J. Sci. Food Agric. 2011, 91, 1166-1174. [CrossRef] [PubMed]

53. Su, X.; Jiang, X.; Meng, L.; Dong, X.; Shen, Y.; Xin, Y. Anticancer activity of sulforaphane: The epigenetic mechanisms and the Nrf2 signaling pathway. Oxid. Med. Cell. Longev. 2018, 2018, 5438179. [CrossRef]

54. Ramos-Gomez, M.; Kwak, M.-K.; Dolan, P.M.; Itoh, K.; Yamamoto, M.; Talalay, P.; Kensler, T.W. Sensitivity to carcinogenesis is increased and chemoprotective efficacy of enzyme inducers is lost in nrf2 transcription factor-deficient mice. Proc. Natl. Acad. Sci. USA 2001, 98, 3410-3415. [CrossRef]

55. Satoh, H.; Moriguchi, T.; Taguchi, K.; Takai, J.; Maher, J.M.; Suzuki, T.; Winnard, P.T., Jr.; Raman, V.; Ebina, M.; Nukiwa, T. Nrf2-deficiency creates a responsive microenvironment for metastasis to the lung. Carcinogenesis 2010, 31, 1833-1843. [CrossRef]

56. Basak, P.; Sadhukhan, P.; Sarkar, P.; Sil, P.C. Perspectives of the Nrf-2 signaling pathway in cancer progression and therapy. Toxicol. Rep. 2017, 4, 306-318. [CrossRef]

57. Li, C.; Cheng, L.; Wu, H.; He, P.; Zhang, Y.; Yang, Y.; Chen, J.; Chen, M. Activation of the KEAP1-NRF2-ARE signaling pathway reduces oxidative stress in Hep2 cells. Mol. Med. Rep. 2018, 18, 2541-2550. [CrossRef]

58. Tebay, L.E.; Robertson, H.; Durant, S.T.; Vitale, S.R.; Penning, T.M.; Dinkova-Kostova, A.T.; Hayes, J.D. Mechanisms of activation of the transcription factor Nrf2 by redox stressors, nutrient cues, and energy status and the pathways through which it attenuates degenerative disease. Free Radic. Biol. Med. 2015, 88, 108-146. [CrossRef] [PubMed]

59. Kang, M.-I.; Kobayashi, A.; Wakabayashi, N.; Kim, S.-G.; Yamamoto, M. Scaffolding of Keap1 to the actin cytoskeleton controls the function of Nrf2 as key regulator of cytoprotective phase 2 genes. Proc. Natl. Acad. Sci. USA 2004, 101, 2046-2051. [CrossRef] [PubMed]

60. Chapple, S.J.; Siow, R.C.; Mann, G.E. Crosstalk between Nrf2 and the proteasome: Therapeutic potential of Nrf2 inducers in vascular disease and aging. Int. J. Biochem. Cell Biol. 2012, 44, 1315-1320. [CrossRef]

61. Achiwa, Y.; Hasegawa, K.; Udagawa, Y. Regulation of the phosphatidylinositol 3-kinase-Akt and the mitogen-activated protein kinase pathways by ursolic acid in human endometrial cancer cells. Biosci. Biotechnol. Biochem. 2007, 71, 0612070208. [CrossRef]

62. Hayes, J.D.; Dinkova-Kostova, A.T. The Nrf2 regulatory network provides an interface between redox and intermediary metabolism. Trends Biochem. Sci. 2014, 39, 199-218. [CrossRef] 
63. Priestley, J.R.; Kautenburg, K.E.; Casati, M.C.; Endres, B.T.; Geurts, A.M.; Lombard, J.H. The NRF2 knockout rat: A new animal model to study endothelial dysfunction, oxidant stress, and microvascular rarefaction. Am. J. Physiol.-Heart Circ. Physiol. 2016, 310, H478-H487. [CrossRef]

64. Zeraik, M.; Yariwake, J. Quantification of isoorientin and total flavonoids in Passiflora edulis fruit pulp by HPLC-UV/DAD. Microchem. J. 2010, 96, 86-91. [CrossRef]

65. Itoh, K.; Tong, K.I.; Yamamoto, M. Molecular mechanism activating Nrf2-Keap1 pathway in regulation of adaptive response to electrophiles. Free Radic. Biol. Med. 2004, 36, 1208-1213. [CrossRef]

66. Kwak, M.-K.; Wakabayashi, N.; Kensler, T.W. Chemoprevention through the Keap1-Nrf2 signaling pathway by phase 2 enzyme inducers. Mutat. Res./Fundam. Mol. Mech. Mutagen. 2004, 555, 133-148. [CrossRef] [PubMed]

67. Zhang, D.D. Mechanistic studies of the Nrf2-Keap1 signaling pathway. Drug Metab. Rev. 2006, 38, 769-789. [CrossRef]

68. Shin, J.M.; Lee, K.-M.; Lee, H.J.; Yun, J.H.; Nho, C.W. Physalin A regulates the Nrf2 pathway through ERK and p38 for induction of detoxifying enzymes. BMC Complement. Altern. Med. 2019, 19, 101. [CrossRef] [PubMed]

69. Li, Y.; Xu, J.; Li, D.; Ma, H.; Mu, Y.; Huang, X.; Li, L. Guavinoside B from Psidium guajava alleviates acetaminophen-induced liver injury via regulating the Nrf2 and JNK signaling pathways. Food Funct. 2020, 11, 8297-8308. [CrossRef] [PubMed]

70. Cho, H.-Y.; Gladwell, W.; Wang, X.; Chorley, B.; Bell, D.; Reddy, S.P.; Kleeberger, S.R. Nrf2-regulated PPAR $\gamma$ expression is critical to protection against acute lung injury in mice. Am. J. Respir. Crit. Care Med. 2010, 182, 170-182. [CrossRef]

71. Liu, G.-H.; Qu, J.; Shen, X. NF-кB/p65 antagonizes Nrf2-ARE pathway by depriving CBP from Nrf2 and facilitating recruitment of HDAC3 to MafK. Biochim. Biophys. Acta (BBA)-Mol. Cell Res. 2008, 1783, 713-727. [CrossRef] [PubMed]

72. Wardyn, J.D.; Ponsford, A.H.; Sanderson, C.M. Dissecting molecular cross-talk between Nrf2 and NF- $\mathrm{kB}$ response pathways. Biochem. Soc. Trans. 2015, 43, 621-626. [CrossRef] [PubMed]

73. Rotblat, B.; Melino, G.; Knight, R.A. NRF2 and p53: Januses in cancer? Oncotarget 2012, 3, 1272. [CrossRef]

74. Naidu, S.D.; Kostov, R.V.; Dinkova-Kostova, A.T. Transcription factors Hsf1 and Nrf2 engage in crosstalk for cytoprotection. Trends Pharmacol. Sci. 2015, 36, 6-14. [CrossRef]

75. Silva-Islas, C.A.; Maldonado, P.D. Canonical and non-canonical mechanisms of Nrf2 activation. Pharmacol. Res. 2018, 134, 92-99. [CrossRef]

76. Prasannan, R.; Kalesh, K.A.; Shanmugam, M.K.; Nachiyappan, A.; Ramachandran, L.; Nguyen, A.H.; Kumar, A.P.; Lakshmanan, M.; Ahn, K.S.; Sethi, G. Key cell signaling pathways modulated by zerumbone: Role in the prevention and treatment of cancer. Biochem. Pharmacol. 2012, 84, 1268-1276. [CrossRef] [PubMed]

77. Ohnishi, K.; Irie, K.; Murakami, A. In vitro covalent binding proteins of zerumbone, a chemopreventive food factor. Biosci. Biotechnol. Biochem. 2009, 73, 0907061526. [CrossRef] [PubMed]

78. Hosseini, N.; Khoshnazar, A.; Saidijam, M.; Azizi Jalilian, F.; Najafi, R.; Mahdavinezhad, A.; Ezati, R.; Sotanian, A.; Amini, R. Zerumbone Suppresses Human Colorectal Cancer Invasion and Metastasis via Modulation of FAk/PI3k/NFkB-uPA Pathway. Nutr. Cancer 2019, 71, 159-171. [CrossRef] [PubMed]

79. Zhao, J.; Guan, J.-L. Signal transduction by focal adhesion kinase in cancer. Cancer Metastasis Rev. 2009, 28, 35-49. [CrossRef] [PubMed]

80. Hauck, C.R.; Hsia, D.A.; Schlaepfer, D.D. The focal adhesion kinase-A regulator of cell migration and invasion. IUBMB Life 2002, 53, 115-119. [CrossRef] [PubMed]

81. Ferrari, D.; Speciale, A.; Cristani, M.; Fratantonio, D.; Molonia, M.S.; Ranaldi, G.; Saija, A.; Cimino, F. Cyanidin-3-O-glucoside inhibits NF-kB signalling in intestinal epithelial cells exposed to TNF- $\alpha$ and exerts protective effects via Nrf2 pathway activation. Toxicol. Lett. 2016, 264, 51-58. [CrossRef] [PubMed]

82. Tsuboi, K.; Matsuo, Y.; Shamoto, T.; Shibata, T.; Koide, S.; Morimoto, M.; Guha, S.; Sung, B.; Aggarwal, B.B.; Takahashi, H. Zerumbone inhibits tumor angiogenesis via NF-kB in gastric cancer. Oncol. Rep. 2014, 31, 57-64. [CrossRef] [PubMed]

83. Haque, M.A.; Jantan, I.; Arshad, L.; Bukhari, S.N.A. Exploring the immunomodulatory and anticancer properties of zerumbone. Food Funct. 2017, 8, 3410-3431. [CrossRef]

84. Tang, C.; Bi, M.; Yu, H.; Chen, W.; Wang, J. Zerumbone protects HEK 293 cells from irradiation-induced DNA damage via activating Keap1/Nrf2/ARE pathway. Afr. J. Pharm. Pharmacol. 2011, 5, 2247-2254.

85. Kim, M.-J.; Yun, J.-M. Molecular mechanism of the protective effect of zerumbone on lipopolysaccharide-induced inflammation of THP-1 cell-derived macrophages. J. Med. Food 2019, 22, 62-73. [CrossRef] [PubMed]

86. Yang, H.-L.; Lee, C.-L.; Korivi, M.; Liao, J.-W.; Rajendran, P.; Wu, J.-J.; Hseu, Y.-C. Zerumbone protects human skin keratinocytes against UVA-irradiated damages through Nrf2 induction. Biochem. Pharmacol. 2018, 148, 130-146. [CrossRef] [PubMed]

87. Hseu, Y.-C.; Lo, H.-W.; Korivi, M.; Tsai, Y.-C.; Tang, M.-J.; Yang, H.-L. Dermato-protective properties of ergothioneine through induction of Nrf2/ARE-mediated antioxidant genes in UVA-irradiated Human keratinocytes. Free Radic. Biol. Med. 2015, 86, 102-117. [CrossRef] [PubMed]

88. Hirota, A.; Kawachi, Y.; Itoh, K.; Nakamura, Y.; Xu, X.; Banno, T.; Takahashi, T.; Yamamoto, M.; Otsuka, F. Ultraviolet A irradiation induces NF-E2-related factor 2 activation in dermal fibroblasts: Protective role in UVA-induced apoptosis. J. Investig. Dermatol. 2005, 124, 825-832. [CrossRef] [PubMed]

89. Zimta, A.-A.; Cenariu, D.; Irimie, A.; Magdo, L.; Nabavi, S.M.; Atanasov, A.G.; Berindan-Neagoe, I. The role of Nrf2 activity in cancer development and progression. Cancers 2019, 11, 1755. [CrossRef] 
90. Hseu, Y.-C.; Chang, C.-T.; Gowrisankar, Y.V.; Chen, X.-Z.; Lin, H.-C.; Yen, H.-R.; Yang, H.-L. Zerumbone Exhibits Antiphotoaging and Dermatoprotective Properties in Ultraviolet A-Irradiated Human Skin Fibroblast Cells via the Activation of Nrf2/ARE Defensive Pathway. Oxid. Med. Cell. Longev. 2019, 2019, 4098674. [CrossRef]

91. Shin, J.-W.; Murakami, A.; Ohigashi, H.; Johnson, D.; Johnson, J.; Na, H.-K.; Surh, Y.-J. Zerumbone, a Sesquiterpene Derived from Tropical Ginger, Induces Heme Oxygenase-1 Expression via Activation of Nrf2 Signaling in Mouse Epidermal Cells and Hairless Mouse Skin In Vivo; American Association for Cancer Rresearch: Philadelphia, PA, USA, 2008.

92. Leung, W.-S.; Yang, M.-L.; Lee, S.-S.; Kuo, C.-W.; Ho, Y.-C.; Huang-Liu, R.; Lin, H.-W.; Kuan, Y.-H. Protective effect of zerumbone reduces lipopolysaccharide-induced acute lung injury via antioxidative enzymes and Nrf2/HO-1 pathway. Int. Immunopharmacol. 2017, 46, 194-200. [CrossRef]

93. Wang, M.; Niu, J.; Ou, L.; Deng, B.; Wang, Y.; Li, S. Zerumbone protects against carbon tetrachloride (CC14)-induced acute liver injury in mice via inhibiting oxidative stress and the inflammatory response: Involving the TLR4/NF-kB/COX-2 pathway. Molecules 2019, 24, 1964. [CrossRef]

94. Lee, C.-Y.; Chen, S.-P.; Su, C.-H.; Ho, Y.-C.; Yang, M.-L.; Lee, S.-S.; Huang-Liu, R.; Yang, C.-P.; Chen, C.-J.; Kuan, Y.-H. Zerumbone from Zingiber zerumbet ameliorates lipopolysaccharide-induced ICAM-1 and cytokines expression via p38 MAPK/JNK-IKB/NFкB pathway in mouse model of acute lung injury. Chin. J. Physiol. 2018, 61, 171-180. [CrossRef]

95. Shin, J.-W.; Ohnishi, K.; Murakami, A.; Lee, J.-S.; Kundu, J.K.; Na, H.-K.; Ohigashi, H.; Surh, Y.-J. Zerumbone induces heme oxygenase-1 expression in mouse skin and cultured murine epidermal cells through activation of Nrf2. Cancer Prev. Res. 2011, 4, 860-870. [CrossRef] [PubMed]

96. Bours, V.; Dejardin, E.; Goujon-Letawe, F.; Merville, M.-P.; Castronovo, V. The NF-kB transcription factor and cancer: High expression of NF-кB-and IкB-related proteins in tumor cell lines. Biochem. Pharmacol. 1994, 47, 145-149. [CrossRef]

97. Dejardin, E.; Bonizzi, G.; Bellahcene, A.; Castronovo, V.; Merville, M.-P.; Bours, V. Highly-expressed p100/p52 (NFKB2) sequesters other NF-kB-related proteins in the cytoplasm of human breast cancer cells. Oncogene 1995, 11, 1835-1841. [PubMed]

98. Nakshatri, H.; Bhat-Nakshatri, P.; Martin, D.A.; Goulet, R.J.; Sledge, G.W. Constitutive activation of NF-kappaB during progression of breast cancer to hormone-independent growth. Mol. Cell. Biol. 1997, 17, 3629-3639. [CrossRef]

99. Young, M.R.; Yang, H.-S.; Colburn, N.H. Promising molecular targets for cancer prevention: AP-1, NF-kB and Pdcd4. Trends Mol. Med. 2003, 9, 36-41. [CrossRef]

100. Reuter, S.; Gupta, S.C.; Chaturvedi, M.M.; Aggarwal, B.B. Oxidative stress, inflammation, and cancer: How are they linked? Free Radic. Biol. Med. 2010, 49, 1603-1616. [CrossRef]

101. Ren, D.; Villeneuve, N.F.; Jiang, T.; Wu, T.; Lau, A.; Toppin, H.A.; Zhang, D.D. Brusatol enhances the efficacy of chemotherapy by inhibiting the Nrf2-mediated defense mechanism. Proc. Natl. Acad. Sci. USA 2011, 108, 1433-1438. [CrossRef]

102. Yang, Y.; Tian, Z.; Guo, R.; Ren, F. Nrf2 Inhibitor, Brusatol in Combination with Trastuzumab Exerts Synergistic Antitumor Activity in HER2-Positive Cancers by Inhibiting Nrf2/HO-1 and HER2-AKT/ERK1/2 Pathways. Oxid. Med. Cell. Longev. 2020, 2020, 9867595. [CrossRef] [PubMed]

103. Fan, R.; Wang, Y.; Wang, Y.; Wei, L.; Zheng, W. Mechanism of progestin resistance in endometrial precancer/cancer through Nrf2-survivin pathway. Am. J. Transl. Res. 2017, 9, 1483.

104. Wu, T.; Harder, B.G.; Wong, P.K.; Lang, J.E.; Zhang, D.D. Oxidative stress, mammospheres and Nrf2-new implication for breast cancer therapy? Mol. Carcinog. 2015, 54, 1494-1502. [CrossRef]

105. Murakami, Y.; Sugiyama, K.; Ebinuma, H.; Nakamoto, N.; Ojiro, K.; Chu, P.-S.; Taniki, N.; Saito, Y.; Teratani, T.; Koda, Y. Dual effects of the Nrf2 inhibitor for inhibition of hepatitis C virus and hepatic cancer cells. BMC Cancer 2018, 18, 1-14. [CrossRef]

106. Wang, M.; Shi, G.; Bian, C.; Nisar, M.F.; Guo, Y.; Wu, Y.; Li, W.; Huang, X.; Jiang, X.; Bartsch, J.W. UVA irradiation enhances Brusatol-mediated inhibition of melanoma growth by downregulation of the Nrf2-mediated antioxidant response. Oxid. Med. Cell. Longev. 2018, 2018, 9742154. [CrossRef] [PubMed]

107. Guo, S.; Zhang, J.; Wei, C.; Lu, Z.; Cai, R.; Pan, D.; Zhang, H.; Liang, B.; Zhang, Z. Anticancer effects of brusatol in nasopharyngeal carcinoma through suppression of the Akt/mTOR signaling pathway. Cancer Chemother. Pharmacol. 2020, 85, 1097-1108. [CrossRef] [PubMed]

108. Cheng, C.; Yuan, F.; Chen, X.-P.; Zhang, W.; Zhao, X.-L.; Jiang, Z.-P.; Zhou, H.-H.; Zhou, G.; Cao, S. Inhibition of Nrf2mediated glucose metabolism by brusatol synergistically sensitizes acute myeloid leukemia to Ara-C. Biomed. Pharmacother. 2021, 142, 111652. [CrossRef]

109. Olayanju, A.; Copple, I.M.; Bryan, H.K.; Edge, G.T.; Sison, R.L.; Wong, M.W.; Lai, Z.-Q.; Lin, Z.-X.; Dunn, K.; Sanderson, C.M. Brusatol provokes a rapid and transient inhibition of Nrf2 signaling and sensitizes mammalian cells to chemical toxicityImplications for therapeutic targeting of Nrf2. Free Radic. Biol. Med. 2015, 78, 202-212. [CrossRef]

110. Zhou, J.; Tan, L.; Xie, J.; Lai, Z.; Huang, Y.; Qu, C.; Luo, D.; Lin, Z.; Huang, P.; Su, Z. Characterization of brusatol selfmicroemulsifying drug delivery system and its therapeutic effect against dextran sodium sulfate-induced ulcerative colitis in mice. Drug Deliv. 2017, 24, 1667-1679. [CrossRef]

111. Park, S.-H.; Kim, J.H.; Ko, E.; Kim, J.-Y.; Park, M.-J.; Kim, M.J.; Seo, H.; Li, S.; Lee, J.-Y. Resistance to gefitinib and cross-resistance to irreversible EGFR-TKIs mediated by disruption of the Keap1-Nrf2 pathway in human lung cancer cells. FASEB J. 2018, 32, 5862-5873. [CrossRef] 
112. Xiang, Y.; Ye, W.; Huang, C.; Lou, B.; Zhang, J.; Yu, D.; Huang, X.; Chen, B.; Zhou, M. Brusatol inhibits growth and induces apoptosis in pancreatic cancer cells via JNK/p38 MAPK/NF-kb/Stat3/Bcl-2 signaling pathway. Biochem. Biophys. Res. Commun. 2017, 487, 820-826. [CrossRef]

113. Lee, J.H.; Rangappa, S.; Mohan, C.D.; Sethi, G.; Lin, Z.-X.; Rangappa, K.S.; Ahn, K.S. Brusatol, a Nrf2 inhibitor targets STAT3 signaling cascade in head and neck squamous cell carcinoma. Biomolecules 2019, 9, 550. [CrossRef]

114. Chen, H.; Jiang, T.; Chen, H.; Su, J.; Wang, X.; Cao, Y.; Li, Q. Brusatol reverses lipopolysaccharide-induced epithelial-mesenchymal transformation and induces apoptosis through PI3K/Akt/NF-кB pathway in human gastric cancer SGC-7901 cells. Anticancer Drugs 2021, 32, 394-404. [CrossRef]

115. Chandrasekaran, J.; Balasubramaniam, J.; Sellamuthu, A.; Ravi, A. An in vitro study on the reversal of epithelial to mesenchymal transition by brusatol and its synergistic properties in triple-negative breast cancer cells. J. Pharm. Pharmacol. 2021, 73, 749-757. [CrossRef] [PubMed]

116. Zhou, J.; Hou, J.; Wang, J.; Wang, J.; Gao, J. Brusatol Inhibits Laryngeal Cancer Cell Proliferation and Metastasis via Abrogating JAK2/STAT3 Signaling Mediated Epithelial-Mesenchymal Transition; Research Square: Durham, NC, USA, 2021.

117. Lee, J.H.; Mohan, C.D.; Deivasigamani, A.; Jung, Y.Y.; Rangappa, S.; Basappa, S.; Chinnathambi, A.; Alahmadi, T.A.; Alharbi, S.A.; Garg, M. Brusatol suppresses STAT3-driven metastasis by downregulating epithelial-mesenchymal transition in hepatocellular carcinoma. J. Adv. Res. 2020, 26, 83-94. [CrossRef] [PubMed]

118. Illangeswaran, R.S.S.; Karathedath, S.; Rajamani, B.M.; Balasubramanian, P. Global Gene Expression Analysis Reveals Genotoxic Effect of Nrf2 Pharmacological Inhibitor Brusatol in Myeloid Leukemia Cells-a Promising Novel Anticancer Agent. Blood 2018, 132, 5150. [CrossRef]

119. Xiang, Y.; Ye, W.; Huang, C.; Yu, D.; Chen, H.; Deng, T.; Zhang, F.; Lou, B.; Zhang, J.; Shi, K. Brusatol enhances the chemotherapy efficacy of gemcitabine in pancreatic cancer via the Nrf2 signalling pathway. Oxid. Med. Cell. Longev. 2018, 2018, 2360427. [CrossRef]

120. Evans, J.P.; Winiarski, B.K.; Sutton, P.A.; Jones, R.P.; Ressel, L.; Duckworth, C.A.; Pritchard, D.M.; Lin, Z.-X.; Vicky, F.L.; Tweedle, E.M. The Nrf2 inhibitor brusatol is a potent antitumour agent in an orthotopic mouse model of colorectal cancer. Oncotarget 2018, 9, 27104. [CrossRef]

121. Yu, X.-Q.; Shang, X.-Y.; Huang, X.-X.; Yao, G.-D.; Song, S.-J. Brusatol: A potential anti-tumor quassinoid from Brucea javanica. Chin. Herb. Med. 2020, 12, 359-366. [CrossRef]

122. Liu, X.; Xu, H.; Zhang, Y.; Wang, P.; Gao, W. Brusatol inhibits amyloid- $\beta$-induced neurotoxicity in U-251 cells via regulating the Nrf2/HO-1 pathway. J. Cell. Biochem. 2019, 120, 10556-10563. [CrossRef] [PubMed]

123. Sova, M.; Saso, L. Design and development of Nrf2 modulators for cancer chemoprevention and therapy: A review. Drug Des. Dev. Ther. 2018, 12, 3181. [CrossRef]

124. Mohan, R.; Hammers, H.; Bargagna-Mohan, P.; Zhan, X.; Herbstritt, C.; Ruiz, A.; Zhang, L.; Hanson, A.; Conner, B.; Rougas, J. Withaferin A is a potent inhibitor of angiogenesis. Angiogenesis 2004, 7, 115-122. [CrossRef] [PubMed]

125. Hahm, E.-R.; Kim, S.-H.; Singh, K.B.; Singh, K.; Singh, S.V. A comprehensive review and perspective on anticancer mechanisms of withaferin A in breast cancer. Cancer Prev. Res. 2020, 13, 721-734. [CrossRef] [PubMed]

126. Sivasankarapillai, V.S.; Madhu Kumar Nair, R.; Rahdar, A.; Bungau, S.; Zaha, D.C.; Aleya, L.; Tit, D.M. Overview of the anticancer activity of Withaferin A, an active constituent of the Indian Ginseng Withania somnifera. Environ. Sci. Pollut. Res. 2020, 27, 26025-26035. [CrossRef]

127. Lee, I.-C.; Choi, B.Y. Withaferin-A-A natural anticancer agent with pleitropic mechanisms of action. Int. J. Mol. Sci. 2016, 17, 290. [CrossRef]

128. Dom, M.; Berghe, W.V.; Van Ostade, X. Broad-spectrum antitumor properties of Withaferin A: A proteomic perspective. RSC Med. Chem. 2020, 11, 30-50. [CrossRef]

129. Hahm, E.R.; Kim, S.H.; Singh, K.B.; Singh, S.V. RNA-seq reveals novel cancer-selective and disease subtype-independent mechanistic targets of withaferin A in human breast cancer cells. Mol. Carcinog. 2021, 60, 3-14. [CrossRef] [PubMed]

130. Palliyaguru, D.L.; Chartoumpekis, D.V.; Wakabayashi, N.; Skoko, J.J.; Yagishita, Y.; Singh, S.V.; Kensler, T.W. Withaferin A induces Nrf2-dependent protection against liver injury: Role of Keap1-independent mechanisms. Free Radic. Biol. Med. 2016, 101, 116-128. [CrossRef] [PubMed]

131. Yu, T.-J.; Tang, J.-Y.; Ou-Yang, F.; Wang, Y.-Y.; Yuan, S.-S.F.; Tseng, K.; Lin, L.-C.; Chang, H.-W. Low concentration of withaferin A inhibits oxidative stress-mediated migration and invasion in oral cancer cells. Biomolecules 2020, 10, 777. [CrossRef]

132. Chien, T.-M.; Wu, K.-H.; Chuang, Y.-T.; Yeh, Y.-C.; Wang, H.-R.; Yeh, B.-W.; Yen, C.-H.; Yu, T.-J.; Wu, W.-J.; Chang, H.-W. Withaferin a Triggers Apoptosis and DNA Damage in Bladder Cancer J82 Cells through Oxidative Stress. Antioxidants 2021, 10, 1063. [CrossRef] [PubMed]

133. Sun, G.Y.; Li, R.; Cui, J.; Hannink, M.; Gu, Z.; Fritsche, K.L.; Lubahn, D.B.; Simonyi, A. Withania somnifera and its withanolides attenuate oxidative and inflammatory responses and up-regulate antioxidant responses in BV-2 microglial cells. Neuromol. Med. 2016, 18, 241-252. [CrossRef]

134. Eggler, A.L.; Gay, K.A.; Mesecar, A.D. Molecular mechanisms of natural products in chemoprevention: Induction of cytoprotective enzymes by Nrf2. Mol. Nutr. Food Res. 2008, 52, S84-S94. [CrossRef] [PubMed]

135. Jadeja, R.N.; Urrunaga, N.H.; Dash, S.; Khurana, S.; Saxena, N.K. Withaferin-A reduces acetaminophen-induced liver injury in mice. Biochem. Pharmacol. 2015, 97, 122-132. [CrossRef] 
136. Logie, E.; Vanden Berghe, W. Tackling Chronic Inflammation with Withanolide Phytochemicals-A Withaferin A Perspective. Antioxidants 2020, 9, 1107. [CrossRef]

137. Shiragannavar, V.D.; Gowda, N.G.S.; Kumar, D.P.; Mirshahi, F.; Santhekadur, P.K. Withaferin A Acts as a Novel Regulator of Liver $X$ Receptor- $\alpha$ in HCC. Front. Oncol. 2021, 10, 3124. [CrossRef]

138. Kyakulaga, A.H.; Aqil, F.; Munagala, R.; Gupta, R.C. Withaferin a inhibits epithelial to mesenchymal transition in non-small cell lung cancer cells. Sci. Rep. 2018, 8, 1-14.

139. Chung, S.S.; Wu, Y.; Okobi, Q.; Adekoya, D.; Atefi, M.; Clarke, O.; Dutta, P.; Vadgama, J.V. Proinflammatory cytokines IL-6 and TNF- $\alpha$ increased telomerase activity through NF- $\mathrm{kB} / \mathrm{STAT} 1 / \mathrm{STAT} 3$ activation, and withaferin A inhibited the signaling in colorectal cancer cells. Mediat. Inflamm. 2017, 2017, 5958429. [CrossRef] [PubMed]

140. Król, S.K.; Kiełbus, M.; Rivero-Müller, A.; Stepulak, A. Comprehensive review on betulin as a potent anticancer agent. BioMed Res. Int. 2015, 2015, 584189. [CrossRef]

141. Li, Y.; He, K.; Huang, Y.; Zheng, D.; Gao, C.; Cui, L.; Jin, Y.H. Betulin induces mitochondrial cytochrome c release associated apoptosis in human cancer cells. Mol. Carcinog. 2010, 49, 630-640. [CrossRef]

142. Yim, N.-H.; Jung, Y.P.; Kim, A.; Kim, T.; Ma, J.Y. Induction of apoptotic cell death by betulin in multidrug-resistant human renal carcinoma cells. Oncol. Rep. 2015, 34, 1058-1064. [CrossRef] [PubMed]

143. So, H.M.; Eom, H.J.; Lee, D.; Kim, S.; Kang, K.S.; Lee, I.K.; Baek, K.-H.; Park, J.Y.; Kim, K.H. Bioactivity evaluations of betulin identified from the bark of Betula platyphylla var. japonica for cancer therapy. Arch. Pharm. Res. 2018, 41, 815-822. [CrossRef] [PubMed]

144. Hordyjewska, A.; Ostapiuk, A.; Horecka, A. Betulin and betulinic acid in cancer research. J. Pre-Clin. Clin. Res. 2018, 12, 72-75. [CrossRef]

145. Ci, X.; Zhou, J.; Lv, H.; Yu, Q.; Peng, L.; Hua, S. Betulin exhibits anti-inflammatory activity in LPS-stimulated macrophages and endotoxin-shocked mice through an AMPK/AKT/Nrf2-dependent mechanism. Cell Death Dis. 2017, 8, e2798. [CrossRef]

146. Kumar, H.; Kim, I.-S.; More, S.V.; Kim, B.-W.; Choi, D.-K. Natural product-derived pharmacological modulators of Nrf2/ARE pathway for chronic diseases. Nat. Prod. Rep. 2014, 31, 109-139. [CrossRef]

147. Zhao, H.; Liu, Z.; Liu, W.; Han, X.; Zhao, M. Betulin attenuates lung and liver injuries in sepsis. Int. Immunopharmacol. 2016, 30, 50-56. [CrossRef] [PubMed]

148. Zhang, J.; Zhou, B.; Sun, J.; Chen, H.; Yang, Z. Betulin ameliorates 7,12-dimethylbenz (a) anthracene-induced rat mammary cancer by modulating MAPK and AhR/Nrf-2 signaling pathway. J. Biochem. Mol. Toxicol. 2021, 35, e22779. [CrossRef]

149. Dai, J.; Miller, M.A.; Everetts, N.J.; Wang, X.; Li, P.; Li, Y.; Xu, J.-H.; Yao, G. Elimination of quiescent slow-cycling cells via reducing quiescence depth by natural compounds purified from Ganoderma lucidum. Oncotarget 2017, 8, 13770. [CrossRef]

150. Lee, Y.-H.; Kim, J.-H.; Song, C.-H.; Jang, K.-J. Ethanol extract of Ganoderma lucidum augments cellular anti-oxidant defense through activation of Nrf2/HO-1. J. Pharm. 2016, 19, 59.

151. Li, P.; Liu, L.; Huang, S.; Zhang, Y.; Xu, J.; Zhang, Z. Anti-cancer effects of a neutral triterpene fraction from Ganoderma lucidum and its active constituents on SW620 human colorectal cancer cells. Anti-Cancer Agents Med. Chem. (Former. Curr. Med. Chem.-Anti-Cancer Agents) 2020, 20, 237-244. [CrossRef] [PubMed]

152. Trang, T.T.T.; Cuong, T.D.; Thu, N.V.; Woo, M.H.; Min, B.S. Cytotoxic triterpenoids from the fruiting bodies of Ganoderma lucidum. Nat. Prod. Sci. 2014, 20,7-12.

153. Jedinak, A.; Thyagarajan-Sahu, A.; Jiang, J.; Sliva, D. Ganodermanontriol, a lanostanoid triterpene from Ganoderma lucidum, suppresses growth of colon cancer cells through ss-catenin signaling. Int. J. Oncol. 2011, 38, 761-767. [PubMed]

154. Jiang, J.; Jedinak, A.; Sliva, D. Ganodermanontriol (GDNT) exerts its effect on growth and invasiveness of breast cancer cells through the down-regulation of CDC20 and uPA. Biochem. Biophys. Res. Commun. 2011, 415, 325-329. [CrossRef] [PubMed]

155. Chen, S.; Li, X.; Yong, T.; Wang, Z.; Su, J.; Jiao, C.; Xie, Y.; Yang, B.B. Cytotoxic lanostane-type triterpenoids from the fruiting bodies of Ganoderma lucidum and their structure-activity relationships. Oncotarget 2017, 8, 10071. [CrossRef]

156. Zheng, D.S.; Chen, L.S. Triterpenoids from Ganoderma lucidum inhibit the activation of EBV antigens as telomerase inhibitors. Exp. Ther. Med. 2017, 14, 3273-3278. [CrossRef]

157. Wu, M.; Shen, C.-E.; Lin, Q.-F.; Zhong, J.-Y.; Zhou, Y.-F.; Liu, B.-C.; Xu, J.-H.; Zhang, Z.-Q.; Li, P. Sterols and triterpenoids from Ganoderma lucidum and their reversal activities of tumor multidrug resistance. Nat. Prod. Res. 2021, 1-4. [CrossRef] [PubMed]

158. Kim, J.-W.; Kim, H.-I.; Kim, J.-H.; Kwon, O.; Son, E.-S.; Lee, C.-S.; Park, Y.-J. Effects of ganodermanondiol, a new melanogenesis inhibitor from the medicinal mushroom Ganoderma lucidum. Int. J. Mol. Sci. 2016, 17, 1798. [CrossRef] [PubMed]

159. Pollier, J.; Goossens, A. Oleanolic acid. Phytochemistry 2012, 77, 10-15. [CrossRef]

160. Liese, J.; Abhari, B.A.; Fulda, S. Smac mimetic and oleanolic acid synergize to induce cell death in human hepatocellular carcinoma cells. Cancer Lett. 2015, 365, 47-56. [CrossRef]

161. Lúcio, K.A.; da Graça Rocha, G.; Monção-Ribeiro, L.C.; Fernandes, J.; Takiya, C.M.; Gattass, C.R. Oleanolic acid initiates apoptosis in non-small cell lung cancer cell lines and reduces metastasis of a B16F10 melanoma model in vivo. PLoS ONE 2011, 6, e28596. [CrossRef]

162. Wu, J.; Yang, C.; Guo, C.; Li, X.; Yang, N.; Zhao, L.; Hang, H.; Liu, S.; Chu, P.; Sun, Z. SZC015, a synthetic oleanolic acid derivative, induces both apoptosis and autophagy in MCF-7 breast cancer cells. Chem.-Biol. Interact. 2016, 244, 94-104. [CrossRef]

163. Mu, D.-W.; Guo, H.-Q.; Zhou, G.-B.; Li, J.-Y.; Su, B. Oleanolic acid suppresses the proliferation of human bladder cancer by Akt/mTOR/S6K and ERK1/2 signaling. Int. J. Clin. Exp. Pathol. 2015, 8, 13864. [PubMed] 
164. Wei, J.; Liu, M.; Liu, H.; Wang, H.; Wang, F.; Zhang, Y.; Han, L.; Lin, X. Oleanolic acid arrests cell cycle and induces apoptosis via ROS-mediated mitochondrial depolarization and lysosomal membrane permeabilization in human pancreatic cancer cells. $J$. Appl. Toxicol. 2013, 33, 756-765. [CrossRef]

165. Zhang, P.; Li, H.; Chen, D.; Ni, J.; Kang, Y.; Wang, S. Oleanolic acid induces apoptosis in human leukemia cells through caspase activation and poly (ADP-ribose) polymerase cleavage. Acta Biochim. Biophys. Sin. 2007, 39, 803-809. [CrossRef] [PubMed]

166. Guo, G.; Yao, W.; Zhang, Q.; Bo, Y. Oleanolic acid suppresses migration and invasion of malignant glioma cells by inactivating MAPK/ERK signaling pathway. PLoS ONE 2013, 8, e72079.

167. Li, H.-F.; Wang, X.-A.; Xiang, S.-S.; Hu, Y.-P.; Jiang, L.; Shu, Y.-J.; Li, M.-L.; Wu, X.-S.; Zhang, F.; Ye, Y.-Y. Oleanolic acid induces mitochondrial-dependent apoptosis and G0/G1 phase arrest in gallbladder cancer cells. Drug Des. Dev. Ther. 2015, 9, 3017. [CrossRef]

168. Niu, G.; Sun, L.; Pei, Y.; Wang, D. Oleanolic acid inhibits colorectal cancer angiogenesis by blocking the VEGFR2 signaling pathway. Anti-Cancer Agents Med. Chem. (Former. Curr. Med. Chem.-Anti-Cancer Agents) 2018, 18, 583-590. [CrossRef] [PubMed]

169. Liu, J.; Wu, Q.; Lu, Y.-F.; Pi, J. New insights into generalized hepatoprotective effects of oleanolic acid: Key roles of metallothionein and Nrf2 induction. Biochem. Pharmacol. 2008, 76, 922-928. [CrossRef]

170. Castrejón-Jiménez, N.S.; Leyva-Paredes, K.; Baltierra-Uribe, S.L.; Castillo-Cruz, J.; Campillo-Navarro, M.; Hernández-Pérez, A.D.; Luna-Angulo, A.B.; Chacón-Salinas, R.; Coral-Vázquez, R.M.; Estrada-García, I. Ursolic and oleanolic acids induce mitophagy in A549 human lung cancer cells. Molecules 2019, 24, 3444. [CrossRef]

171. Narożna, M.; Krajka-Kuźniak, V.; Bednarczyk-Cwynar, B.; Kucińska, M.; Kleszcz, R.; Kujawski, J.; Piotrowska-Kempisty, H.; Plewiński, A.; Murias, M.; Baer-Dubowska, W. Conjugation of Diclofenac with Novel Oleanolic Acid Derivatives Modulate Nrf2 and NF-кB Activity in Hepatic Cancer Cells and Normal Hepatocytes Leading to Enhancement of Its Therapeutic and Chemopreventive Potential. Pharmaceuticals 2021, 14, 688. [CrossRef] [PubMed]

172. Narożna, M.; Krajka-Kuźniak, V.; Bednarczyk-Cwynar, B.; Kleszcz, R.; Baer-Dubowska, W. The Effect of Novel Oleanolic Acid Oximes Conjugated with Indomethacin on the Nrf2-ARE And NF-kB Signaling Pathways in Normal Hepatocytes and Human Hepatocellular Cancer Cells. Pharmaceuticals 2021, 14, 32. [CrossRef] [PubMed]

173. Narożna, M.; Krajka-Kuźniak, V.; Kleszcz, R.; Bednarczyk-Cwynar, B.; Szaefer, H.; Baer-Dubowska, W. Activation of the Nrf2 response by oleanolic acid oxime morpholide (3-hydroxyiminoolean-12-en-28-oic acid morpholide) is associated with its ability to induce apoptosis and inhibit proliferation in HepG2 hepatoma cells. Eur. J. Pharmacol. 2020, 883, 173307. [CrossRef]

174. Liu, J.; Zheng, L.; Wu, N.; Ma, L.; Zhong, J.; Liu, G.; Lin, X. Oleanolic acid induces metabolic adaptation in cancer cells by activating the AMP-activated protein kinase pathway. J. Agric. Food Chem. 2014, 62, 5528-5537. [CrossRef]

175. Wang, X.; Ye, X.-L.; Liu, R.; Chen, H.-L.; Bai, H.; Liang, X.; Zhang, X.-D.; Wang, Z.; Li, W.-L.; Hai, C.-X. Antioxidant activities of oleanolic acid in vitro: Possible role of Nrf2 and MAP kinases. Chem.-Biol. Interact. 2010, 184, 328-337. [CrossRef]

176. Shanmugam, M.K.; Dai, X.; Kumar, A.P.; Tan, B.K.; Sethi, G.; Bishayee, A. Oleanolic acid and its synthetic derivatives for the prevention and therapy of cancer: Preclinical and clinical evidence. Cancer Lett. 2014, 346, 206-216. [CrossRef]

177. Lee, D.-H.; Lee, J.; Jeon, J.; Kim, K.-J.; Yun, J.-H.; Jeong, H.-S.; Lee, E.H.; Koh, Y.J.; Cho, C.-H. Oleanolic acids inhibit vascular endothelial growth factor receptor 2 signaling in endothelial cells: Implication for anti-angiogenic therapy. Mol. Cells 2018, 41,771 .

178. Hosny, S.; Sahyon, H.; Youssef, M.; Negm, A. Oleanolic acid suppressed dmba-induced liver carcinogenesis through induction of mitochondrial-mediated apoptosis and autophagy. Nutr. Cancer 2021, 73, 968-982. [CrossRef]

179. Xin, C.; Liu, S.; Qu, H.; Wang, Z. The novel nanocomplexes containing deoxycholic acid-grafted chitosan and oleanolic acid displays the hepatoprotective effect against CCl4-induced liver injury in vivo. Int. J. Biol. Macromol. 2021, 185, 338-349. [CrossRef] [PubMed]

180. Reisman, S.A.; Aleksunes, L.M.; Klaassen, C.D. Oleanolic acid activates Nrf2 and protects from acetaminophen hepatotoxicity via Nrf2-dependent and Nrf2-independent processes. Biochem. Pharmacol. 2009, 77, 1273-1282. [CrossRef]

181. Liu, J.; Lu, Y.F.; Wu, Q.; Xu, S.F.; Shi, F.G.; Klaassen, C.D. Oleanolic acid reprograms the liver to protect against hepatotoxicants, but is hepatotoxic at high doses. Liver Int. 2019, 39, 427-439. [CrossRef]

182. Liu, J.; Ma, L.; Chen, X.; Wang, J.; Yu, T.; Gong, Y.; Ma, A.; Zheng, L.; Liang, H. ERK inhibition sensitizes cancer cells to oleanolic acid-induced apoptosis through ERK/Nrf2/ROS pathway. Tumor Biol. 2016, 37, 8181-8187. [CrossRef]

183. Hwang, Y.-J.; Song, J.; Kim, H.-R.; Hwang, K.-A. Oleanolic acid regulates NF- $\mathrm{B}$ signaling by suppressing MafK expression in RAW 264.7 cells. BMB Rep. 2014, 47, 524. [CrossRef]

184. Jin, J.; He, H.; Zhang, X.; Wu, R.; Gan, L.; Li, D.; Lu, Y.; Wu, P.; Wong, W.-L.; Zhang, K. The in vitro and in vivo study of oleanolic acid indole derivatives as novel anti-inflammatory agents: Synthesis, biological evaluation, and mechanistic analysis. Bioorg. Chem. 2021, 113, 104981. [CrossRef] [PubMed]

185. Liobikas, J.; Majiene, D.; Trumbeckaite, S.; Kursvietiene, L.; Masteikova, R.; Kopustinskiene, D.M.; Savickas, A.; Bernatoniene, J. Uncoupling and antioxidant effects of ursolic acid in isolated rat heart mitochondria. J. Nat. Prod. 2011, 74, 1640-1644. [CrossRef] [PubMed]

186. Wang, B.; Cao, W.; Biswal, S.; Doré, S. Carbon monoxide-activated Nrf2 pathway leads to protection against permanent focal cerebral ischemia. Stroke 2011, 42, 2605-2610. [CrossRef] 
187. Checker, R.; Sandur, S.K.; Sharma, D.; Patwardhan, R.S.; Jayakumar, S.; Kohli, V.; Sethi, G.; Aggarwal, B.B.; Sainis, K.B. Potent anti-inflammatory activity of ursolic acid, a triterpenoid antioxidant, is mediated through suppression of NF- $\mathrm{KB}, \mathrm{AP}-1$ and NF-AT. PLoS ONE 2012, 7, e31318. [CrossRef] [PubMed]

188. Ma, D.; Fang, Q.; Li, Y.; Wang, J.; Sun, J.; Zhang, Y.; Hu, X.; Wang, P.; Zhou, S. Crucial role of heme oxygenase-1 in the sensitivity of acute myeloid leukemia cell line Kasumi-1 to ursolic acid. Anti-Cancer Drugs 2014, 25, 406-414. [CrossRef]

189. Subbaramaiah, K.; Michaluart, P.; Sporn, M.B.; Dannenberg, A.J. Ursolic acid inhibits cyclooxygenase-2 transcription in human mammary epithelial cells. Cancer Res. 2000, 60, 2399-2404.

190. Liu, L.; Zhang, J.; Li, M.; Zhang, X.; Zhang, J.; Li, Z.; Wang, L.; Wu, J.; Luo, C. Inhibition of HepG2 cell proliferation by ursolic acid and polysaccharides via the downregulation of cyclooxygenase-2. Mol. Med. Rep. 2014, 9, 2505-2511. [CrossRef] [PubMed]

191. Zhang, H.; Li, X.; Ding, J.; Xu, H.; Dai, X.; Hou, Z.; Zhang, K.; Sun, K.; Sun, W. Delivery of ursolic acid (UA) in polymeric nanoparticles effectively promotes the apoptosis of gastric cancer cells through enhanced inhibition of cyclooxygenase 2 (COX-2). Int. J. Pharm. 2013, 441, 261-268. [CrossRef] [PubMed]

192. Wang, C.; Shu, L.; Zhang, C.; Li, W.; Wu, R.; Guo, Y.; Yang, Y.; Kong, A.N. Histone methyltransferase Setd7 regulates Nrf2 signaling pathway by phenethyl isothiocyanate and ursolic acid in human prostate cancer cells. Mol. Nutr. Food Res. 2018, 62, 1700840. [CrossRef]

193. Zhang, X.; Li, T.; Gong, E.S.; Liu, R.H. Antiproliferative Activity of Ursolic Acid in MDA-MB-231 Human Breast Cancer Cells through Nrf2 Pathway Regulation. J. Agric. Food Chem. 2020, 68, 7404-7415. [CrossRef]

194. Yeh, C.T.; Wu, C.H.; Yen, G.C. Ursolic acid, a naturally occurring triterpenoid, suppresses migration and invasion of human breast cancer cells by modulating c-Jun N-terminal kinase, Akt and mammalian target of rapamycin signaling. Mol. Nutr. Food Res. 2010, 54, 1285-1295. [CrossRef]

195. Wu, S.; Zhang, T.; Du, J. Ursolic acid sensitizes cisplatin-resistant HepG2/DDP cells to cisplatin via inhibiting Nrf2/ARE pathway. Drug Des. Dev. Ther. 2016, 10, 3471. [CrossRef] [PubMed]

196. Kim, K.; Shin, E.A.; Jung, J.H.; Park, J.E.; Kim, D.S.; Shim, B.S.; Kim, S.-H. Ursolic acid induces apoptosis in colorectal cancer cells partially via upregulation of MicroRNA-4500 and inhibition of JAK2/STAT3 phosphorylation. Int. J. Mol. Sci. 2019, 20, 114. [CrossRef]

197. Wang, S.; Meng, X.; Dong, Y. Ursolic acid nanoparticles inhibit cervical cancer growth in vitro and in vivo via apoptosis induction. Int. J. Oncol. 2017, 50, 1330-1340. [CrossRef] [PubMed]

198. Ma, J.-Q.; Ding, J.; Zhang, L.; Liu, C.-M. Protective effects of ursolic acid in an experimental model of liver fibrosis through Nrf2/ARE pathway. Clin. Res. Hepatol. Gastroenterol. 2015, 39, 188-197. [CrossRef] [PubMed]

199. Zhang, C.; Wang, C.; Li, W.; Wu, R.; Guo, Y.; Cheng, D.; Yang, Y.; Androulakis, I.P.; Kong, A.-N. Pharmacokinetics and pharmacodynamics of the triterpenoid ursolic acid in regulating the antioxidant, anti-inflammatory, and epigenetic gene responses in rat leukocytes. Mol. Pharm. 2017, 14, 3709-3717. [CrossRef] [PubMed]

200. Ramirez, C.N.; Li, W.; Zhang, C.; Wu, R.; Su, S.; Wang, C.; Gao, L.; Yin, R.; Kong, A.-N. In vitro-in vivo dose response of ursolic acid, sulforaphane, PEITC, and curcumin in cancer prevention. AAPS J. 2018, 20, 1-19.

201. Li, W.; Sun, K.; Hu, F.; Chen, L.; Zhang, X.; Wang, F.; Yan, B. Protective effects of natural compounds against oxidative stress in ischemic diseases and cancers via activating the Nrf2 signaling pathway: A mini review. J. Biochem. Mol. Toxicol. 2021, 35, e22658. [CrossRef]

202. Kim, H.; Ramirez, C.N.; Su, Z.-Y.; Kong, A.-N.T. Epigenetic modifications of triterpenoid ursolic acid in activating Nrf2 and blocking cellular transformation of mouse epidermal cells. J. Nutr. Biochem. 2016, 33, 54-62. [CrossRef]

203. Ramirez, C.N. Epigenetic Regulation of Nrf2 and Ursolic Acid in Skin Carcinogenesis; Rutgers University-School of Graduate Studies: New Brunswick, NJ, USA, 2018.

204. Liu, W.; Tan, X.; Shu, L.; Sun, H.; Song, J.; Jin, P.; Yu, S.; Sun, M.; Jia, X. Ursolic acid inhibits cigarette smoke extract-induced human bronchial epithelial cell injury and prevents development of lung cancer. Molecules 2012, 17, 9104-9115. [CrossRef]

205. Yang, Y.; Yin, R.; Wu, R.; Ramirez, C.N.; Sargsyan, D.; Li, S.; Wang, L.; Cheng, D.; Wang, C.; Hudlikar, R. DNA methylome and transcriptome alterations and cancer prevention by triterpenoid ursolic acid in UVB-induced skin tumor in mice. Mol. Carcinog. 2019, 58, 1738-1753. [CrossRef]

206. Tao, X.; Xu, L.; Yin, L.; Han, X.; Qi, Y.; Xu, Y.; Song, S.; Zhao, Y.; Peng, J. Dioscin induces prostate cancer cell apoptosis through activation of estrogen receptor- $\beta$. Cell Death Dis. 2017, 8, e2989. [CrossRef]

207. Mao, W.; Yin, H.; Chen, W.; Zhao, T.; Wu, S.; Jin, H.; Du, B.; Tan, Y.; Zhang, R.; He, Y. Network pharmacology and experimental evidence reveal dioscin suppresses proliferation, invasion, and EMT via AKT/GSK3b/mTOR signaling in lung adenocarcinoma. Drug Des. Dev. Ther. 2020, 14, 2135. [CrossRef]

208. Ma, T.; Wang, R.-P.; Zou, X. Dioscin inhibits gastric tumor growth through regulating the expression level of lncRNA HOTAIR. BMC Complement. Altern. Med. 2016, 16, 1-6. [CrossRef]

209. Wang, P.; Wang, C.; Liu, C. Antitumor effects of dioscin in A431 cells via adjusting ATM/p53-mediated cell apoptosis, DNA damage and migration. Oncol. Lett. 2021, 21, 59. [CrossRef] [PubMed]

210. Wang, Y.; He, Q.-Y.; Chiu, J.-F. Dioscin induced activation of p38 MAPK and JNK via mitochondrial pathway in HL-60 cell line. Eur. J. Pharmacol. 2014, 735, 52-58. [CrossRef] 
211. Ran, X.; Yan, Z.; Yang, Y.; Hu, G.; Liu, J.; Hou, S.; Guo, W.; Kan, X.; Fu, S. Dioscin Improves Pyroptosis in LPS-Induced Mice Mastitis by Activating AMPK/Nrf2 and Inhibiting the NF-kB Signaling Pathway. Oxid. Med. Cell. Longev. 2020, $2020,8845521$. [CrossRef]

212. Zhiyu, W.; Yue, C.; Neng, W.; Mei, W.D.; Wei, L.Y.; Feng, H.; Gang, S.J.; De Po, Y.; Yuan, G.X.; Jian-Ping, C. Dioscin induces cancer cell apoptosis through elevated oxidative stress mediated by downregulation of peroxiredoxins. Cancer Biol. Ther. 2012, 13, 138-147. [CrossRef] [PubMed]

213. Wang, Y.; Yu, R.-Y.; Zhang, J.; Zhang, W.-X.; Huang, Z.-H.; Hu, H.-F.; Li, Y.-L.; Li, B.; He, Q.-Y. Inhibition of Nrf2 enhances the anticancer effect of 6-O-angeloylenolin in lung adenocarcinoma. Biochem. Pharmacol. 2017, 129, 43-53. [CrossRef] [PubMed]

214. Li, S.; Cheng, B.; Hou, L.; Huang, L.; Cui, Y.; Xu, D.; Shen, X.; Li, S. Dioscin inhibits colon cancer cells' growth by reactive oxygen species-mediated mitochondrial dysfunction and p38 and JNK pathways. Anti-Cancer Drugs 2018, 29, 234-242. [CrossRef]

215. Hsieh, M.-J.; Yang, S.-F.; Hsieh, Y.-S.; Chen, T.-Y.; Chiou, H.-L. Autophagy inhibition enhances apoptosis induced by dioscin in huh7 cells. Evid.-Based Complement. Altern. Med. 2012, 2012, 134512. [CrossRef]

216. Lim, W.-C.; Kim, H.; Kim, Y.-J.; Choi, K.-C.; Lee, I.H.; Lee, K.H.; Kim, M.K.; Ko, H. Dioscin suppresses TGF- $\beta 1$-induced epithelialmesenchymal transition and suppresses A549 lung cancer migration and invasion. Bioorg. Med. Chem. Lett. 2017, 27, 3342-3348. [CrossRef]

217. Gu, L.; Tao, X.; Xu, Y.; Han, X.; Qi, Y.; Xu, L.; Yin, L.; Peng, J. Dioscin alleviates BDL-and DMN-induced hepatic fibrosis via Sirt1/Nrf2-mediated inhibition of p38 MAPK pathway. Toxicol. Appl. Pharmacol. 2016, 292, 19-29. [CrossRef] [PubMed]

218. Song, S.; Chu, L.; Liang, H.; Chen, J.; Liang, J.; Huang, Z.; Zhang, B.; Chen, X. Protective effects of dioscin against doxorubicininduced hepatotoxicity via regulation of Sirt1/FOXO1/NF-kb signal. Front. Pharmacol. 2019, 10, 1030. [CrossRef]

219. Wu, Z.-L.; Wang, J. Dioscin attenuates Bleomycin-Induced acute lung injury via inhibiting the inflammatory response in mice. Exp. Lung Res. 2019, 45, 236-244. [CrossRef]

220. Wang, C.; Li, Q.; Li, T. Dioscin alleviates lipopolysaccharide-induced acute lung injury through suppression of TLR4 signaling pathways. Exp. Lung Res. 2020, 46, 11-22. [CrossRef]

221. Li, Y.; Gao, M.; Yin, L.-H.; Xu, L.-N.; Qi, Y.; Sun, P.; Peng, J.-Y. Dioscin ameliorates methotrexate-induced liver and kidney damages via adjusting miRNA-145-5p-mediated oxidative stress. Free Radic. Biol. Med. 2021, 169, 99-109. [CrossRef] [PubMed]

222. Zheng, L.; Yin, L.; Xu, L.; Qi, Y.; Li, H.; Xu, Y.; Han, X.; Liu, K.; Peng, J. Protective effect of dioscin against thioacetamide-induced acute liver injury via FXR/AMPK signaling pathway in vivo. Biomed. Pharmacother. 2018, 97, 481-488. [CrossRef]

223. Zhang, W.; Yin, L.; Tao, X.; Xu, L.; Zheng, L.; Han, X.; Xu, Y.; Wang, C.; Peng, J. Dioscin alleviates dimethylnitrosamine-induced acute liver injury through regulating apoptosis, oxidative stress and inflammation. Environ. Toxicol. Pharmacol. 2016, 45, 193-201. [CrossRef]

224. Zhang, X.; Xu, Y.; Qi, Y.; Han, X.; Yin, L.; Xu, L.; Liu, K.; Peng, J. Potent effects of dioscin against thioacetamide-induced liver fibrosis through attenuating oxidative stress in turn inhibiting inflammation, TGF- $\beta$ /Smad and MAPK signaling pathways. J. Funct. Foods 2015, 16, 436-447. [CrossRef]

225. Zhang, X.; Han, X.; Yin, L.; Xu, L.; Qi, Y.; Xu, Y.; Sun, H.; Lin, Y.; Liu, K.; Peng, J. Potent effects of dioscin against liver fibrosis. Sci. Rep. 2015, 5, 9713. [CrossRef]

226. Yao, H.; Sun, Y.; Song, S.; Qi, Y.; Tao, X.; Xu, L.; Yin, L.; Han, X.; Xu, Y.; Li, H. Protective effects of dioscin against lipopolysaccharideinduced acute lung injury through inhibition of oxidative stress and inflammation. Front. Pharmacol. 2017, 8, 120. [CrossRef] [PubMed]

227. Hsieh, M.-J.; Tsai, T.-L.; Hsieh, Y.-S.; Wang, C.-J.; Chiou, H.-L. Dioscin-induced autophagy mitigates cell apoptosis through modulation of PI3K/Akt and ERK and JNK signaling pathways in human lung cancer cell lines. Arch. Toxicol. 2013, 87, 1927-1937. [CrossRef] [PubMed]

228. Cui, A.; Li, X.; Ma, X.; Wang, X.; Liu, C.; Song, Z.; Pan, F.; Xia, Y.; Li, C. Transcriptome and Proteome Analysis Reveals Corosolic Acid Inhibiting Bladder Cancer via Targeting Cell Cycle and Inducing Mitophagy In Vitro and In Vivo; Research Square: Durham, NC, USA, 2021.

229. Zhang, B.Y.; Zhang, L.; Chen, Y.M.; Qiao, X.; Zhao, S.L.; Li, P.; Liu, J.F.; Wen, X.; Yang, J. Corosolic acid inhibits colorectal cancer cells growth as a novel HER2/HER3 heterodimerization inhibitor. Br. J. Pharmacol. 2021, 178, 1475-1491. [CrossRef]

230. Jia, M.; Xiong, Y.; Li, M.; Mao, Q. Corosolic acid inhibits cancer progress through inactivating YAP in hepatocellular carcinoma. Oncol. Res. 2020, 28, 371. [CrossRef] [PubMed]

231. Son, K.H.; Hwang, J.-H.; Kim, D.-H.; Cho, Y.-E. Effect of corosolic acid on apoptosis and angiogenesis in MDA-MB-231 human breast cancer cells. J. Nutr. Health 2020, 53, 111-120. [CrossRef]

232. Jin, M.; Wu, Y.; Lou, Y.; Liu, X.; Dai, Y.; Yang, W.; Liu, C.; Huang, G. Corosolic Acid Reduces NSCLC Cell Proliferation, Invasion, and Chemoresistance via Inducing Mitochondrial and Liposomal Oxidative Stress; Research Square: Durham, NC, USA, 2021.

233. Yang, J.; Wu, R.; Li, W.; Gao, L.; Yang, Y.; Li, P.; Kong, A.N. The triterpenoid corosolic acid blocks transformation and epigenetically reactivates Nrf2 in TRAMP-C1 prostate cells. Mol. Carcinog. 2018, 57, 512-521. [CrossRef]

234. Guo, Y.; Su, Z.-Y.; Kong, A.-N.T. Current perspectives on epigenetic modifications by dietary chemopreventive and herbal phytochemicals. Curr. Pharmacol. Rep. 2015, 1, 245-257. [CrossRef]

235. Chen, Z.; Wang, L.; Wang, Q.; Li, W. Histone modifications and chromatin organization in prostate cancer. Epigenomics 2010, 2, 551-560. [CrossRef] [PubMed] 
236. Horlad, H.; Fujiwara, Y.; Takemura, K.; Ohnishi, K.; Ikeda, T.; Tsukamoto, H.; Mizuta, H.; Nishimura, Y.; Takeya, M.; Komohara, Y. Corosolic acid impairs tumor development and lung metastasis by inhibiting the immunosuppressive activity of myeloid-derived suppressor cells. Mol. Nutr. Food Res. 2013, 57, 1046-1054. [CrossRef] [PubMed]

237. Fujiwara, Y.; Komohara, Y.; Ikeda, T.; Takeya, M. Corosolic acid inhibits glioblastoma cell proliferation by suppressing the activation of signal transducer and activator of transcription-3 and nuclear factor-kappa B in tumor cells and tumor-associated macrophages. Cancer Sci. 2011, 102, 206-211. [CrossRef]

238. Xu, Y.Q.; Zhang, J.H.; Yang, X.S. Corosolic acid induces potent anti-cancer effects in CaSki cervical cancer cells through the induction of apoptosis, cell cycle arrest and PI3K/Akt signalling pathway. Bangladesh J. Pharmacol. 2016, 11, 453-459. [CrossRef]

239. Zhao, J.; Zhou, H.; An, Y.; Shen, K.; Yu, L. Biological effects of corosolic acid as an anti-inflammatory, anti-metabolic syndrome and anti-neoplasic natural compound. Oncol. Lett. 2021, 21, 84. [CrossRef]

240. Peng, M.; Qiang, L.; Xu, Y.; Li, C.; Li, T.; Wang, J. Inhibition of JNK and activation of the AMPK-Nrf2 axis by corosolic acid suppress osteolysis and oxidative stress. Nitric Oxide 2019, 82, 12-24. [CrossRef] [PubMed]

241. Kim, S.-J.; Cha, J.-Y.; Kang, H.S.; Lee, J.-H.; Lee, J.Y.; Park, J.-H.; Bae, J.-H.; Song, D.-K.; Im, S.-S. Corosolic acid ameliorates acute inflammation through inhibition of IRAK-1 phosphorylation in macrophages. BMB Rep. 2016, 49, 276. [CrossRef]

242. Palozza, P.; Catalano, A.; Simone, R.; Cittadini, A. Lycopene as a guardian of redox signalling. Acta Biochim. Pol. 2012, 59. [CrossRef]

243. Mirahmadi, M.; Azimi-Hashemi, S.; Saburi, E.; Kamali, H.; Pishbin, M.; Hadizadeh, F. Potential inhibitory effect of lycopene on prostate cancer. Biomed. Pharmacother. 2020, 129, 110459. [CrossRef] [PubMed]

244. Gong, X.; Marisiddiah, R.; Wiener, D.; Rubin, L.P. Regulation of Antioxidant Responses in Prostate Cancer: Nrf2-Dependent and Independent Effects of Lycopene; Wiley Online Library: Hoboken, NJ, USA, 2012.

245. Marisiddaiah, R.; Gong, X.; Wiener, D.; Rubin, L.P. Lycopene Alters Intracellular Glutathione Status and Antioxidant/Phase II Detoxifying Enzymes in Human Prostate Cancer Cells; Wiley Online Library: Hoboken, NJ, USA, 2011.

246. Li, D.; Chen, L.; Zhao, W.; Hao, J.; An, R. MicroRNA-let-7f-1 is induced by lycopene and inhibits cell proliferation and triggers apoptosis in prostate cancer. Mol. Med. Rep. 2016, 13, 2708-2714. [CrossRef] [PubMed]

247. Assar, E.A.; Vidalle, M.C.; Chopra, M.; Hafizi, S. Lycopene acts through inhibition of IкB kinase to suppress NF- $\mathrm{B}$ signaling in human prostate and breast cancer cells. Tumor Biol. 2016, 37, 9375-9385. [CrossRef]

248. Aktepe, O.H.; Şahin, T.K.; Güner, G.; Arik, Z.; Yalçin, Ş. Lycopene sensitizes the cervical cancer cells to cisplatin via targeting nuclear factorkappa B (NF-kB) pathway. Turk. J. Med. Sci. 2021, 51, 368-374. [CrossRef] [PubMed]

249. Lin, M.-C.; Wang, F.-Y.; Kuo, Y.-H.; Tang, F.-Y. Cancer chemopreventive effects of lycopene: Suppression of MMP-7 expression and cell invasion in human colon cancer cells. J. Agric. Food Chem. 2011, 59, 11304-11318. [CrossRef] [PubMed]

250. Takeshima, M.; Ono, M.; Higuchi, T.; Chen, C.; Hara, T.; Nakano, S. Anti-proliferative and apoptosis-inducing activity of lycopene against three subtypes of human breast cancer cell lines. Cancer Sci. 2014, 105, 252-257. [CrossRef]

251. Yang, P.-M.; Chen, H.-Z.; Huang, Y.-T.; Hsieh, C.-W.; Wung, B.-S. Lycopene inhibits NF-kB activation and adhesion molecule expression through Nrf2-mediated heme oxygenase-1 in endothelial cells. Int. J. Mol. Med. 2017, 39, 1533-1540. [CrossRef] [PubMed]

252. Cha, J.H.; Kim, W.K.; Ha, A.W.; Kim, M.H.; Chang, M.J. Anti-inflammatory effect of lycopene in SW480 human colorectal cancer cells. Nutr. Res. Pract. 2017, 11, 90-96. [CrossRef] [PubMed]

253. Jiang, L.-N.; Liu, Y.-B.; Li, B.-H. Lycopene exerts anti-inflammatory effect to inhibit prostate cancer progression. Asian J. Androl. 2019, 21, 80 .

254. Yang, P.-M.; Wu, Z.-Z.; Zhang, Y.-Q.; Wung, B.-S. Lycopene inhibits ICAM-1 expression and NF-kB activation by Nrf2-regulated cell redox state in human retinal pigment epithelial cells. Life Sci. 2016, 155, 94-101. [CrossRef]

255. Sahin, K.; Yenice, E.; Tuzcu, M.; Orhan, C.; Mizrak, C.; Ozercan, I.H.; Sahin, N.; Yilmaz, B.; Bilir, B.; Ozpolat, B. Lycopene protects against spontaneous ovarian cancer formation in laying hens. J. Cancer Prev. 2018, 23, 25. [CrossRef] [PubMed]

256. Wang, Y.; Ausman, L.M.; Greenberg, A.S.; Russell, R.M.; Wang, X.D. Dietary lycopene and tomato extract supplementations inhibit nonalcoholic steatohepatitis-promoted hepatocarcinogenesis in rats. Int. J. Cancer 2010, 126, 1788-1796. [CrossRef]

257. Sahin, K.; Orhan, C.; Tuzcu, M.; Sahin, N.; Ali, S.; Bahcecioglu, I.H.; Guler, O.; Ozercan, I.; Ilhan, N.; Kucuk, O. Orally administered lycopene attenuates diethylnitrosamine-induced hepatocarcinogenesis in rats by modulating Nrf-2/HO-1 and Akt/mTOR pathways. Nutr. Cancer 2014, 66, 590-598. [CrossRef]

258. Wang, S.; Wu, Y.-Y.; Wang, X.; Shen, P.; Jia, Q.; Yu, S.; Wang, Y.; Li, X.; Chen, W.; Wang, A. Lycopene prevents carcinogen-induced cutaneous tumor by enhancing activation of the Nrf2 pathway through p62-triggered autophagic Keap1 degradation. Aging 2020, 12, 8167. [CrossRef]

259. Shen, C.; Wang, S.; Shan, Y.; Liu, Z.; Fan, F.; Tao, L.; Liu, Y.; Zhou, L.; Pei, C.; Wu, H. Chemomodulatory efficacy of lycopene on antioxidant enzymes and carcinogen-induced cutaneum carcinoma in mice. Food Funct. 2014, 5, 1422-1431. [CrossRef]

260. Saini, R.K.; Rengasamy, K.R.; Mahomoodally, F.M.; Keum, Y.-S. Protective effects of lycopene in cancer, cardiovascular, and neurodegenerative diseases: An update on epidemiological and mechanistic perspectives. Pharmacol. Res. 2020, $155,104730$. [CrossRef]

261. Puah, B.-P.; Jalil, J.; Attiq, A.; Kamisah, Y. New Insights into Molecular Mechanism behind Anti-Cancer Activities of Lycopene. Molecules 2021, 26, 3888. [CrossRef] 
262. Zhao, Q.; Yang, F.; Meng, L.; Chen, D.; Wang, M.; Lu, X.; Chen, D.; Jiang, Y.; Xing, N. Lycopene attenuates chronic prostatitis/chronic pelvic pain syndrome by inhibiting oxidative stress and inflammation via the interaction of NF- $\mathrm{kB}, \mathrm{MAPKs}$, and Nrf2 signaling pathways in rats. Andrology 2020, 8, 747-755. [CrossRef] [PubMed]

263. Xu, F.; Yu, K.; Yu, H.; Wang, P.; Song, M.; Xiu, C.; Li, Y. Lycopene relieves AFB1-induced liver injury through enhancing hepatic antioxidation and detoxification potential with Nrf2 activation. J. Funct. Foods 2017, 39, 215-224. [CrossRef]

264. Dong, J.; Li, W.; Cheng, L.-M.; Wang, G.-G. Lycopene attenuates LPS-induced liver injury by inactivation of NF- $\mathrm{kB} / \mathrm{COX}-2$ signaling. Int. J. Clin. Exp. Pathol. 2019, 12, 817. [PubMed]

265. Akdemir, B.; Bahcecioglu, I.H.; Tuzcu, M.; Orhan, C.; Ispiroglu, M.; Ozercan, I.H.; Ilhan, N.; Celik, N.C.; Sahin, K. Effect of lycopene and genistein on hepatic inflammation and fibrosis in thioacetamide induced liver injury in rats. J. Adv. Med. Med. Res. 2016, 1-11. [CrossRef]

266. Fassett, R.G.; Coombes, J.S. Astaxanthin in cardiovascular health and disease. Molecules 2012, 17, 2030-2048. [CrossRef] [PubMed]

267. Yang, Y.; Kim, B.; Lee, J.Y. Astaxanthin structure, metabolism, and health benefits. J. Hum. Nutr. Food Sci. $2013,1,1-1003$.

268. Farruggia, C.; Kim, M.-B.; Bae, M.; Lee, Y.; Pham, T.X.; Yang, Y.; Han, M.J.; Park, Y.-K.; Lee, J.-Y. Astaxanthin exerts antiinflammatory and antioxidant effects in macrophages in NRF2-dependent and independent manners. J. Nutr. Biochem. 2018, 62, 202-209. [CrossRef]

269. Kohandel, Z.; Farkhondeh, T.; Aschner, M.; Samarghandian, S. Nrf2 a molecular therapeutic target for Astaxanthin. Biomed. Pharmacother. 2021, 137, 111374. [CrossRef] [PubMed]

270. Cheng, J.; Eroglu, A. The Promising Effects of Astaxanthin on Lung Diseases. Adv. Nutr. 2021, 12, 850-864. [CrossRef] [PubMed]

271. Faraone, I.; Sinisgalli, C.; Ostuni, A.; Armentano, M.F.; Carmosino, M.; Milella, L.; Russo, D.; Labanca, F.; Khan, H. Astaxanthin anticancer effects are mediated through multiple molecular mechanisms: A systematic review. Pharmacol. Res. 2020, 155, 104689. [CrossRef]

272. Zhang, X.; Zhao, W.-E.; Hu, L.; Zhao, L.; Huang, J. Carotenoids inhibit proliferation and regulate expression of peroxisome proliferators-activated receptor gamma (PPAR $\gamma)$ in K562 cancer cells. Arch. Biochem. Biophys. 2011, 512, 96-106. [CrossRef] [PubMed]

273. Franceschelli, S.; Pesce, M.; Ferrone, A.; De Lutiis, M.A.; Patruno, A.; Grilli, A.; Felaco, M.; Speranza, L. Astaxanthin treatment confers protection against oxidative stress in U937 cells stimulated with lipopolysaccharide reducing $\mathrm{O}_{2}{ }^{-}$production. PLoS ONE 2014, 9, e88359.

274. Zhou, Y.; Baker, J.S.; Chen, X.; Wang, Y.; Chen, H.; Davison, G.W.; Yan, X. High-dose astaxanthin supplementation suppresses antioxidant enzyme activity during moderate-intensity swimming training in mice. Nutrients 2019, 11, 1244. [CrossRef]

275. Yang, Y.; Fuentes, F.; Shu, L.; Wang, C.; Pung, D.; Li, W.; Zhang, C.; Guo, Y.; Kong, A.-N. Epigenetic CpG methylation of the promoter and reactivation of the expression of GSTP1 by Astaxanthin in human prostate LNCaP cells. AAPS J. 2017, 19, 421-430. [CrossRef] [PubMed]

276. Li, J.; Dai, W.; Xia, Y.; Chen, K.; Li, S.; Liu, T.; Zhang, R.; Wang, J.; Lu, W.; Zhou, Y. Astaxanthin inhibits proliferation and induces apoptosis of human hepatocellular carcinoma cells via Inhibition of NF-kB P65 and Wnt/ $\beta$-catenin in vitro. Mar. Drugs 2015, 13, 6064-6081. [CrossRef]

277. Kavitha, K.; Kowshik, J.; Kishore, T.K.K.; Baba, A.B.; Nagini, S. Astaxanthin inhibits NF-кB and Wnt/ $\beta$-catenin signaling pathways via inactivation of Erk/MAPK and PI3K/Akt to induce intrinsic apoptosis in a hamster model of oral cancer. Biochim. Biophys. Acta (BBA)-Gen. Subj. 2013, 1830, 4433-4444. [CrossRef]

278. Palozza, P.; Torelli, C.; Boninsegna, A.; Simone, R.; Catalano, A.; Mele, M.C.; Picci, N. Growth-inhibitory effects of the astaxanthinrich alga Haematococcus pluvialis in human colon cancer cells. Cancer Lett. 2009, 283, 108-117. [CrossRef]

279. Niu, T.; Xuan, R.; Jiang, L.; Wu, W.; Zhen, Z.; Song, Y.; Hong, L.; Zheng, K.; Zhang, J.; Xu, Q. Astaxanthin induces the Nrf2/HO-1 antioxidant pathway in human umbilical vein endothelial cells by generating trace amounts of ROS. J. Agric. Food Chem. 2018, 66, 1551-1559. [CrossRef]

280. Zuluaga, M.; Barzegari, A.; Letourneur, D.; Gueguen, V.; Pavon-Djavid, G. Oxidative stress regulation on endothelial cells by hydrophilic astaxanthin complex: Chemical, biological, and molecular antioxidant activity evaluation. Oxid. Med. Cell. Longev. 2017, 2017, 8073798. [CrossRef]

281. Saw, C.L.L.; Yang, A.Y.; Guo, Y.; Kong, A.-N.T. Astaxanthin and omega-3 fatty acids individually and in combination protect against oxidative stress via the Nrf2-ARE pathway. Food Chem. Toxicol. 2013, 62, 869-875. [CrossRef]

282. Su, X.-Z.; Chen, R.; Wang, C.-B.; Ouyang, X.-L.; Jiang, Y.; Zhu, M.-Y. Astaxanthin combine with human serum albumin to abrogate cell proliferation, migration, and drug-resistant in human ovarian carcinoma SKOV3 cells. Anti-Cancer Agents Med. Chem. (Former. Curr. Med. Chem.-Anti-Cancer Agents) 2019, 19, 792-801. [CrossRef]

283. Jeong, S.M.; Kim, Y.-J. Astaxanthin treatment induces maturation and functional change of myeloid-derived suppressor cells in tumor-bearing mice. Antioxidants 2020, 9, 350. [CrossRef] [PubMed]

284. Cui, L.; Xu, F.; Wang, M.; Li, L.; Qiao, T.; Cui, H.; Li, Z.; Sun, C. Dietary natural astaxanthin at an early stage inhibits Nnitrosomethylbenzylamine-induced esophageal cancer oxidative stress and inflammation via downregulation of NFKB and COX2 in F344 rats. OncoTargets Ther. 2019, 12, 5087. [CrossRef] [PubMed]

285. Tripathi, D.; Jena, G. Astaxanthin intervention ameliorates cyclophosphamide-induced oxidative stress, DNA damage and early hepatocarcinogenesis in rat: Role of Nrf2, p53, p38 and phase-II enzymes. Mutat. Res./Genet. Toxicol. Environ. Mutagen. 2010, 696, 69-80. [CrossRef] 
286. Heng, N.; Gao, S.; Chen, Y.; Wang, L.; Li, Z.; Guo, Y.; Sheng, X.; Wang, X.; Xing, K.; Xiao, L. Dietary supplementation with natural astaxanthin from Haematococcus pluvialis improves antioxidant enzyme activity, free radical scavenging ability, and gene expression of antioxidant enzymes in laying hens. Poult. Sci. 2021, 100, 101045. [CrossRef]

287. Nagendraprabhu, P.; Sudhandiran, G. Astaxanthin inhibits tumor invasion by decreasing extracellular matrix production and induces apoptosis in experimental rat colon carcinogenesis by modulating the expressions of ERK-2, NFkB and COX-2. Investig. New Drugs 2011, 29, 207-224. [CrossRef] [PubMed]

288. Kowshik, J.; Baba, A.B.; Giri, H.; Reddy, G.D.; Dixit, M.; Nagini, S. Astaxanthin inhibits JAK/STAT-3 signaling to abrogate cell proliferation, invasion and angiogenesis in a hamster model of oral cancer. PLoS ONE 2014, 9, e109114. [CrossRef]

289. Ma, H.; Chen, S.; Xiong, H.; Wang, M.; Hang, W.; Zhu, X.; Zheng, Y.; Ge, B.; Li, R.; Cui, H. Astaxanthin from Haematococcus pluvialis ameliorates the chemotherapeutic drug (doxorubicin) induced liver injury through the Keap1/Nrf2/HO-1 pathway in mice. Food Funct. 2020, 11, 4659-4671. [CrossRef] [PubMed]

290. Xu, W.; Wang, M.; Cui, G.; Li, L.; Jiao, D.; Yao, B.; Xu, K.; Chen, Y.; Long, M.; Yang, S. Astaxanthin protects OTA-induced lung injury in mice through the Nrf2/NF-kB pathway. Toxins 2019, 11, 540. [CrossRef]

291. Wu, H.; Niu, H.; Shao, A.; Wu, C.; Dixon, B.J.; Zhang, J.; Yang, S.; Wang, Y. Astaxanthin as a potential neuroprotective agent for neurological diseases. Mar. Drugs 2015, 13, 5750-5766. [CrossRef] [PubMed]

292. Kim, M.-B.; Kang, H.; Li, Y.; Park, Y.-K.; Lee, J.-Y. Fucoxanthin inhibits lipopolysaccharide-induced inflammation and oxidative stress by activating nuclear factor E2-related factor 2 via the phosphatidylinositol 3-kinase/AKT pathway in macrophages. Eur. J. Nutr. 2021, 60, 3315-3324. [CrossRef]

293. Yang, Y.; Yang, I.; Cao, M.; Su, Z.-y.; Wu, R.; Guo, Y.; Fang, M.; Kong, A.-N. Fucoxanthin elicits epigenetic modifications, Nrf2 activation and blocking transformation in mouse skin JB6 P+ cells. AAPS J. 2018, 20, 32. [CrossRef] [PubMed]

294. Liu, C.-L.; Chiu, Y.-T.; Hu, M.-L. Fucoxanthin enhances HO-1 and NQO1 expression in murine hepatic BNL CL. 2 cells through activation of the Nrf2/ARE system partially by its pro-oxidant activity. J. Agric. Food Chem. 2011, 59, 11344-11351. [CrossRef]

295. Foo, S.C.; Yusoff, F.M.; Imam, M.U.; Foo, J.B.; Ismail, N.; Azmi, N.H.; Tor, Y.S.; Khong, N.M.; Ismail, M. Increased fucoxanthin in Chaetoceros calcitrans extract exacerbates apoptosis in liver cancer cells via multiple targeted cellular pathways. Biotechnol. Rep. 2019, 21, e00296. [CrossRef] [PubMed]

296. Wang, X.; Cui, Y.-J.; Qi, J.; Zhu, M.-M.; Zhang, T.-L.; Cheng, M.; Liu, S.-M.; Wang, G.-C. Fucoxanthin exerts cytoprotective effects against hydrogen peroxide-induced oxidative damage in L02 cells. BioMed Res. Int. 2018, 2018, 1085073. [CrossRef]

297. Rodríguez-Luna, A.; Ávila-Román, J.; Oliveira, H.; Motilva, V.; Talero, E. Fucoxanthin and rosmarinic acid combination has anti-inflammatory effects through regulation of NLRP3 inflammasome in UVB-exposed HaCaT keratinocytes. Mar. Drugs 2019, 17, 451. [CrossRef]

298. Zheng, J.; Piao, M.J.; Kim, K.C.; Yao, C.W.; Cha, J.W.; Hyun, J.W. Fucoxanthin enhances the level of reduced glutathione via the Nrf2-mediated pathway in human keratinocytes. Mar. Drugs 2014, 12, 4214-4230. [CrossRef]

299. Liu, C.-L.; Lim, Y.-P.; Hu, M.-L. Fucoxanthin enhances cisplatin-induced cytotoxicity via NFkB-mediated pathway and downregulates DNA repair gene expression in human hepatoma HepG2 cells. Mar. Drugs 2013, 11, 50-66. [CrossRef]

300. Ha, A.W.; Na, S.J.; Kim, W.K. Antioxidant effects of fucoxanthin rich powder in rats fed with high fat diet. Nutr. Res. Pract. 2013, 7, 475-480. [CrossRef] [PubMed]

301. Zheng, J.; Tian, X.; Zhang, W.; Zheng, P.; Huang, F.; Ding, G.; Yang, Z. Protective effects of fucoxanthin against alcoholic liver injury by activation of Nrf2-mediated antioxidant defense and inhibition of TLR4-mediated inflammation. Mar. Drugs 2019, 17, 552. [CrossRef] [PubMed]

302. Chen, S.-J.; Lin, T.-B.; Peng, H.-Y.; Lin, C.-H.; Lee, A.-S.; Liu, H.-J.; Li, C.-C.; Tseng, K.-W. Protective Effects of Fucoxanthin Dampen Pathogen-Associated Molecular Pattern (PAMP) Lipopolysaccharide-Induced Inflammatory Action and Elevated Intraocular Pressure by Activating Nrf2 Signaling and Generating Reactive Oxygen Species. Antioxidants 2021, 10, 1092. [CrossRef] [PubMed]

303. Liu, M.; Li, W.; Chen, Y.; Wan, X.; Wang, J. Fucoxanthin: A promising compound for human inflammation-related diseases. Life Sci. 2020, 255, 117850. [CrossRef] [PubMed] 